University of Louisville

ThinkIR: The University of Louisville's Institutional Repository

$12-2013$

\title{
Community level impacts of Microstegium vimineum on arthropod community structure and foodweb dynamics in a temperate deciduous forest.
}

Judith L. Metcalf

University of Louisville

Follow this and additional works at: https://ir.library.louisville.edu/etd

\section{Recommended Citation}

Metcalf, Judith L., "Community level impacts of Microstegium vimineum on arthropod community structure and foodweb dynamics in a temperate deciduous forest." (2013). Electronic Theses and Dissertations. Paper 966.

https://doi.org/10.18297/etd/966

This Doctoral Dissertation is brought to you for free and open access by ThinkIR: The University of Louisville's Institutional Repository. It has been accepted for inclusion in Electronic Theses and Dissertations by an authorized administrator of ThinkIR: The University of Louisville's Institutional Repository. This title appears here courtesy of the author, who has retained all other copyrights. For more information, please contact thinkir@louisville.edu. 
COMMUNITY LEVEL IMPACTS OF MICROSTEGIUM VIMINEUM ON ARTHROPOD COMMUNITY STRUCTURE AND FOODWEB DYNAMICS IN A TEMPERATE DECIDUOUS FOREST

\author{
By \\ Judith L. Metcalf \\ B.S. University of Louisville, 2004 \\ M.A. Texas A\&M University - Corpus Christi, 2007

\begin{abstract}
A Dissertation
Submitted to the Faculty of the

College of Arts and Sciences of the University of Louisville

In Partial Fulfillment of the Requirements

for the Degree of
\end{abstract} \\ Doctor of Philosophy \\ Department of Biology \\ University of Louisville \\ Louisville, Kentucky
}

December 2013 

COMMUNITY LEVEL IMPACTS OF MICROSTEGIUM VIMINEUM ON ARTHROPOD COMMUNITY STRUCTURE AND FOODWEB DYNAMICS IN A TEMPERATE DECIDUOUS FOREST

\author{
By \\ Judith L. Metcalf \\ B.S. University of Louisville, 2006 \\ M.S. Texas A\&M University - Corpus Christi, 2007
}

A Dissertation Approved on

September 27, 2013

by the following Dissertation Committee:

\begin{tabular}{c}
\hline $\begin{array}{c}\text { Dissertation Director } \\
\text { Sarah Emery }\end{array}$ \\
\hline Margaret Carreiro \\
\hline Perri Eason \\
\hline Susanna Remold \\
\hline Lynne Rieske-Kinney
\end{tabular}




\section{DEDICATION}

This dissertation is dedicated to my parents,

Mr. Gerald Ray Metcalf

and

Mrs. Marie Metcalf

for instilling in me the belief that nothing is impossible and the knowledge that desire and hard work will always result in a positive outcome. Your love, support and unending faith in me made this work possible 


\section{ACKNOWLEDGEMENTS}

I would like to thank my advisor, Dr. Sarah Emery. When I joined your lab four years ago, I had no idea how much I would learn and how lucky I would be to have such a supportive advisor. I have enjoyed every minute of the last four years working with you, and I truly appreciate your patience in my times of frustration, your guidance when I struggled, and your excitement when my data actually showed something interesting. This process would have been so much more difficult without you. I would also like to thank each of my other committee members, Dr. Margaret Carreiro, Dr. Perri Eason, Dr. Susanna Remold and Dr. Lynne Rieske-Kinney, for their support, patience, comments and assistance over the past four years.

To all of the members of the Emery lab, thank you for the comments and edits on the manuscripts and posters and presentations. You have all provided a unique perspective on my project. The unending chaos when we all got together every week in lab meetings made this journey more entertaining. I especially want to thank the three undergraduate students who provided such amazing assistance both in the field and the lab over the course of this work: Amanda Parmann, Ayanna Jones and Cody Stevens. You all have amazing futures ahead of you.

To the Kentucky Academy of Sciences, without the support provided by the Marcia Athey Grant, this work would not have been possible. Additionally, I received financial support from the Horner Research Fund in the UofL Department of Biology and supplies and lab space from the Emery Lab. Thank you to the Department of Biology for 
granting me support through a teaching assistantship for the entirety of my work, and to the School of Interdisciplinary and Graduate studies for awarding me the Dissertation Completion Award that allowed me the necessary time to complete this work in my final semester.

To my friends both inside and outside of the university, as well as my Everyday Athletes gym family, too many to name individually, thank you all for your unending support, advice and friendship. I particularly want to thank my trainer and friend, Brad Longazel, you helped me more than you know, saved what was left of my sanity more times than I can count, provided me with a place to turn off work over the past 4 years and helped me see that I am stronger, both mentally and physically, than I ever imagined.

To both of my amazing sisters, you listened to me vent, offered support and provided me with so much helpful advice over the years. You are both my rocks and help keep me focused and grounded. Life would be so much less entertaining and interesting without you both. Thank you to my Dad, even though you have been gone from this world for more years than I had you with me, I know that you have been with me the whole way, and that the strength to push through when things got hard came from you. I love and miss you every day! Finally, I want to thank my mom for her time and patience, and her willingness to not only listen to me talk endlessly about my frustrations and excitements with my field work and data, but came out in the field on more than one occasion to help me collect and then spent hours helping me sort insects from leaf litter. I couldn't have asked for a more amazing, strong, loving and supportive mother! 


\title{
ABSTRACT \\ COMMUNITY LEVEL IMPACTS OF MICROSTEGIUM VIMINEUM ON ARTHROPOD COMMUNITY STRUCTURE AND FOODWEB DYNAMICS IN A TEMPERATE DECIDUOUS FOREST
}

\author{
Judith L. Metcalf
}

September 27, 2013

Invasion by non-native primary producers are generally expected to lead to a decline in native species richness, however in some cases, these invasions can actually lead to an increase in diversity and abundance of certain groups of organisms. Arthropods are extremely sensitive to changes in the plant community, particularly herbivores, and the response of these primary consumers can influence predator populations.

Microstegium vimineum is an invasive $\mathrm{C}_{4}$ grass that has developed strong populations in the understory of temperate deciduous forests along the east coast of the U.S. This work evaluates the influence that this invader may have on insect and spider abundance and diversity, including changes at the trophic group and functional guild levels. Additionally we evaluate the impacts of both an increase in invasion density and a decrease in native plant diversity on arthropod community structure.

In general, we find a significant increase in herbivore abundance, primarily as a result in the increased abundances of concealed chewers, free-living chewers and freeliving sap feeders. Free-living sap-feeders also showed an increase in biomass. Spider 
abundance and diversity also increased in association with invasion by M. vimineum. Both active hunters and sit-and-wait predators showed significant increases in invaded sites. The ratio of adult:immature spiders however had a negative relationship with invasion.

These changes in the arthropod community appear to be related to both changes in vegetation structure as well as changes in plant biomass. We found increased abundances in our treatments in which invasion density increased and decreases in the arthropod community in sites where native plants were removed from the system. We also show some support for the idea that carnivores, specifically spiders, may respond more strongly to changes in vegetative complexity, while herbivores, specifically leaf hoppers, may respond more strongly to changes in plant biomass. 
TABLE OF CONTENTS

PAGE

$\begin{array}{ll}\text { DEDICATION_ } & \text { iii } \\ \text { ACKNOWLEDGMETS_riv } & \text { vi } \\ \text { ABSTRACT } & \text { x } \\ \text { LIST OF TABLES } & \text { xi } \\ \text { LIST OF FIGURES } & \end{array}$

CHAPTER 1: INTRODUCTION___ 1

ORGANIZATION OF DISSERTATION__ 2

SITE DESCRIPTION __ 4

CHAPTER 2: CHANGES IN ARTHROPOD COMMUNITY STRUCTURE

ASSOCIATED WITH INVASION BY MICROSTEGIUM VIMINEUM 10

SUMMARY 10

INTRODUCTION_ 11

METHODS

RESULTS 16

DISCUSSION__ 18

CHAPTER 3: CHANGES IN SPIDER COMMUNITY STRUCTURE ASSOCIATED WITH INVASION BY MICROSTEGIUM VIMINEUM

SUMMARY 29

INTRODUCTION__ 30

METHODS 34

RESULTS 36

DISCUSSION__ 38 
CHAPTER 4: THE INVASIVE PLANT MICROSTEGIUM VIMINEUM ALTERS ARTHROPOD COMMUNITIES THROUGH CHANGES IN VEGETATION STRUCTURE AND DIVERSITY

SUMMARY 50

INTRODUCTION_

METHODS 55

RESULTS

DISCUSSION__ 61

CHAPTER 5: Summary and Future Directions __ 72

SUMMARY 72

FUTURE DIRECTIONS _ 72

REFERENCES _ 76

APPENDIX I _ 86

APPENDIX II__ 97

APPENDIX III__ 105

CURRICULUM VITAE___ 117 


\section{LIST OF TABLES}

PAGE

1. ANOVA Table: Plant Community percent cover and biomass___ 24

2. ANOVA Table: Insect abundance, biomass, richness and diversity___ 24

3. ANOVA Table: Insect trophic group abundance and biomass___ 24

4. ANOVA Table: Herbivore functional guild abundance and biomass___ 25

5. ANOVA Table: Spider total abundance, Family richness, diversity and evenness, and Genus richness, diversity and evenness 44

6. ANOVA Table: Ratios of adult to immature spiders 44

7. ANOVA Tables: Functional guild total abundance and relative abundance 45

8. Description of and mechanisms tested for each treatment 68

9. ANOVA Tables: Plant community percent cover, plant architecture and bare ground $\%$ cover

10. ANOVA Tables: Total arthropod abundance by trap type, sweep net diversity, richness and evenness, and trophic group abundance

11. ANOVA Tables: carnivore functional group abundance, predator morpho-group abundance, herbivore functional group abundance and free-living sap-feeder morpho-group abundance 


\section{LIST OF FIGURES}

PAGE

1. Mechanisms driving impacts of invasive plants on arthropod communities 7

2. Schematic of transect layout and photos of invaded and uninvaded plots 8

3. Schematic of plot arrangement of the randomly assigned treatments 9

4. Schematic of sampling area and pitfall layouts and photos typical treatments_10

5. Plant community $\%$ cover, Bare ground $\%$ cover and mean plant biomass _ 26

6. Insect abundance, biomass, diversity and family richness 27

7. Insect community NMS results 28

8. Insect trophic group abundance and biomass, and herbivore functional guild abundance and biomass

9. Spider abundance, Family richness, Genus richness and Genus diversity by trap type 46

10. Spider community NMS results 47

11. Ratio of adult: immature spiders by trap type 48

12. Spider Functional guild total abundance by trap type 49

13. Spider Functional guild relative abundance by trap type 50

14. Percent cover of plant community, mean plant architecture and percent cover of bare ground by treatment: Control, $M v(-) ; M v$ mono; $M v(+)$ 70

15. Arthropod abundance, diversity, richness and trophic group abundance by treatment: Control, $M v(-) ; M v$ mono; $M v(+)$ 71 
16. Predator abundance, predator morpho-group abundance, Free Living sap feeder abundance, and free-living sap feeder morpho-group abundance by treatment:

Control, $M v(-) ; M v$ mono; $M v(+)$ 


\section{CHAPTER 1: INTRODUCTION}

The introductions of exotic species alter regional biota and cause native species to decline, making them a major threat to global ecosystems (Elton 1958, Winemiller and Polis 1996, Adams and Engelhardt 2009). However, exotic species’ presence can sometimes lead to increases in diversity and abundance of some groups of organisms. Plants serve as the foundation of terrestrial food webs and non-native invasive plants may have mixed effects on diversity. One group of organisms that is expected to be highly sensitive to invasive plant presence is arthropods, especially herbivores that form close associations with the plant community (Carvalheiro et al. 2010). Changes to the herbivore community can in turn impact predator abundance and fitness (Oliver 1998). Further, invasive plants can influence arthropod predators by altering habitat availability (Standish 2004). It becomes important to quantify multi-trophic level effects of plant invasions in order to best understand how the overall ecosystem will respond to these non-native primary producers.

The first step in understanding invasive plants' effects on other trophic levels is to quantify their impacts within trophic levels. Non-native plant invaders can alter the native plant community via three primary pathways: decreases in native plant diversity and biomass, increases in overall productivity, and alterations in structural complexity (Mack et al. 2000, Meiners 2001, Denno et al. 2002, Civitello et al. 2008, Maron and Marler 2008, Wimp et al. 2010, Ehrenfeld 2011) (Fig. 1). These three pathways can each lead to changes in higher trophic levels, potentially altering arthropod abundance and diversity in the invaded system. 
Native plant diversity can be significantly reduced by exotic plants that outcompete native species (Mack et al. 2000, Meiners 2001). Reductions in plant species diversity can mean a loss of habitat and food resources for arthropods (Civitello et al. 2008, Cheplick 2010). In many cases, invading plant species are not as nutritionally beneficial to herbivores in a system, and this reduced nutritional quality may limit herbivore biomass, leading to reduced prey quality for predators (Winemiller and Polis 1996, Heleno et al. 2008). Heleno et al. (2008) showed a significant decrease in insect biomass and diversity as native plants were replaced by non-native primary producers on Sao Miguel Island in the Azores archipelago. The lack of accompanying change in insect abundance indicates that the larger insects are being replaced by similar numbers of smaller insects. This depletion of high-quality prey could have significant consequences for higher trophic levels (Heleno et al. 2008).

While native plant diversity frequently declines as a result of non-native plant invasion, total plant productivity and standing crop biomass often increase by as much as 56\% (Levine et al. 2003, Ehrenfeld 2003). Increases in plant productivity can lead to increases in herbivore density and species richness (Wimp et al. 2010). Increases in herbivore density can lead to increases in abundance of predators, which can then feed back onto the herbivore population as a function of increased prey consumption or changes in herbivore foraging behavior, potentially decreasing the effectiveness of herbivores in controlling primary producers (Carpenter et al. 1985, Strong 1992, Schmitz et al. 2000, 2004, Werner and Peacor 2003, Grabowski et al. 2008).

Although plants are generally thought of as energy providers for higher trophic levels, they are also capable of affecting these groups of organisms in other direct ways (Pearson 2009). Primary producers, both native and invasive, create three-dimensional 
landscapes in which higher trophic levels interact (Pearson 2009). Structure and architecture of plant communities have been shown to be determining factors in both the abundance and diversity of both herbivorous and predatory arthropods (Lawton and Strong 1981, Lawton 1983). Spiders in particular show predictable responses to variation in habitat structure (Gibson et al. 1992), with habitat complexity impacting prey capture rates, as well as altering intra-guild interactions. Changes in habitat structure can also expand niche diversity for parasitoids, leading to increased abundances of these organisms (Kneitel and Miller 2002, Langellotto and Denno 2004).

The ability to differentiate among effects of invasive plants on plant community, structure and biomass are vital to the effective management and control of invasive plants. A clear understanding of how these different components of plants invasion can impact both the plant community and higher trophic levels, will allow land managers to better prioritize management objectives in terms of control or removal regimes for invasive plants.

\section{ORGANIZATION OF DISSERTATION}

In this dissertation, I use a community-level approach to understand the impacts of invasion on arthropod communities. I use observational field studies and a manipulative field experiment to identify patterns of arthropod diversity associated with one particular invasive plant common to the Eastern US, and to identify potential mechanisms by which this invasive plant alters arthropod communities.

In the second and third chapters of this dissertation, I examine associations between the aggressive invader, Microstegium vimineum and insect and spider community structure, including abundance, diversity, biomass and trophic level interactions in a disturbed temperate forest in Brownsboro, KY. I use the natural patchy 
distribution of $M$. vimineum in this system to compare arthropod communities in habitats both invaded and uninvaded by $M$. vimineum. In the second chapter, I show that invasion by $M$. vimineum is associated with increases in arthropod abundance, richness and diversity, mostly due to increases in herbivores, particularly concealed chewers, freeliving chewers, and sap feeders. Microstegium vimineum was also associated with decreases in forb abundance and increases in standing crop biomass. These results indicate that the arthropod community may be responding to an increase in plant cover and structural complexity, rather than a change in food availability.

In the third chapter I examine the association between spiders, the dominant invertebrate predator in the system, and $M$. vimineum. Spiders can respond not only to the available prey in a system, but also to changes in the structural complexity in the environment. Using the same observational study design as in chapter two, I compared spider abundance, diversity, functional guilds, and demographic structure (adult: immature ratios) in invaded and uninvaded sites. I show that invasion by $M$. vimineum is associated with increases in spider abundance and diversity, mostly due to significant increases in the active hunter and sit-and-wait functional guilds. Additionally, the ratio of adult:immature spiders was negatively associated with invasion by $M$. vimineum. While I cannot determine the mechanism for these associations without further study, these results indicate that $M$. vimineum invasion could lead to increased abundances of spiders.

In chapter four, I manipulated the plant community to address potential mechanisms by which $M$. vimineum presence could alter arthropod communities. I was particularly interested in the different effects that a reduction in native plant diversity vs. increases in plant community biomass and structure could have on arthropods. I utilized 
four treatments (a control; a Microstegium removal [Mv(-)]; a Microstegium monoculture [Mv mono]; and a Microstegium addition $[M v(+)])$ to show that $M$. vimineum can alter arthropod abundance and diversity through both increases in structural complexity and biomass availability and reductions in native plant diversity. Carnivores, specifically spiders, appear to be responding more strongly to changes in structural complexity, while herbivores, particularly leaf hoppers, may respond more strongly to changes in biomass availability.

In chapter five, I give a general summary of the findings of my dissertation research and present possible future research directions, including expanding the manipulative study to improve our understanding of the differential effects of plant biomass and structure, as well as the possible influences of patch size on arthropod community structure.

\section{SITE DESCRIPTION}

All research described in this dissertation took place in the University of Louisville Horner Wildlife Refuge (Brownsboro, KY: 38:20:27N, 85:31:53.7W). This 81-ha, highly disturbed, second-growth temperate forest has an upland area devoid of any natural permanent water source, and a lowland area that borders a stream. An invasion of M. vimineum of unknown age is patchily distributed throughout the forest. The forest, which lies between interstate I-71 and a limestone quarry in Brownsboro KY, was donated to the University in the 1960's by Mr. and Mrs. William Horner, Sr. for use as a wildlife sanctuary and bird refuge. The property is bounded on the south by the south fork of Harrods Creek and on the north by the "Standing Stone Branch" or north branch of Harrods Creek. The property was residential at one point in its past, containing an Inn, 
the Babbitt Mill, a farm house and a barn, among other structures that are no longer standing (personal communication, John Kielkopf September 6, 2013).

Surveys described in chapters two and three were designed utilizing the naturally patchy distribution of $M$. vimineum in this system. Twenty-four transects, each $25 \mathrm{~m}$ long were established in both the upland (12 sites) and lowland (12 sites) habitats (Fig. 1). Within each habitat, six transects were located in 'invaded' sites (>10\% $M$. vimineum) and six were located in 'uninvaded' sites ( $<10 \%$ M. vimineum) (Fig. 2)

The experiment described in chapter four was established in a large, invaded area of understory in the upland habitat. Treatments (control; a Microstegium removal [Mv(-)]; a Microstegium monoculture [Mv mono]; and a Microstegium addition $[M v(+)])$ were randomly assigned to the $402 \mathrm{~m} \times 2 \mathrm{~m}$ plots, laid out in a $4 \times 10$ grid (Fig. 3). The interior $1 \mathrm{~m}^{2}$ of each plot was identified by flags indicating treatment by color and delineating the sampling area for each plot (Fig. 4). 


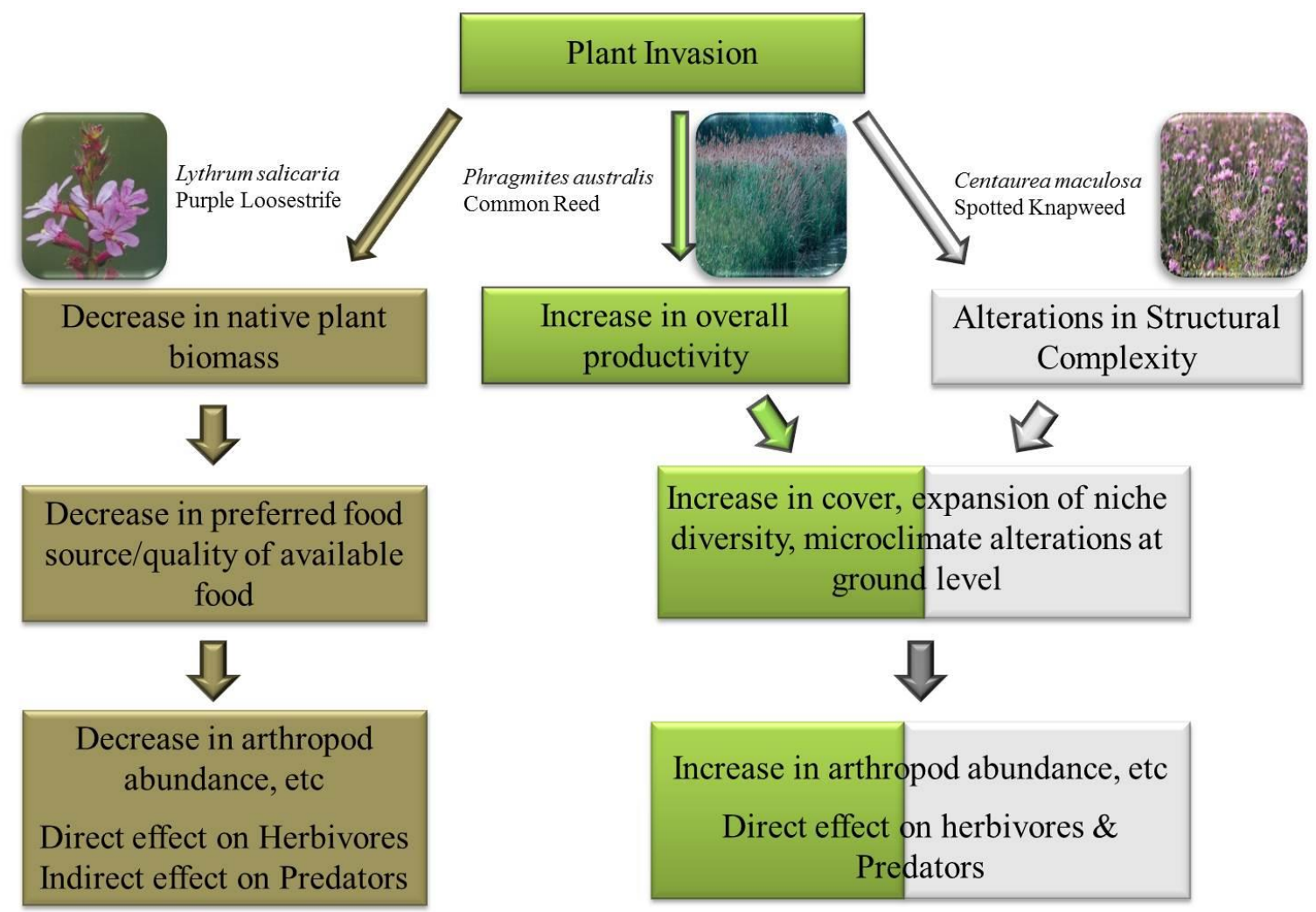

Figure 1. Mechanistic effects of plant invasion on native plant and arthropod communities 


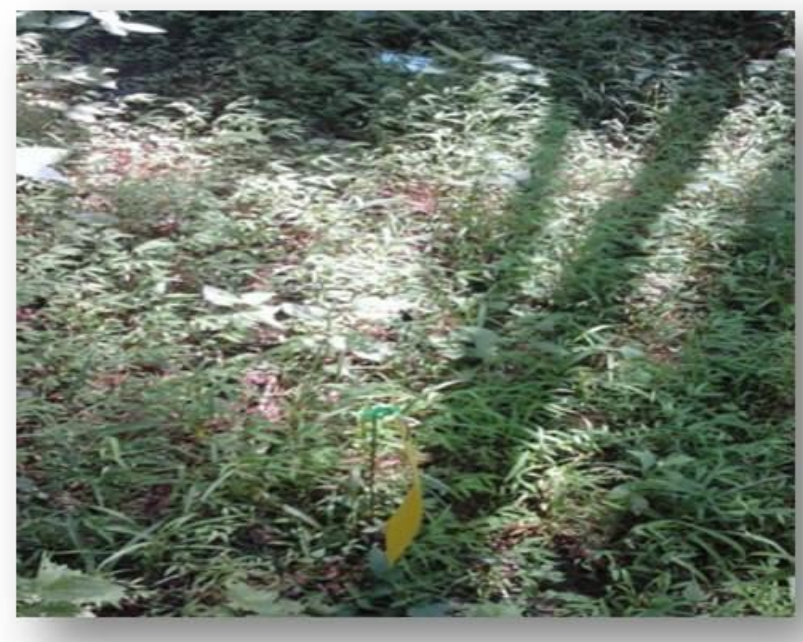

12 Uninvaded

$(0-<10 \%$ M. vimineum $)$

Mean $=4 \%$

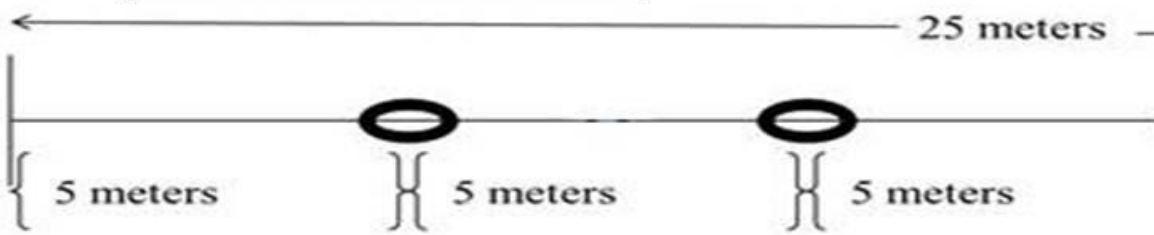

$\longrightarrow=$ pitfall trap

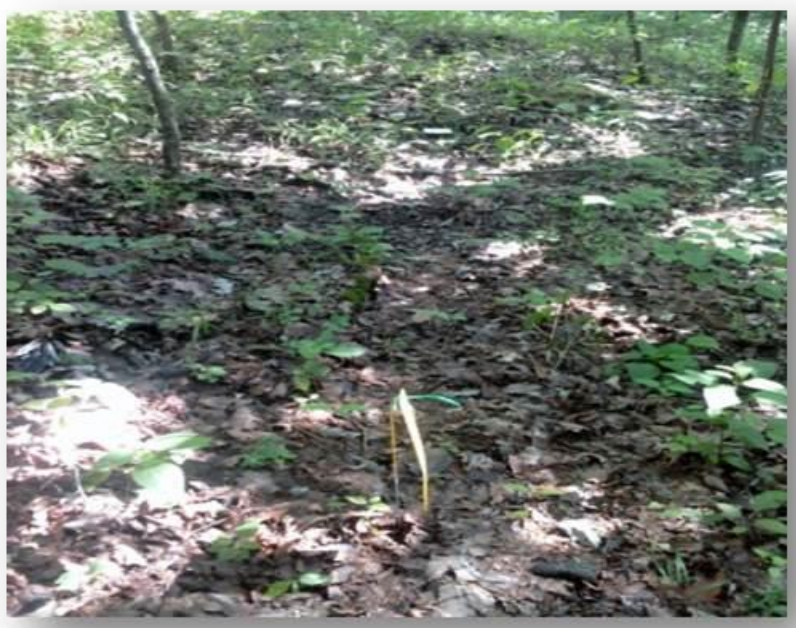

12 Invaded

$(0-<10 \%$ M. vimineum $)$

Mean $=48 \%$

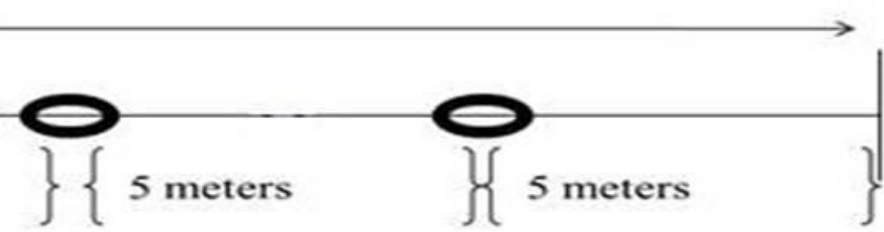

Figure 2. Photographs of typical 'uninvaded' and 'invaded' sites and diagram of the layout for each of the 24 transects used in this study 


\begin{tabular}{|c|c|c|c|}
\hline$M v(+)$ & $\mathbf{M v}(-)$ & Control & Mv mono \\
\hline Control & Mv mono & $M v(+)$ & Control \\
\hline $\mathbf{M} v(-)$ & Mv mono & $M v(+)$ & $\mathbf{M v}(-)$ \\
\hline$M v(+)$ & $\mathbf{M v}(-)$ & $M v(+)$ & $\mathbf{M} v(-)$ \\
\hline $\mathbf{M v}(-)$ & Control & Mv mono & $M v(+)$ \\
\hline Mv mono & $M v(+)$ & Control & $\mathbf{M} v(-)$ \\
\hline$M v(+)$ & Control & Mv mono & Control \\
\hline$M v(+)$ & Control & Control & Mv mono \\
\hline $\mathbf{M v}(-)$ & Mv mono & $\mathbf{M v}(-)$ & Control \\
\hline $\mathbf{M v}(-)$ & $M v(+)$ & Mv mono & Mv mono \\
\hline
\end{tabular}

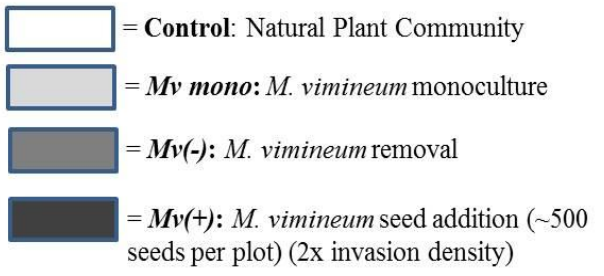

Figure 3: Plot arrangement of the randomly assigned treatments within the $4 \times 10$ grid of establised $2 \mathrm{~m} \times 2 \mathrm{~m}$ plots 

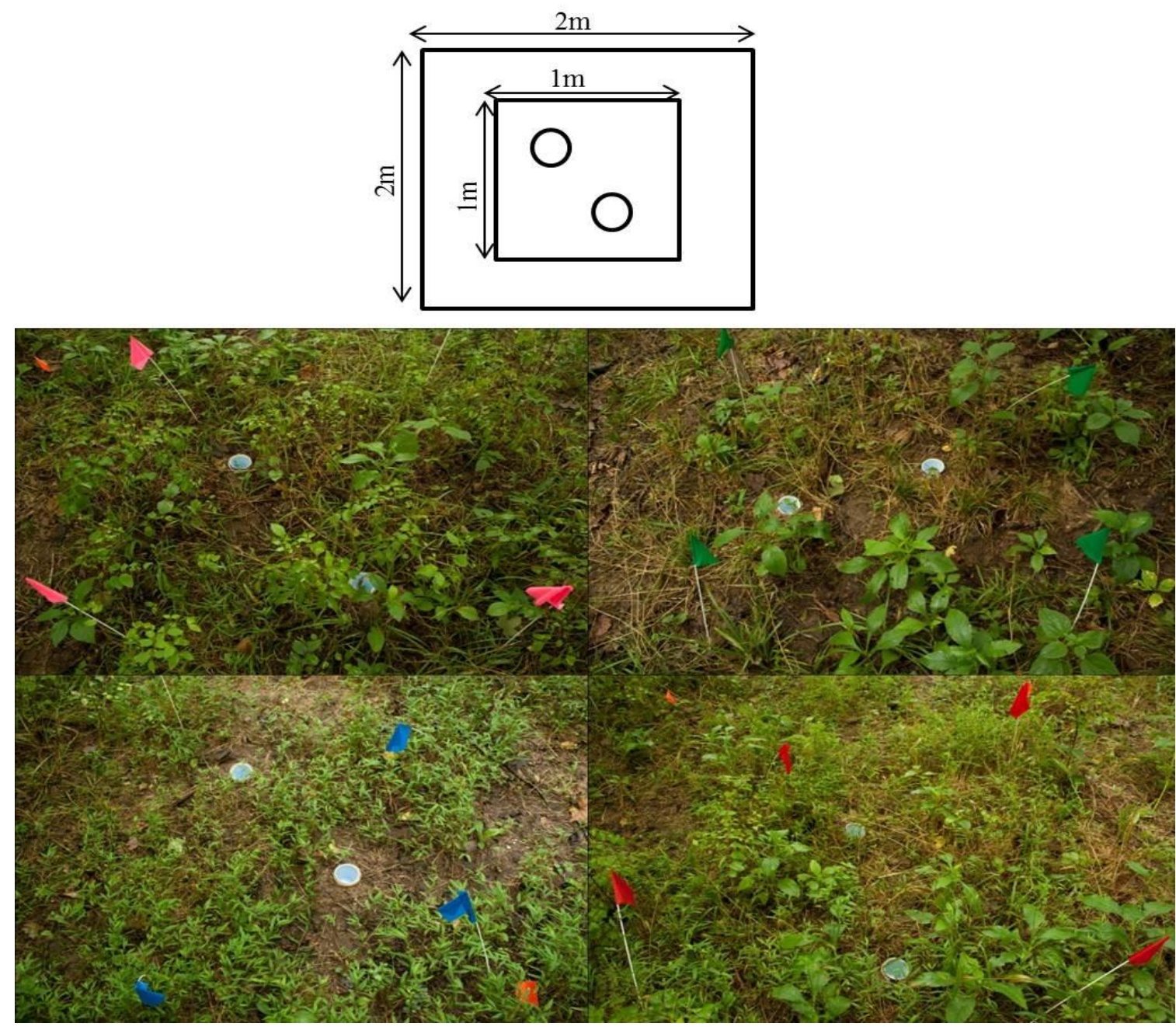

Figure 4: A) diagram showing layout of individual plots with interior squares indicating sampling area and circles indicating pitfall traps. B) Photographs of plots showing typical plant communities after application of each treatment. 


\section{CHAPTER 2}

\section{CHANGES IN INSECT COMMUNITY STRUCTURE ASSOCIATED WITH}

\section{INVASION BY MICROSTEGIUM VIMINEUM}

\section{SUMMARY}

Microstegium vimineum is an annual $\mathrm{C}_{4}$ grass that is invasive in many eastern deciduous forests. Because this grass plays an important role in determining the plant community structure in the understory of these forests, it also has the potential to significantly alter insect community structure (Flory and Clay, 2010a; 2010b). In this study we evaluated the relationship between Microstegium vimineum and insect communities in a disturbed forest in Kentucky. Total insect abundance, richness and diversity showed a positive association with $M$. vimineum presence. Trophic analysis showed significantly higher abundances of herbivores, including concealed chewer, free-living chewer and free-living sap-feeder functional guilds where $M$. vimineum was present. Herbivore biomass increased in the presence of $M$. vimineum; however this increase was limited to the freeliving sap feeder functional guild. Forb abundance, which serves as the primary food source for herbivorous arthropods in this system, was lower in sites invaded with $M$. vimineum. Invasion by this non-native was also associated with significant increases aboveground plant biomass which was nearly $50 \%$ greater in invaded sites. These results indicate that the arthropod community may be responding to increased biomass rather than the loss of native forbs resulting in a loss of food resources. 


\section{INTRODUCTION}

Invasive plant species are considered a major threat to biodiversity and ecosystems worldwide (Heleno et al., 2008). These invasive non-native plants have the potential to alter regional biota, specifically impacting plant community composition and native plant species abundance (Hobbs and Humphries, 1995; Adams and Engelhardt, 2009). These effects can consequently alter diversity of other trophic groups, including herbivorous insects that often depend on native vegetation for habitat and food. Invasive plants can alter the structure and function of plant communities to such a degree that they have significant impacts on the arthropod communities (Simberloff, 1996; Mack and D'Antonio, 2003; Adams and Engelhardt, 2009; Tang et al., 2012). The typical reduction in native plant biomass that accompanies invasion often results in a reduction in the abundance and biomass of primary consumers, and consequently their predators, as invasive plants outcompete native plants (Tallamy, 2004; Carpenter and Cappuccino, 2005). For example, Heleno et al. (2008) found a negative relationship between percent invasive plants and total species richness of both plants and insects on Sao Miguel island, part of the Azores archipelago. A number of other studies have also demonstrated a decrease in insect total abundance, species richness and diversity, and trophic and guild structure, particularly for herbivorous insects, in relationship to invasion by non-native plants (Mgobozi et al., 2008; Wu et al., 2009; Yoshioka et al., 2010; Simao et al., 2010).

However, there is often an associated increase in overall productivity that accompanies plant invasion that can have positive effects on certain arthropods as a result of increased cover, expansion of niche diversity, and micro-climate alterations at ground level (Strauss, 1987; Siemann, 1998; Gratton and Denno, 2003; Cebrian et al., 2009). For example, Pearson (2010) found significant increases in predator densities of Dictyna 
spiders in areas where spotted knapweed, Centaurea maculosa, had invaded as a result of altered vegetative complexity that increased availability of necessary web-building substrates that are limited in the absence of this invader. Others have found increases in arthropod communities at multiple trophic levels (Samways and Moore, 1991; Lambrinos, 2000; Mayer et al., 2005; Topp et al., 2008) in a variety of invaded habitats. Wimp, et al. (2010) demonstrated that increases in plant productivity associated with invasion, decoupled from changes in plant community composition, were associated with increased arthropod species richness at all trophic levels, as well as increased overall diversity of rare species in salt marshes invaded by monoculture stands of Spartina alterniflora. It is likely that the various arthropod groups being studied, as well as the level of invasion and the identity of invading plants being studied contribute to these differences (Simao et al., 2010).

In this study, we evaluated the associations between insect communities and the invasive grass Microstegium vimineum (Trin.) A. Camus. This annual $\mathrm{C}_{4}$ grass (Poaceae), also known as Japanese Stiltgrass, was accidentally introduced to the US in the early 1900s as packing material (Fairbrothers and Gray, 1972; Barden, 1987), and is a prevalent invader throughout the eastern U.S. It is considered a species of concern due to its ability to thrive in the understories of deciduous forests, often outcompeting native forbs and grasses (Oswalt et al., 2007; Civitello et al., 2008; USDA, 2008; Flory and Clay, 2009; Adams and Engelhardt, 2009; Flory, 2010). Microstegium vimineum is an early spring germinating annual that reaches peak biomass in late summer, produces a high volume of seed in early fall and leaves behind a dense mat of litter (Barden, 1987; Hunt and Zaremba, 1992, Redman, 1995). Microstegium vimineum has been shown to significantly impact plant community composition, reducing native plant diversity and 
biomass which could have serious effects on arthropod community structure (Barden, 1987; Civitello et al., 2008; Flory and Clay, 2009; Adams and Engelhardt, 2009; Simao et al., 2010).

The goal of this study was to evaluate the response of the insect community to invasion by $M$. vimineum in a deciduous forest in Kentucky. In particular, we ask: (1) Is invasion by $M$. vimineum associated with changes in plant community structure and available biomass? (2) Do sites invaded by $M$. vimineum differ from uninvaded sites in terms of arthropod abundance, biomass and diversity? (3) Do arthropod trophic level and functional group abundance and diversity (predator, parasite, parasitoid, concealed chewer, free-living chewer, free-living sap feeder, pollinator, scavenger/shredder) differ between sites invaded by $M$. vimineum and uninvaded sites?

\section{METHODS}

\section{Sampling Design}

This study was conducted at the University of Louisville Horner Wildlife Research Forest in Brownsboro, Kentucky $\left(38: 20: 27^{\circ} \mathrm{N}, 85: 31: 53.7^{\circ} \mathrm{W}\right)$. This is an 81 ha, highly disturbed, second-growth, temperate, deciduous forest in Northern Kentucky, with an upland area devoid of any natural permanent water source, and a lowland area bordering the south-fork of Harrods Creek. In May 2010, we established $2425 \mathrm{~m}$ transects, 12 in upland habitats and 12 in lowland habitats. Using a visual estimate of percent cover within each habitat, six transects were located in 'invaded' sites (averaging 48\% M. vimineum) and 6 were located in 'uninvaded' sites (averaging $\sim 4 \% \mathrm{M}$. vimineum).

Arthropod sampling. 
Arthropod samples were collected once per month during two growing seasons (May-October 2010, 2011) using pitfall traps and sweep nets. Pitfall trap transects were $20 \mathrm{~m}$ in length, with one pitfall trap placed every $5 \mathrm{~m}$ along the length of each transect, for a total of 4 pitfall traps per transect. Traps were made using $10.16 \mathrm{~cm}$ diameter PVC pipe cut to $10.16 \mathrm{~cm}$ long and placed flush into pre-dug holes in the soil. Traps were set by placing empty $0.24 \mathrm{~L}$ plastic cups into the PVC. After 48 hours, the cups were removed from the PVC and samples were pooled and emptied into zip-top bags for transport back to the lab. Two $1 \mathrm{~m}$ wide sweep net samples (15 sweeps per transect) were collected along each transect. Sweep net samples were pooled for each transect, transferred to ziptop bags and returned to the lab. Samples were stored at $-10^{\circ} \mathrm{C}$ until processing.

Individual arthropods were identified to the family level using Johnson and Triplehorn (2005), and were assigned to a trophic group (carnivore, herbivore, omnivore and detritivore) and guild (parasite, parasitoid, predator, concealed chewer, free-living chewer, free-living sap feeder, pollinator, scavenger/shredder) using feeding information found in Marshall (2009) and Gratton \& Denno (2005).Samples were then sorted by sampling method, family, site and date, and placed in a drying oven $\left(40^{\circ} \mathrm{C}\right)$ for $48 \mathrm{~h}$ and weighed.

\section{Vegetation and environmental sampling.}

Above-ground standing-crop biomass and litter biomass were collected using two $0.25 \mathrm{~m} \times 0.25 \mathrm{~m}$ quadrats, randomly placed along each transect, while ensuring that no location was sampled twice, each month. Live biomass was clipped at ground level; litter included tree leaf litter and other non-living plant material rooted or lying on the ground, but excluded woody debris. Live $M$. vimineum and litter material were separated from all other plant material, oven dried at $40 \mathrm{C}$ for 48 hours, and weighed. 
Two 'permanent' community plots $\left(1 \mathrm{~m}^{2}\right)$ were established along each transect (one at each end, on alternating sides) to visually estimate percent cover of M. vimineum, forbs, non-M. vimineum grasses, sedges, tree seedlings and bare ground for each transect. In 2011, additional data were collected in these community plots, canopy cover (using a Spherical Crown Densiometer), and plant height (measured using a standard meter stick). Canopy cover data were collected by averaging the open space for each of the four sides of the community plot. Plant height was reported as the average plant height from five measurements (one at each corner, and one in the center of each community plot)

\section{Data Analysis}

We conducted a mixed general linear model with habitat (upland vs lowland) as a random factor, invasion status as a fixed factor and year and season as covariates on data from the 24 transects to compare the associations of invasion and plant community structure and biomass, environmental variables, and arthropod abundance, biomass and diversity. Shannon diversity indices (Shannon, 1948) were calculated using both arthropod family abundance values and arthropod biomass. Initial analyses were completed at the family and trophic levels, then significantly different trophic levels were analysed at the functional guild level. All analyses were completed using Systat v. 13 (2009).

Multi-response permutation procedures (MRPP) with a Euclidean distance measure (Zimmerman et al., 1985) were used to compare arthropod community composition between invaded and uninvaded sites. MRPP is similar to multivariate analysis of variance (MANOVA) but does not rely on the assumptions of normality, which is rare in community data such as these. To better visualize the differences in family diversity between invaded and uninvaded sites, we used Nonmetric Multidimensional Scaling 
(NMS) (McCune and Grace, 2002) with Bray-Curtis dissimilarity measures. This ordination technique is similar to Principal Components Analysis, but uses ranked distance between plots to estimate similarity to avoid assumptions about linearity or unimodality of the community data. This analysis is well suited for ecological community data as they tend to be non-normal and discontinuous (McCune and Grace, 2002). For this analysis, we used a random starting configuration with 250 runs with real data and 250 runs with simulated data. PC-ORD v 5.10 (McCune and Mefford, 1999) was used for the MRPP and NMS analysis.

\section{Results}

\section{Vegetation and environmental variables.}

The plant community differed significantly between invaded and uninvaded sites (Table 1A, Fig. 5A). Microstegium vimineum percent cover was significantly higher in invaded sites $(38.7 \% \pm 2.17)$ than in uninvaded sites $(5.81 \% \pm 1.19)$. Forbs made up a significantly larger percentage of the overall plant community in uninvaded $(33 \% \pm 1.68)$ sites as compared to invaded $(24 \% \pm 1.29)$ sites, but there were no differences in grasses, sedges or tree seedlings. Additionally, there was significantly more bare ground present in uninvaded $(53 \% \pm 2.31)$ as compared to invaded ( $28 \% \pm 2.12)$ sites (Table 1B, Fig. 5B).

Biomass of primary producers also differed between invaded and uninvaded sites (Table 1B, Fig. 5C).

Analyses of plant height and canopy cover showed significant, although opposing differences between treatments with $23 \%$ taller plants $(\mathrm{F}=14.92, \mathrm{p}<0.001)$ in invaded sites and $2.1 \%$ more canopy cover $(\mathrm{F}=35.07, \mathrm{p}<0.001)$ in uninvaded sites.

Arthropod abundance and biomass.--Over the course of the 2010-2011 field seasons, 26861 total arthropods comprising 138 families were collected using pitfall traps (3657 
total arthropods; 40 families) and sweep nets (23204 total arthropods; 98 families).

Sweep net samples showed significant increases in abundance (Table 2, Fig. 6A) in areas invaded by $M$. vimineum, with invaded sites containing approximately $57 \%$ more individuals than uninvaded sites. Biomass was $9.5 \%$ higher in invaded sites; however after adjustment for multiple comparisons this difference was no longer statistically significant (Table 2, Fig. 6B). Because there were no significant differences between invaded and uninvaded sites for pitfall traps in either abundance $(\bar{X}=6.4 \pm 0.9 ; \mathrm{F}<0.001$, $\mathrm{p}=0.990)$ or biomass $(\bar{X}=0.09 \mathrm{~g} \pm 0.02 ; \mathrm{F}=0.105, \mathrm{p}=0.746)$, these data were eliminated from further analyses.

\section{Arthropod diversity}

Diversity (Fig. 6C) and family richness (Fig. 6D) differed between treatments, with invaded sites containing $27 \%$ more families, and having $16 \%$ higher Shannon diversity index at the family level. Shannon evenness $\left(E_{h}\right)$, calculated by dividing Shannon diversity by the natural log of species richness, did not differ between treatments (Table 2).

Invaded sites differed from uninvaded sites in community composition (MRPP: $\mathrm{p}=<0.01 ; \mathrm{A}=0.02)$. The NMS analysis indicated that sites were most clearly separated by Axis 2 components (Fig. 7, $\mathrm{R}^{2}=0.67$ ). Bi-plot analysis shows that aboveground biomass had important influence along this axis. Invasion by $M$. vimineum was generally positively associated with Acrididae, Tetrigidae and Tettigonidae (grasshoppers), Cercopidae (Tree hoppers), Curculionidae (Weevils), Lepidopteran larvae (Larva), Pentatomidae (Stinkbugs), and Rhyparochromidae (Seed bugs).

Arthropod trophic groups and guild structure. 
Herbivore abundance differed significantly between treatments with uninvaded sites having 55\% fewer individuals than invaded sites (Table 3A, Fig 8A). Trophic level increases in arthropod biomass were found between invaded and uninvaded sites for both herbivores (95\%) and carnivores (67\%) (Table 3B, Fig 8B).

Because herbivores were the only trophic group to differ statistically across sites after Bonferroni correction, we followed with an analysis of functional guilds within this trophic group only. We found significant increases in the abundance of concealed chewers (58\%), free-living chewers (61\%) and free-living sap-feeders (53\%) in invaded sites (Table 4A, Fig 8C). Pollinators did not differ between treatments. Differences in biomass at the functional guild level were limited to the free-living sap feeders which demonstrated a $75 \%$ increase in biomass in invaded sites (Table 4B, Fig 8D).

\section{DISCUSSION}

The effects of Microstegium vimineum on native plant communities are well documented, with consistent decreases in native plant community diversity and general overall increases in aboveground biomass (Barden, 1987; Oswalt et al., 2007; Flory, 2010). This study supports those effects, showing definitive changes in plant community structure as well as increases in both aboveground biomass and leaf litter associated with the presence of $M$. vimineum. The most notable difference in the plant community was the decrease in native forbs in invaded sites.

The results of this study show a clear increase in the abundance and family richness and diversity of insect communities, as well as shifts in trophic and functional guild structure in sites invaded by $M$. vimineum. Increases in abundance were restricted to herbivores; and within this trophic group increases were consistent across all functional 
guilds, excluding pollinators. The free-living sap feeder guild showed increases in biomass as well as abundance.

There are several mechanisms by which $M$. vimineum could increase herbivore abundance in this system. While $M$. vimineum is predicted to have lower nutritional quality compared to $\mathrm{C}_{3}$ plants such as the forbs found in this area due to lower levels of protein, carbohydrate, and water, along with increased levels of silica and fiber typically present in $\mathrm{C}_{4}$ plants (Caswell et al., 1973; Barbehenn, 2005; Cebrian et al., 2009), there is evidence that $\mathrm{C}_{4}$ plants in general, and $M$. vimineum specifically, can serve as a food source for certain arthropod groups (Barbehenn, 2005; Bradford et al., 2009; Tang et al., 2012). Bradford (2009) found that certain guilds, i.e. chewers and sap-feeders, may use the invader as an exclusive food source. We did find increased herbivore abundance, primarily free-living sap feeders, which may indicate the use of $M$. vimineum as a food source in invaded sites in this system. Alternatively, the increase in vegetation density associated with $M$. vimineum invasion could be driving the herbivore increase. Increasing plant biomass increases habitat availability and cover, and is a good predictor of arthropod abundance (Borges and Brown, 2001). Samways (1996) showed that increasing vegetation height increased arthropod species richness in South African grasslands. We did indeed find increased plant height with $M$. vimineum invasion (mean height of $50 \mathrm{~cm}$ as compared to mean height of $40 \mathrm{~cm}$ in uninvaded sites). The combination of increased cover provided by $M$. vimineum combined with the remaining $\mathrm{C}_{3}$ food resources may result in an increase in habitat complexity that is able to support higher arthropod richness in this system.

While we did see some differences in arthropod abundance and biomass associated with habitat, year, and season, there were no consistent patterns in these 
differences, and the differences in invaded and uninvaded sites were highly significant even with these factors incorporated into the model. Yearly variation is likely attributed to differences in climate with increased annual rainfall which was 76\% higher in 2011 (mean precipitation of $172.78 \mathrm{~cm}$ as compared to 2010 (mean precipitation=97.82 $\mathrm{cm}$ (NOAA, 2011) and corresponding to higher arthropod abundance in the second year of the study. These types of variation in arthropod communities are common (Denlinger, 1980; Lowman, 1982) and do not directly address the questions in this study.

This study adds to a relatively limited body of literature evaluating the impacts of M. vimineum on arthropod communities. Other studies have previously demonstrated that invasion by M. vimineum invasion is associated with increases in (Tang et al., 2012), decreases in (Civitello et al., 2008; Simao et al., 2010), or no effect on arthropod abundance and diversity (Marshall and Buckley, 2009). Simao (2010) used a common garden approach, creating artificial communities and invasions, and found decreases in the arthropod community (abundance and richness) associated with invasion. Tang (2012) and Marshall and Buckley (2009) established their transects in previously existing M. vimineum invasions and found increases in or no effect on arthropod community associated with invasion. These contradictions lead us to conclude that the effects of this invasive plant on arthropod communities may be context dependent, and more work is necessary to evaluate the specific factors that may be driving these changes in different systems. For example, the density of the $M$. vimineum invasion may be responsible for driving some of the changes in these systems. Future work on impacts of $M$. vimineum density on insect communities would be useful in evaluating this hypothesis.

If differences in invasion density affect arthropod abundance, we would expect to see a significant effect of $M$. vimineum biomass on arthropods in our study. Indeed, we 
found some positive, though non-significant, correlation between aboveground biomass and insect abundance $(\mathrm{r}=0.122, \mathrm{p}=0.24)$ and insect biomass $(\mathrm{r}=0.143, \mathrm{p}=0.17)$ in sites invaded by M. vimineum. This correlation, although small, along with the association between $M$. vimineum and plant community structure indicate that invasion density may be affecting changes in these arthropod communities. The age of the invasion in this area is unknown; however the limited number of invaded patches, as well as the presence, although reduced, of native forbs remaining in invaded sites lead us to believe that it is a relatively new invasion. Over time, increasing invasion density could lead to $M$. vimineum outcompeting native forbs for resources, ultimately resulting in reduced arthropod abundance and diversity.

Because arthropods play an important role in many ecosystems, serving as decomposers, herbivores, carnivores (consumers) and pollinators, changes in arthropod communities could have important implications, beyond their biodiversity value, for ecosystem function and diversity at other trophic levels. Herbivores play an important role in the transfer of energy from primary producers to higher trophic levels (Price et al., 2011). Therefore increasing herbivore densities associated with increased invasive plant presence could also indirectly affect the fitness of native plants through apparent competition (Lau and Strauss, 2005). More detailed studies of the mechanisms driving changes in higher trophic levels due to plant invasion are needed. 


\section{ACKNOWLEDGEMENTS:}

Thanks to Allison Smith, Amanda Parmann, Ayanna Jones, Brad Gottschall, Catherine

Fargan, Cody Stevens, Jeff Masters, and Marie Metcalf for field and lab assistance. This research was made possible through the Kentucky Academy of Sciences Marcia Athey

Grant, the University of Louisville Horner Research Fund and the University of Louisville Department of Biology. 
Table 1: Results from mixed general linear models for plant community percent cover (A) and Aboveground and Litter Biomass (B). Bonferroni adjusted significant p-values are shown in bold.

\begin{tabular}{|c|c|c|c|c|c|c|c|c|}
\hline \multirow{2}{*}{ (A) } & \multirow{2}{*}{ DF } & Forb & Grass & \multicolumn{2}{|c|}{ M. vimineum } & \multicolumn{2}{|r|}{ Sedge } & Tree Seedling \\
\hline & & $\mathrm{F}, \mathrm{p}$ & F,p & \multicolumn{2}{|c|}{ F,p } & \multicolumn{2}{|r|}{ F,p } & $\mathrm{F}, \mathrm{p}$ \\
\hline Invasion & $\mathbf{1}$ & $27.24,<0.001$ & $0.416,0.520$ & \multicolumn{2}{|c|}{$184.06,<0.001$} & \multicolumn{2}{|c|}{$1.339,0.249$} & $2.107,0.149$ \\
\hline Habitat & 1 & \multirow{2}{*}{$\begin{array}{l}32.51,<0.001 \\
1.48,0.226\end{array}$} & $0.156,0.694$ & \multicolumn{2}{|c|}{$2.192,0.141$} & \multicolumn{2}{|c|}{$4.92,0.028$} & $7.922,0.006$ \\
\hline Year & 1 & & $1.20,0.035$ & 1.01 & & & $377,0.173$ & \multirow{2}{*}{$\begin{array}{l}0.032,0.859 \\
0.022,0.978\end{array}$} \\
\hline Season & 2 & $19.03,<0.001$ & $1.804,0.168$ & \multicolumn{2}{|c|}{$2.941,0.056$} & \multicolumn{2}{|c|}{$3.787,0.025$} & \\
\hline \multirow{2}{*}{ (B) } & \multirow{2}{*}{ DF } & \multicolumn{2}{|c|}{ Bare Ground } & \multicolumn{3}{|c|}{ Aboveground Biomass } & \multicolumn{2}{|c|}{ Litter Biomass } \\
\hline & & $\mathrm{F}$ & $\mathrm{p}$ & $\mathrm{F}$ & $\mathrm{F}$ & & $\mathrm{p}$ & $\mathrm{p}$ \\
\hline Invasion & 1 & 83.28 & $<0.001$ & 127.34 & $<0.0$ & & 82.58 & $<0.001$ \\
\hline Habitat & 1 & 19.73 & $<0.001$ & 36.61 & $<0.0$ & & 1.531 & 0.216 \\
\hline Year & 1 & 0.015 & 0.902 & 23.20 & $<0.0$ & & 55.58 & $<0.001$ \\
\hline Season & 2 & 20.21 & $<0.001$ & 10.49 & $<0.0$ & & 223.18 & $<0.001$ \\
\hline
\end{tabular}

Table 2: Results from mixed general linear models for total arthropod abundance, biomass, richness and diversity. Bonferroni adjusted significant p-values are shown in bold.

\begin{tabular}{||l|c|c|c|c|c|c|}
\hline \hline & \multirow{2}{*}{ DF } & Abundance & Biomass & Richness & $\begin{array}{c}\text { Shannon } \\
\text { Diversity }\end{array}$ & $\begin{array}{c}\text { Shannon } \\
\text { Evenness }\end{array}$ \\
\cline { 3 - 7 } & & $\mathrm{F}, \mathrm{p}$ & $\mathrm{F}, \mathrm{p}$ & $\mathrm{F}, \mathrm{p}$ & $\mathrm{F}, \mathrm{p}$ & $\mathrm{F}, \mathrm{p}$ \\
\hline Invasion & 1 & $\mathbf{7 . 8 4 , 0 . 0 0 6}$ & $4.30,0.04$ & $\mathbf{1 7 . 4 0 ,}<\mathbf{0 . 0 0 1}$ & $\mathbf{8 . 5 2 , 0 . 0 0 4}$ & $0.197,0.657$ \\
Habitat & 1 & $\mathbf{9 . 8 2 , 0 . 0 0 2}$ & $0.37,0.54$ & $\mathbf{1 8 . 5 5 ,}<\mathbf{0 . 0 0 1}$ & $2.33,0.13$ & $0.389,0.533$ \\
Year & 1 & $\mathbf{2 6 . 7 2 ,}<\mathbf{0 . 0 0 1}$ & $0.47,0.49$ & $0.79,0.375$ & $0.09,0.76$ & $1.508,0.221$ \\
Season & 2 & $0.48,0.49$ & $3.01,0.05$ & $\mathbf{7 3 . 1 6 , < 0 . 0 0 1}$ & $\mathbf{7 8 . 7 5 , < 0 . 0 0 1}$ & $\mathbf{2 2 . 9 1 , < 0 . 0 0 1}$ \\
\hline
\end{tabular}

Table 3: Results from mixed general linear models for Trophic Group Abundance (A) and Biomass (B). Bonferroni adjusted significant p-values are shown in bold.

\begin{tabular}{|c|c|c|c|c|c|c|c|c|c|}
\hline \multirow{2}{*}{ (A) } & \multirow{2}{*}{ DF } & \multicolumn{2}{|c|}{ Carnivore } & \multicolumn{2}{|c|}{ Omnivore } & \multicolumn{2}{|c|}{ Herbivore } & \multicolumn{2}{|c|}{ Detritivore } \\
\hline & & $\mathrm{F}$ & $\mathrm{p}$ & $\mathrm{F}$ & $\mathrm{p}$ & $\mathrm{F}$ & $\mathrm{p}$ & $\mathrm{F}$ & $\mathrm{p}$ \\
\hline Invasion & 1 & 1.30 & 0.26 & 1.67 & 0.20 & 12.50 & 0.001 & 1.31 & 0.23 \\
\hline Habitat & 1 & 4.43 & 0.04 & 4.87 & 0.03 & 5.95 & 0.02 & 0.005 & 0.95 \\
\hline Year & 1 & 0.11 & 0.74 & 0.21 & 0.65 & 0.39 & 0.54 & 0.66 & 0.42 \\
\hline Season & 2 & 22.77 & $<0.001$ & 10.89 & $<0.001$ & 8.83 & 0.001 & 4.09 & 0.02 \\
\hline \multirow{2}{*}{ (B) } & \multirow{2}{*}{ DF } & \multicolumn{2}{|c|}{ Carnivore } & \multicolumn{2}{|c|}{ Omnivore } & \multicolumn{2}{|c|}{ Herbivore } & \multicolumn{2}{|c|}{ Detritivore } \\
\hline & & F & $\mathrm{p}$ & $\mathrm{F}$ & $\mathrm{p}$ & $\mathrm{F}$ & $\mathrm{p}$ & $\mathrm{F}$ & $\mathrm{p}$ \\
\hline Invasion & 1 & 4.09 & 0.05 & 1.50 & 0.23 & 18.82 & $<0.001$ & 0.03 & 0.87 \\
\hline Habitat & 1 & 0.11 & 0.74 & 0.01 & 0.91 & 446 & 0.04 & 0.007 & 0.93 \\
\hline Year & 1 & 2.20 & 0.15 & 0.03 & 0.97 & 0.48 & 0.62 & 2.03 & 0.14 \\
\hline Season & 2 & 3.78 & 0.03 & 0.84 & 0.37 & 0.55 & 0.46 & 1.87 & 0.18 \\
\hline
\end{tabular}


Table 4: Results from general mixed models for Guilds associated with significant Herbivore Abundance (A) and Herbivore Biomass (B). Bonferroni adjusted significant p-values are shown in bold

\begin{tabular}{||l|c|c|c|c|c|c|c|c|c|c||}
\hline \hline \multirow{2}{*}{$(\mathbf{A})$} & \multirow{2}{*}{$\mathrm{DF}$} & \multicolumn{2}{c|}{ Chewer Concealed } & \multicolumn{2}{c|}{ FL-Sap Feeder } & \multicolumn{2}{c||}{ FL-Chewer } & \multicolumn{2}{c||}{ Pollinator } \\
\cline { 3 - 10 } & & $\mathrm{F}$ & $\mathrm{p}$ & $\mathrm{F}$ & $\mathrm{p}$ & $\mathrm{F}$ & $\mathrm{p}$ & $\mathrm{F}$ & $\mathrm{p}$ \\
\hline Invasion & 1 & $\mathbf{1 0 . 0 5}$ & $\mathbf{0 . 0 0 3}$ & $\mathbf{7 . 3 1}$ & $\mathbf{0 . 0 1 0}$ & $\mathbf{1 1 . 1 1}$ & $\mathbf{0 . 0 0 2}$ & 3.20 & 0.08 \\
Habitat & 1 & $\mathbf{8 . 0 1}$ & $\mathbf{0 . 0 0 7}$ & 5.40 & 0.03 & 0.59 & 0.45 & 2.65 & 0.08 \\
Year & 1 & 0.32 & 0.57 & 0.99 & 0.33 & 0.40 & 0.53 & 1.17 & 0.29 \\
Season & 2 & $\mathbf{1 3 . 7 1}$ & $<\mathbf{0 . 0 0 1}$ & $\mathbf{5 . 8 5}$ & $\mathbf{0 . 0 0 6}$ & $\mathbf{6 . 0 9}$ & $\mathbf{0 . 0 0 5}$ & $\mathbf{5 . 4}$ & $\mathbf{0 . 0 0 8}$ \\
\hline
\end{tabular}



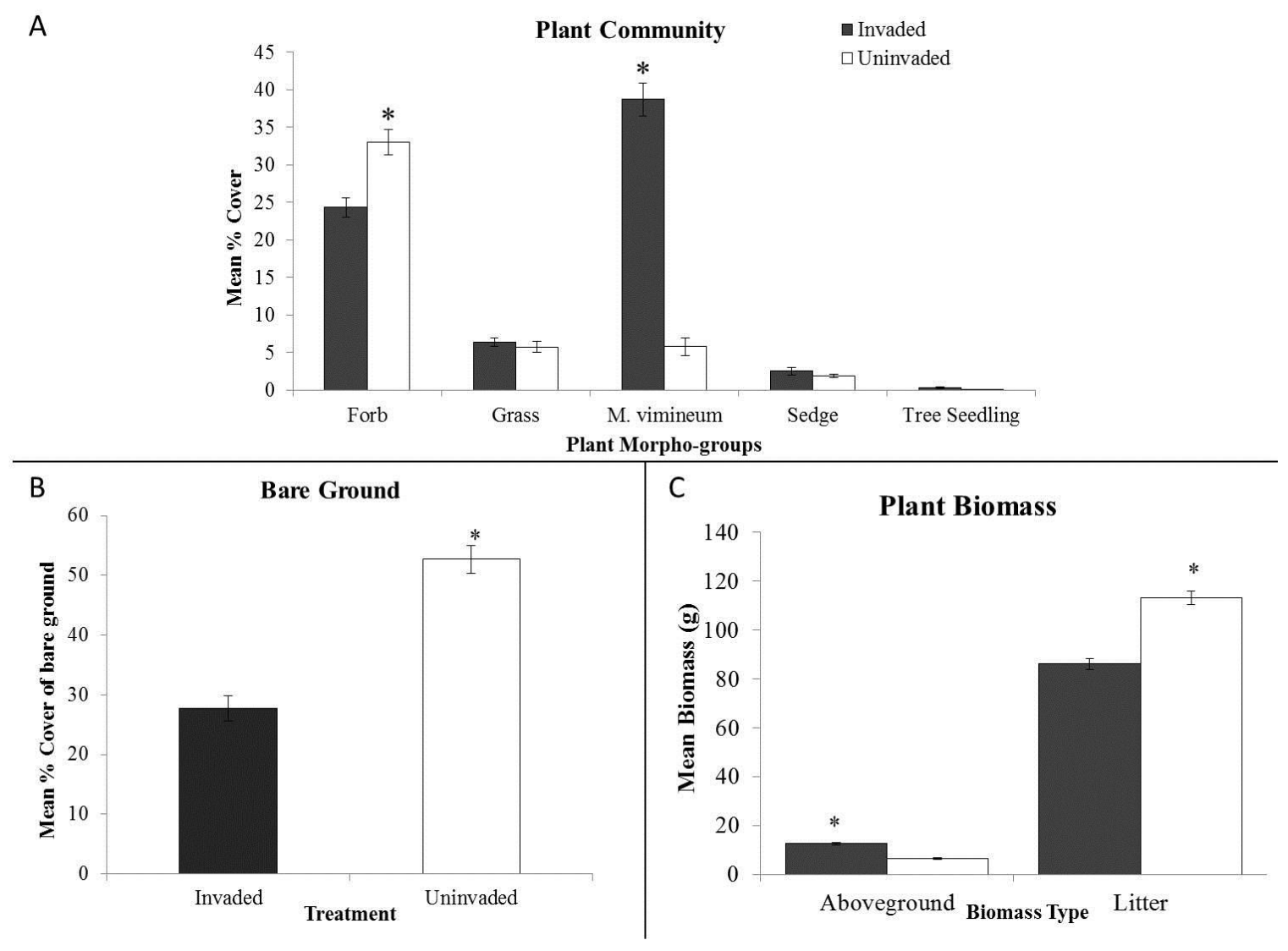

Figure 5: A) \% cover of forbs, non- $M$. vimineum grasses, $M$. vimineum, and sedges. B) $\%$ bare ground and C) Litter (g) and aboveground biomass (g). All variables were averaged across seasons and habitats for data collected from collected from Microstegium vimineum invaded (dark bars) and uninvaded (light bars) sites in 2010-2011. ${ }^{*}=\mathbf{p}<0.001$, Error bars are +/- S.E. 


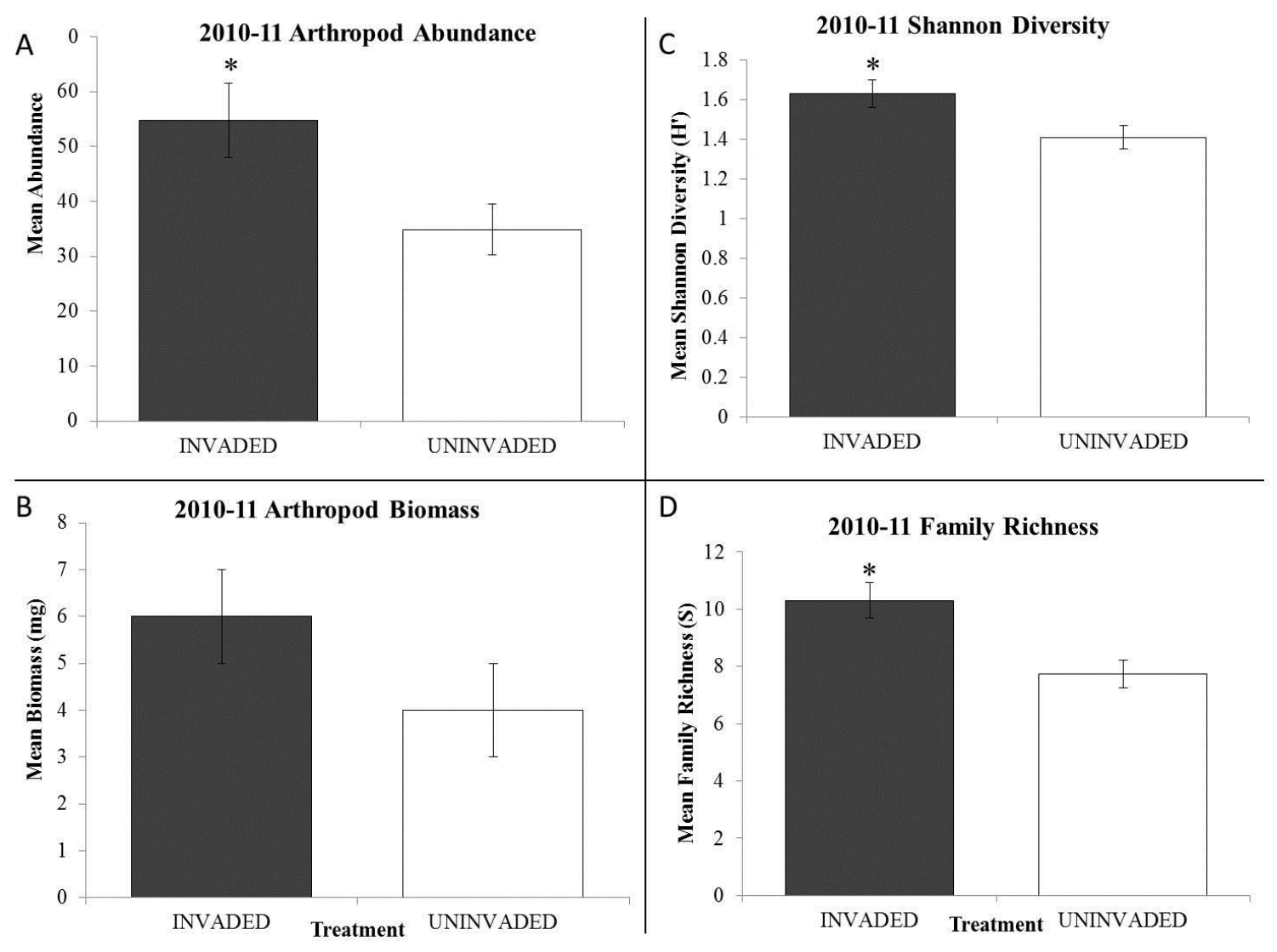

Figure 6: (A) Mean abundance of arthropods, (B) Mean Biomass (g), (C) Mean Shannon Diversity (H') and (D) Mean Family Richness (S) All variables were averaged across seasons and habitats for data collected using Sweep Nets from Microstegium vimineum invaded (dark bars) and uninvaded (light bars) sites in 2010-2011. $*=p<0.01$ (Bonferroni adjusted significance), Error bars are +/- S.E. 


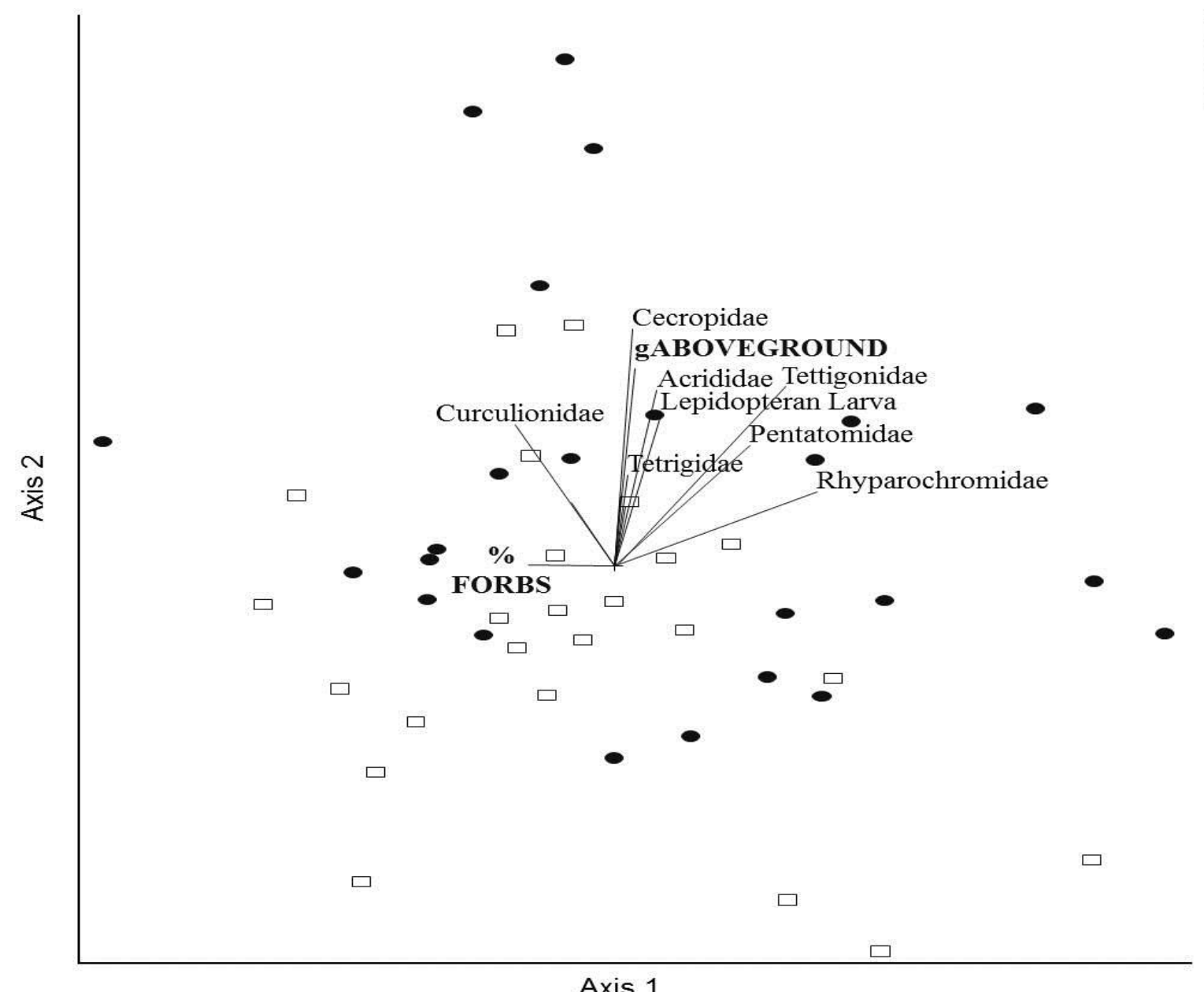




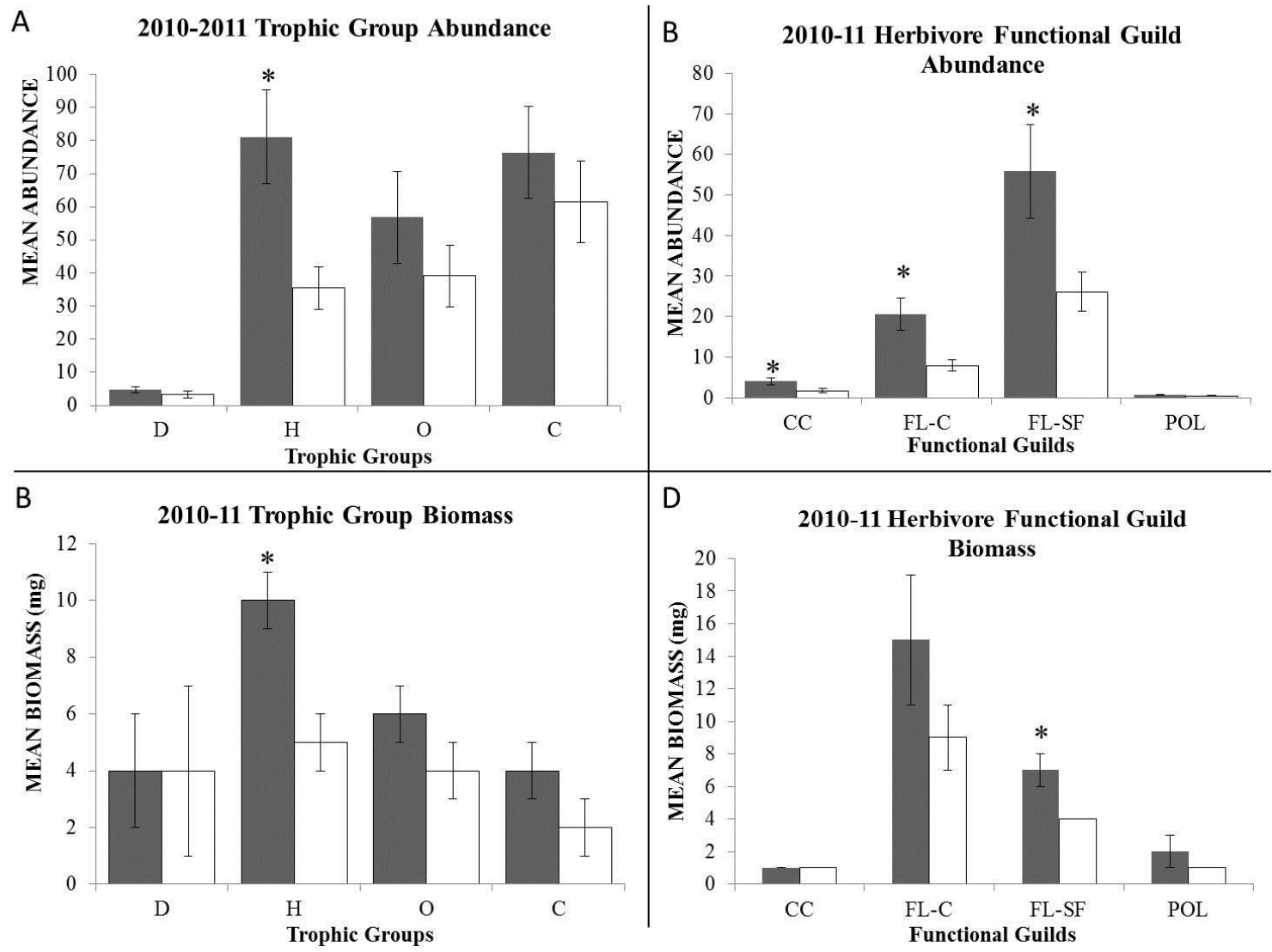

Figure 8: Trophic group A) mean abundance and B) mean biomass; C) Herbivore guild mean abundance and D) Herbivore guild mean biomass. (Gray bars = Invaded sites, open bars = uninvaded sites; $\mathrm{D}=$ Detritivore, $\mathrm{H}=$ Herbivore, $\mathrm{O}=$ Omnivore, $\mathrm{C}=$ Carnivore, $\mathrm{CC}=$ Concealed $\mathrm{Chewer}$, FL-C=Free-living Chewer, FL-SF=Free-living Sap Feeder, Poll=Pollinator). All variables were averaged across seasons and habitats for data collected using Sweep Nets from Microstegium vimineum invaded (dark bars) and uninvaded (light bars) sites in 2010-2011. $*=p<0.01$ (Bonferroni adjusted significance), Error bars are +/- S.E. 


\section{CHAPTER 3}

\section{CHANGES IN SPIDER COMMUNITY STRUCTURE ASSOCIATED WITH INVASION BY MICROSTEGIUM VIMINEUM}

\section{SUMMARY}

Spiders can have complex responses to invasive plants due to direct and indirect effects of invasions on food supplies (insects) and habitat. Because these invertebrate predators integrate both biotic and abiotic ecosystem changes, and occupy a wide variety of niches and habitats, spiders can serve as indicators of ecosystem health. In this study I evaluate the relationship between Microstegium vimineum, an invasive $\mathrm{C}_{4}$ grass that thrives in the understory of deciduous forests, and the abundance and community structure of spider communities. Mean abundance, richness and diversity increased in association with invasion by $M$. vimineum. These increases were seen in active hunter and sit-and-wait functional guilds, specifically in the Thomisidae, Salticidae, Oxyopidae and Pisauridae families. Ratios of adult: immature spiders were significantly lower in invaded sites. While the mechanism for this increase is impossible to determine without further study, our results indicate that spiders are likely responding to either increased structural complexity associated with invasion by $M$. vimineum, or to the increased prey availability (herbivores) associated with invasion in this system. These results indicate that invasion by $M$. vimineum could lead to increased spider abundances. 


\section{INTRODUCTION}

Many invasive plant species are known to have negative impacts on diversity, both for other plants as well as other trophic levels (Heleno et al. 2008, Adams and Engelhardt 2009, Haddad et al. 2009, Simao et al. 2010). However, the impacts of invasive plant species on higher trophic levels are somewhat understudied especially for predators such as spiders, which can have complex responses to invasive plants due to direct and indirect effects of invasions on food supplies (insects) and habitat (Finke and Denno 2002, Langellotto and Denno 2004, 2006, DeVore 2011). As invertebrate predators, and because of the extremely diverse set of niches and habitats occupied by spiders, the contribution these predators make to ecosystem function can be unique (Foelix 2011). The integration of both abiotic and biotic changes in the system via behavioral adaptations to vegetative structure and predation on lower trophic levels makes spiders useful as ecological indicators (Finke and Denno 2002, DeVore 2011, Foelix 2011). Indeed, changes in spider communities often indicate greater changes in the ecosystem that supports these predators (Mgobozi et al. 2008), so understanding the cascading effects of invasive plants on this trophic group becomes very important for ecologists and conservation biologists.

It has been widely shown that insect communities, especially herbivores, respond strongly to invasive plant species presence (Mgobozi et al. 2008, Cebrian et al. 2009, Yoshioka et al. 2010, Simao et al. 2010, Metcalf 2013a). Since insects make up the largest part of spider diets, I expect that changes in insect communities can have significant impacts on both the abundance and population demographics of these dominant predators (McCormick and Polis 1982). For example, Miyashita (1992) found that food serves as a limiting factor at both the individual and population levels for 
Nephila clavata, an orb-weaver in forest systems. Observational studies indicate that changes in available prey diversity in a system can significantly alter spider demographics, including survival rates of juveniles (Miyashita 1968, Vandyke \& Lowrie 1975, Riechert \& Harp 1987). For example, Uetz (1992) reared juvenile wolf spiders, collected from two separate locations (Highlands County, Florida and Kenton County, Kentucky) on different diets. Survivorship and age and size at maturity was directly related to dietary breadth, with higher diversity prey resources associated with increases in all of these important demographic variables. Such changes in population demographics, especially those parameters related to juveniles, can have serious impacts for predators such as the Lycosids, whose breeding population the following year is dependent on over-wintering juvenile survival (Scott et al. 2006).

Spiders also show considerable sensitivity to habitat disturbance and structure within ecosystems (Anderson 1990, Peck et al 1998). Changes in ground cover, aboveground biomass and vertical plant architecture have been shown to influence spider communities (McIver et al 1992, Lassau and Hochuli 2004, Pinkus-Rendon et al 2006). For example, Pearson (2010) found increases in densities of Dictyna spiders in areas where spotted knapweed, Centaurea maculosa, had invaded. Centaurea maculosa altered vegetative complexity and increased the availability of necessary web-building substrates that were limited in the absence of this invader. Different life stages of spiders can also show contrasting responses to vegetation structure. For example, Hallander (1970) reported a preference of two species of juvenile Pardosa for shaded habitat as compared to the adults of the same species that preferred habitats with greater sun exposure. Because spiders tend to travel relatively small distances, many exhibiting a very sedentary nature, they serve as an excellent basis for evaluating the impact of habitat 
changes that result from non-native plant invaders (Mgobozi et al 2008, Riechert 1974, Wise 1993, Pinkus-Rendon et al 2006).

While interest in spider responses to plant invasions is growing, most studies on invasive plant-spider interactions have evaluated effects on individual spider families or species (Pearson 2009, Pétillon et al. 2010a), while relatively little work has been done evaluating community-level effects of invasive plants on these dominant invertebrate predators (Parr et al. 2010, Simao et al. 2010; though see Bultman and DeWitt 2008). Understanding whole community effects, rather than single species effects, can give insight into shifts in functional group composition as well. Analysis of communities at the functional level is not uncommon and allows for evaluation of groups of organisms that exploit resources in the environment in similar ways, regardless of taxonomic relationships (Root 1967, Uetz 1977, Hatley and Macmahon 1980).

Spider communities are often categorized into functional groups based on hunting mode. Differences in hunting mode will often correspond with differences in prey choice as a result of differential susceptibility of prey to certain hunting methods including active hunting, web-building, and sit-and-wait predators (Uetz 1977, Bultman et al. 1982, Foelix 2011). These different functional groups coexist, playing unique roles in the community and their relative distributions can change depending on habitat characteristics. For example, active hunting spiders have been shown to make up as much as $43 \%$ of ground dwelling arthropods and comprise the majority of spider biomass in forest systems (Uetz 1977). Pajunen et al (1995) found higher numbers of ground dwelling spiders in mature forests, compared to younger managed forests with higher disturbance. Increases in vegetation complexity due to increased leaf litter and invasion by C. maculosa (spotted knapweed) were associated with increases in both cursorial 
spiders (Hallander 1970) and web-building spiders (Pearson 2009) respectively, which in turn can feed back to alter prey community structure.

In this study, I evaluated the associations between spider communities and the invasive grass Microstegium vimineum (Trin.) A. Camus. This annual $\mathrm{C}_{4}$ grass (Poaceae), also known as Japanese Stiltgrass, was accidentally introduced to the U.S. in the early 1900s as packing material (Fairbrothers and Gray 1972, Barden 1987), and is a prevalent invader throughout the eastern U.S. It is considered a species of concern due to its ability to thrive in the understory of deciduous forests, where it often outcompetes native forbs and grasses (Oswalt et al. 2007, Civitello et al. 2008, USDA 2008, Flory and Clay 2009, Adams and Engelhardt 2009, Flory 2010). Microstegium vimineum is an annual and early spring germinator that reaches peak biomass in late summer, produces high volumes of seed in early fall, and leaves behind a dense mat of litter (Barden 1987, Hunt and Zaremba 1992, Redman 1995). While M. vimineum has been shown to significantly impact plant community composition by reducing native plant diversity and biomass, its impacts on herbivorous insects and their invertebrate predators appear to be highly variable and context dependent (Barden 1987, Civitello et al. 2008, Flory and Clay 2009, Adams and Engelhardt 2009, Simao et al. 2010).

The goal of this study was to evaluate the associations of spiders with $M$. vimineum in a deciduous forest in Kentucky. In particular, I ask: 1) Do sites invaded by M. vimineum differ in spider abundance, diversity, and community composition compared to uninvaded sites? 2) Are there differences in spider demographics (developmental stage ratios) in $M$. vimineum invaded sites as compared to uninvaded sites? 3) Do spider functional guilds respond differently to $M$. vimineum invasion? 


\section{METHODS}

\section{Sampling Design}

This study was conducted at the University of Louisville Horner Wildlife Research Forest in Brownsboro, Kentucky $\left(38: 20: 27^{\circ} \mathrm{N}, 85: 31: 53.7^{\circ} \mathrm{W}\right)$. This is an 81 ha highly disturbed second-growth temperate deciduous forest in Northern Kentucky, with an upland area devoid of any natural permanent water source, and a lowland area bordering a stream. In May 2010, I established 24 transects, each $25 \mathrm{~m}$ long, in both upland (12 transects) and lowland (12 transects) habitats. Using a visual estimate of percent cover, within each habitat, six transects were located in 'invaded' sites $(>10 \% M$. vimineum, with invaded sited averaging $~ 48 \%$ M. vimineum) and 6 were located in 'uninvaded' sites (<10\% M.vimineum, with uninvaded sites averaging $~ 4 \% ~ M$. vimineum).

\section{Spider Collection}

Samples were collected once per month during two growing seasons (MayOctober 2010, 2011) using pitfall traps and sweep nets. One pitfall trap was placed every $5 \mathrm{~m}$ along the length of each transect, for a total of 4 pitfall traps per transect. Traps were made using $10.16 \mathrm{~cm}$ diameter PVC pipe cut to $10.16 \mathrm{~cm}$ long and placed flush into predug holes in the soil. Traps were set by placing empty $0.24 \mathrm{~L}$ plastic cups into the PVC. After 48 hours the cups were removed from the PVC and samples were pooled and emptied into zip-top bags for transport back to the lab. Two 1 m wide sweep net samples (15 sweeps per sample) were collected along each transect. Sweep net samples were pooled for each transect, transferred to zip-top bags and returned to the lab. Spiders were sorted from other arthropods and transferred to glass vials containing $70 \%$ ethanol for preservation. 
Spiders were identified to genus and developmental stage (immature, adult) using Ubick (2005). Spider families were assigned to a functional guild based on common hunting strategies (see appendix II) (Uetz 1977, Bultman et al. 1982, Uetz et al. 1999, Foelix 2011). I calculated both total abundance as well as relative abundance of each functional guild for analyses.

\section{Data Analysis}

I conducted a two-factor mixed model ANOVA with habitat as a random factor, invasion status as a fixed factor, and year and season as covariates on data from the 24 transects to compare the associations of invasion with spider abundance, diversity and evenness, and developmental stage. The community composition and functional groups that are typically collected using pitfall traps and sweep nets are different from one another. Therefore these trap types were analysed separately. Shannon diversity and evenness indices (Shannon 1948) were calculated using spider abundance values. Analyses were completed at the family and genus levels as well as by functional guild. Response data were $\ln ($ abundance +1$)$ transformed as necessary to improve normality. ANOVA analyses were conducted using Systat v. 13 (2009).

Multi-response permutation procedures (MRPP) with a Euclidean distance measure (Zimmerman et al. 1985) were used to compare spider community composition at both the family and genus level found with each sampling method between invaded and uninvaded sites. Within group homogeneity is reported as A, with values ranging from -1 (highest heterogeneity) to 1 (totally homogenous). MRPP is similar to multivariate analysis of variance (MANOVA) but does not rely on the assumptions of normality, which is rare in community data such as these. To better visualize the differences in family and genus composition between invaded and uninvaded sites, I used 
Nonmetric Multidimensional Scaling (NMS) (McCune and Grace 2002) with Bray-Curtis dissimilarity measures. I only analysed sweep net diversity data using NMS due to the relatively low abundances found in pitfall traps. NMS is an ordination technique similar to Principal Components Analysis, but uses ranked distance between plots to estimate similarity to avoid assumptions about linearity or unimodality of the community data. This analysis is well suited for ecological community data as they tend to be non-normal and discontinuous (McCune and Grace 2002). For this analysis, I used a random starting configuration with 250 runs with real data and 250 runs with simulated data. PCORD v 5.10 (McCune and Mefford 1999) was used for the MRPP and NMS analysis.

\section{RESULTS}

\section{Spider Abundance and Diversity}

In 2010 and 2011, 1925 spiders, comprising 21 families and 64 genera, were collected and identified using pitfall traps (325 spiders) and sweep nets (1600 spiders). Both sampling methods showed increased spider abundance associated with M. vimineum invasion, although pitfall traps were only marginally significant $(\mathrm{p}=0.03, \mathrm{~F}=4.57)$ after Bonferroni correction (Table 5A, Fig. 9A). Spiders captured using pitfall traps were 64\% more abundant in invaded sites while sweep-net captured spiders were 99\% more abundant. Family richness was 56\% higher in pitfall traps and $45 \%$ higher in sweep nets in invaded sites (Table 5B, Fig. 9B). Genus richness was 70\% higher in pitfall traps and 46\% higher in sweep nets in invaded sites (Table 5C, Fig. 9C). Sweep net samples contained 29\% higher genus diversity associated with invasion by M. vimineum (Table 5C, Fig. 9D). There were no associations between invasion and spider community evenness at either family or genus level. 
Invaded sites differed from uninvaded sites in family composition for both pitfall (MRPP: $\mathrm{p}=0.02 ; \mathrm{A}=0.02$ ) and sweep net collections (MRPP: $\mathrm{p}<0.01 ; \mathrm{A}=0.03$ ). NMS analysis for sweep net families indicated that sites were most clearly defined by Axis 1 (Fig. 10A, $\mathrm{R}^{2}=0.46$ ). Invasion by $M$. vimineum was generally associated with increases in Oxyopidae (lynx spiders $-454 \%$ ), Pisauridae (nursery web spiders $-255 \%$ ), Salticidae (jumping spiders $-124 \%$ ), and Thomisidae (crab spiders - 83\%).

Invaded sites also differed from uninvaded sites in spider genus-level composition for both pitfall (MRPP: $\mathrm{p}=0.04, \mathrm{~A}=0.01$ ) and sweep net (MRPP: $\mathrm{p}<0.001 ; \mathrm{A}=0.02$ ). The NMS analysis for sweep net genera indicated that sites were most clearly defined by Axis 1 (Fig. 10B, $\mathrm{R}^{2}=0.56$ ). Invasion by $M$. vimineum for sweep net samples was generally associated with increases in: Oxyopidae: Oxyopes (453\%); Pisauridae: Pisaurina (255\%); Thomisidae: Mecaphesa (91\%); and Salticidae: Eris (142\%), Sassacus (138\%), Thiodina $(147 \%)$.

\section{Spider Population Demographics}

There was a significant association between $M$. vimineum presence and ratios of adult:immature spiders in sweep net samples (Table 6, Fig. 11). The ratio of adult:immature spiders was $12.4 \%$ lower in invaded sites than in uninvaded. There was no significant association between invasion status and the ratio of adult:immature spiders in pitfall samples (Table 6, Fig. 11).

\section{Spider Functional Guilds}

In sweep net samples, ambush predators were the only guild to show significant differences between invaded and uninvaded treatments after Bonferroni correction (Table 7A, Fig 12A). Ambush spider abundance was 43\% higher in M. vimineum invaded than uninvaded sites. In pitfall trap samples, no functional groups were significantly different 
after Bonferroni correction (Table 7B, Fig. 12B). Web builder abundance did not differ greatly in either the sweep nets or pitfall traps. In sweep net samples, the percentage of ambush predators was significantly higher in invaded sites, although this significance was lost after Bonferroni correction (Table 7C, Fig. 13A,). In pitfall samples, the percent of ground runner spiders was significantly higher in uninvaded site; however this significance was lost after Bonferroni correction (Table 7D), Fig 13B).

\section{DISCUSSION}

While significant research has been conducted evaluating the effects of Microstegium vimineum on plant (Barden 1987, Oswalt et al. 2007, Flory 2010) and insect communities (Civitello et al. 2008, Marshall and Buckley 2009, Simao et al. 2010, Tang et al. 2012), research evaluating associations between this invasive grass and changes in the overall structure of the spider community are lacking (Simao et al. 2010). Because spiders are important indicators of ecosystem health, understanding the associations between invasion by $M$. vimineum and changes in the spider community can help provide insights into changes in the ecosystem (Foelix 2011).

\section{Do sites invaded by M. vimineum differ in terms of spider abundance, diversity and community composition compared to uninvaded sites?}

The results of this study clearly indicate an increase in the abundance of spiders associated with $M$. vimineum invasion across both sampling methods, as well as increases in diversity and evenness at both the family and genus level. These increases coincide with increases in above-ground biomass and insect herbivore abundance and biomass (Metcalf 2013a).

There were also differences in spider community composition between invaded and uninvaded sites. Thomisidae, Salticidae, Oxyopidae and Pisauridae were the families 
with the most significant increases in abundance associated with $M$. vimineum invasion. Intra-guild predation is relatively common among these families (Hallander 1970, Langellotto and Denno 2004, 2006). The increased abundance of these families likely resulted from the increased structural complexity provided by $M$. vimineum which could potentially decreasing intra-guild predation success rates.

This study adds to the relatively limited body of literature evaluating the impacts of M. vimineum on arthropod communities. Currently the consensus on the impacts of this invasive grass on arthropods is believed to be context dependent, with certain invaded communities demonstrating increases (Marshall and Buckley 2009, Tang et al. 2012, Metcalf 2013a) and others demonstrating decreases (Simao et al. 2010) in overall arthropod abundance associated with $M$. vimineum. If spider communities are responding to changes in herbivore prey abundance, I would expect to see a similar contextdependent response by the spider communities to $M$. vimineum invasion. For example, Simao et al (2010) found that decreases in insect herbivore abundance were associated with decreases in spider abundance in M. vimineum invasions in Indiana.

Our study actually shows a positive impact of plant invasion on spider communities. This effect has been demonstrated in other plant invasions in both terrestrial and estuarine systems. Increased structural complexity associated with invasion by Elymus athericus in European salt marshes let to increased abundance and survival of cursorial spiders during inundation floods (Pétillon et al. 2010b, 2010a). In a M. vimineum invasion in the Georgia Piedmont, DeVore (2011) found significant associations between increased structural complexity and increases in spider abundances, particularly Lycosids (wolf spiders). 
Are there differences in spider demographics in M. vimineum invaded sites as compared to uninvaded sites?

I found significantly lower ratios of adults to immature spiders in invaded sites within the sweep net samples. There were no significant differences in the ratios of adults to immature spiders in the pitfall samples. Juvenile survivorship positively correlated with prey diversity (Uetz et al. 1992), and higher insect abundance and diversity are associated with invasion by $M$. vimineum in this system (Metcalf 2013a), providing one potential explanation for juveniles being more common in invaded sites. Intra-guild predation (cannibalism) would be an additional mechanism that could be driving the differences in the adult:immature ratios between treatments. Since cannibalism, particularly adults preying on juveniles, among spiders is common, and increased structural complexity can reduce the effects of cannibalism and intra guild predation, it is likely that the increased adult:immature ratio in uninvaded sites is related to the reduced structural complexity in these sites (Hallander 1970, Uetz et al. 1992).

\section{Do spider functional guilds respond differently to M. vimineum invasion?}

Only one spider functional guild (ambushers) evaluated showed significant increases in abundance associated with $M$. vimineum invasion after correcting for multiple analyses. This guild includes families of spiders that would be expected to benefit from the added cover provided by increased biomass that accompanies $M$. vimineum invasion (see appendix II). Increases in this guild are expected in plant invasions that increase structural complexity, as it reduces the impact on intra-guild predation and cannibalism between these groups; however web building spiders may suffer from higher levels of intra-guild predation in these sites when the families associated with ambush spider abundances are higher (Finke and Denno 2002, 2006, 
Langellotto and Denno 2004, Denno et al. 2004). Structural complexity has been shown to decrease the effects of intra-guild predation which is common in spiders (Finke and Denno 2002, Langellotto and Denno 2004).

The lack of structural complexity impact on all types of web-builders was surprising in light of the work by Pearson (2009) in which Dictyna spiders increased as a result of increased structural complexity associated with C. maculosa. However, the attachment sites provided by this larger woodier invasive would be more stable, and thus more beneficial to web-building spiders than the attachment sites provided by the smaller, herbaceous M. vimineum.

There were significant associations between habitat, season and year for many of the response variables I addressed (abundance, diversity and richness, functional guild abundance, adult:immature ratio). Spider abundance was higher in the lowland habitat than in the upland habitat. This is likely a function of the slightly higher plant biomass present in the lowland sites related to the nearby stream that borders this habitat. Seasonal differences are common and generally relate to the life history of spiders following closely the insect prey populations that also show a seasonal response to plant productivity. For most spider response variables, fall had significantly lower numbers than spring and summer with the exception of the ratio of adult:immature spiders. These were highest in the fall, likely as a function of immature spiders preparing to overwinter below the leaf litter making them less likely to be captured in sweep net samples (Cramer and Maywright 2008). Yearly variation indicated higher spider abundance, diversity, functional guild abundance and adult:immature ratios in 2010 than 2011. Late fall and early winter temperatures were higher (by 11\%) in 2009 than 2010, which may have increased survivorship of nymph and juvenile spiders over the winter, thus increasing the 
adult spider abundance in the following year (Cramer and Maywright 2008, NOAA 2009, 2010).

Based on our current study, it is impossible to separate the exact mechanisms by which M. vimineum presence can increase spider abundance and diversity; further manipulative experiments would be needed to address this. However, as the predominant invertebrate predator in terrestrial systems, spiders play a vital role in the control of insect populations and in the transfer of energy from primary consumers to higher vertebrates. If changes in the spider abundances are due to increased structural complexity rather than increased insect herbivore presence, I might expect increased spider numbers to have significant feedbacks on herbivore communities over time (Denno et al. 2002, Finke and Denno 2002, Langellotto and Denno 2004). More detailed studies evaluating the changes in and consequences of spider community structure due to plant invasion are needed. 
Table 5: Results from mixed general linear models for total A) Total abundance B) Family richness, diversity and evenness C) Genus richness, diversity and evenness for sweep net and pitfall communities. Bonferroni adjusted significant p-values are shown in bold.

\begin{tabular}{|c|c|c|c|c|c|c|c|}
\hline \multirow{2}{*}{ (A) } & \multirow{2}{*}{ DF } & \multicolumn{3}{|c|}{ Sweep Net } & \multicolumn{3}{|c|}{ Pitfall } \\
\hline & & \multicolumn{3}{|c|}{$\mathrm{F}, \mathrm{p}$} & \multicolumn{3}{|c|}{$\mathrm{F}, \mathrm{p}$} \\
\hline Invasion & 1 & \multicolumn{3}{|c|}{$20.12,<0.001$} & \multicolumn{3}{|c|}{$4.57,0.03$} \\
\hline Habitat & 1 & \multicolumn{3}{|c|}{$12.75,<0.001$} & \multicolumn{3}{|c|}{$3.74,0.05$} \\
\hline Year & 1 & \multicolumn{3}{|c|}{$19.8,<0.001$} & \multicolumn{3}{|c|}{ 7.06, 0.01} \\
\hline Season & 2 & \multicolumn{3}{|c|}{$19.31,<0.001$} & \multicolumn{3}{|c|}{$8.26,<0.01$} \\
\hline \multirow{3}{*}{ (B) } & \multirow{3}{*}{ DF } & \multicolumn{3}{|c|}{ Sweep Net } & \multicolumn{3}{|c|}{ Pitfall } \\
\hline & & Richness & Diversity & Evenness & Richness & Diversity & Evenness \\
\hline & & $\mathrm{F}, \mathrm{p}$ & $F, p$ & $\mathrm{~F}, \mathrm{p}$ & $F, p$ & $\mathrm{~F}, \mathrm{p}$ & $\mathrm{F}, \mathrm{p}$ \\
\hline Invasion & 1 & $15.78,<0.001$ & $0.24,0.63$ & $1.57,0.21$ & $8.11,<0.01$ & $3.1,0.08$ & $0.99,0.32$ \\
\hline Habitat & 1 & $21.28,<0.001$ & $2.77,0.1$ & 7.4, 0.007 & $2.84,0.09$ & $1.36,0.25$ & $1.93,0.17$ \\
\hline Year & 1 & 43.36, <0.001 & $4.16,0.04$ & $28.83,<0.001$ & $10.98,0.001$ & $8.14,0.005$ & $3.94,0.05$ \\
\hline Season & 2 & $88.93,<0.001$ & $1.04,0.35$ & $13.19,<0.001$ & $9.3,<0.001$ & $5.98,0.003$ & $4.55,0.01$ \\
\hline \multirow{3}{*}{ (C) } & \multirow{3}{*}{$\begin{array}{l}\text { D } \\
\text { F }\end{array}$} & \multicolumn{3}{|c|}{ Sweep Net } & \multicolumn{3}{|c|}{ Pitfall } \\
\hline & & Richness & Diversity & Evenness & Richness & Diversity & Evenness \\
\hline & & $F, p$ & $\mathrm{~F}, \mathrm{p}$ & $\mathrm{F}, \mathrm{p}$ & $F, p$ & $\mathrm{~F}, \mathrm{p}$ & $\mathrm{F}, \mathrm{p}$ \\
\hline Invasion & 1 & $16.88,<0.001$ & $9.13,0.003$ & $1.36,0.24$ & $8.9,0.003$ & $3.1,0.08$ & $1.21,0.27$ \\
\hline Habitat & 1 & $2.12,0.15$ & $0.48,0.49$ & $3.68,0.06$ & $4.23,0.04$ & $3.19,0.08$ & $2.66,0.1$ \\
\hline Year & 1 & $23.08,<0.001$ & $24.82,<0.001$ & $11.35,0.001$ & $10.17,0.002$ & 7.36, 0.007 & $2.49,0.12$ \\
\hline Season & 2 & $17.42,<0.001$ & $15.79,<0.001$ & $11.33,<0.001$ & $9.52,<0.001$ & $7.45,0.001$ & $5.56,0.004$ \\
\hline
\end{tabular}

Table 6: Results from mixed general linear models for ratios of adult:immature developmental stages for both sweep net and pitfall trap communities.

\begin{tabular}{|c|c|c|c|c|c|}
\hline & \multirow[t]{2}{*}{ DF } & \multicolumn{2}{|c|}{$\begin{array}{c}\text { adult:immature } \\
\text { Sweep Net Community }\end{array}$} & \multicolumn{2}{|c|}{$\begin{array}{c}\text { adult:immature } \\
\text { Pitfall Community }\end{array}$} \\
\hline & & $\mathrm{F}$ & $\mathrm{P}$ & $\mathrm{F}$ & $\mathrm{p}$ \\
\hline Invasion & 1 & 8.083 & 0.005 & 2.232 & 0.136 \\
\hline Habitat & 1 & 3.259 & 0.072 & 8.977 & 0.003 \\
\hline Year & 1 & 17.199 & $<0.001$ & 6.317 & 0.013 \\
\hline Season & 2 & 4.027 & 0.019 & 9.788 & $<0.001$ \\
\hline
\end{tabular}


Table 7: Results from mixed general linear models for functional guild total abundance for A) Sweep Net Abundance and B) Pitfall trap Abundance; and functional guild relative abundance for C) Sweep Net and D) Pitfall Trap. Bonferroni adjusted significant p-values are shown in bold.

\begin{tabular}{|c|c|c|c|c|c|c|c|c|c|}
\hline \multirow[t]{2}{*}{ (A) } & \multirow[t]{2}{*}{ DF } & Ambusher & $\begin{array}{l}\text { Foliage } \\
\text { Runner }\end{array}$ & $\begin{array}{l}\text { Ground } \\
\text { Runner }\end{array}$ & Orb Weaver & $\begin{array}{c}\text { Sheet Web } \\
\text { Builder }\end{array}$ & $\begin{array}{c}\text { Space web } \\
\text { Builder }\end{array}$ & Stalker & $\begin{array}{c}\text { Wandering } \\
\text { Sheet Weaver }\end{array}$ \\
\hline & & $\mathrm{F}, \mathrm{p}$ & $\mathrm{F}, \mathrm{p}$ & $\mathrm{F}, \mathrm{p}$ & $\mathrm{F}, \mathrm{p}$ & $\mathrm{F}, \mathrm{p}$ & $\mathrm{F}, \mathrm{p}$ & $\mathrm{F}, \mathrm{p}$ & $\mathrm{F}, \mathrm{p}$ \\
\hline Invasion & 1 & $14.8,<0.001$ & $2.5,0.12$ & $0.71,0.40$ & $0.001,0.97$ & $0.41,0.53$ & $1.72,0.20$ & $6.00,0.02$ & $1.67,0.2$ \\
\hline Habitat & 1 & $0.742,0.390$ & $2.67,0.13$ & $3.11,0.08$ & $6.41,0.01$ & $1.39,0.26$ & $2.2,0.15$ & $0.49,0.49$ & $0.68,0.41$ \\
\hline Year & 1 & 7.451,0.007 & $0.29,0.59$ & $0.12,0.73$ & $3.57,0.06$ & $1.33,0.27$ & $0.33,0.57$ & $0.05,0.83$ & $0.95,0.33$ \\
\hline Season & 2 & $11.793,<0.001$ & $0.38,0.69$ & $0.97,0.38$ & $0.38,0.68$ & $0.97,0.34$ & $0.34,0.72$ & $6.61,0.002$ & $1.05,0.36$ \\
\hline
\end{tabular}

\begin{tabular}{||l|c|c|c|c|c|}
\hline \multicolumn{1}{||}{$(\mathrm{B})$} & DF & Ambusher & $\begin{array}{c}\text { Ground } \\
\text { Runner }\end{array}$ & Stalker & $\begin{array}{c}\text { Wandering } \\
\text { Sheet Weaver }\end{array}$ \\
\cline { 3 - 6 } & & $\mathrm{F}, \mathrm{p}$ & $\mathrm{F}, \mathrm{p}$ & $\mathrm{F}, \mathrm{p}$ & $\mathrm{F}, \mathrm{p}$ \\
\hline Invasion & 1 & $0.14,0.72$ & $0.74,0.39$ & $0.28,0.60$ & $0.18,0.68$ \\
Habitat & 1 & $0.67,0.42$ & $2.21,0.14$ & $0.37,0.55$ & $1.63,0.22$ \\
Year & 1 & $1.80,0.18$ & $2.21,0.11$ & $0.78,0.84$ & $0.63,0.55$ \\
Season & 2 & $0.11,0.75$ & $0.09,0.77$ & $\mathbf{2 4 . 5 1 , < 0 . 0 0 1}$ & $0.37,0.56$ \\
\hline
\end{tabular}

\begin{tabular}{|c|c|c|c|c|c|c|c|c|c|}
\hline \multirow[t]{2}{*}{ (C) } & \multirow[t]{2}{*}{ DF } & Ambusher & $\begin{array}{l}\text { Foliage } \\
\text { Runner }\end{array}$ & $\begin{array}{l}\text { Ground } \\
\text { Runner }\end{array}$ & Orb Weaver & $\begin{array}{c}\text { Sheet Web } \\
\text { Builder }\end{array}$ & $\begin{array}{c}\text { Space web } \\
\text { Builder }\end{array}$ & Stalker & $\begin{array}{c}\text { Wandering } \\
\text { Sheet Weaver }\end{array}$ \\
\hline & & $\mathrm{F}, \mathrm{p}$ & $\mathrm{F}, \mathrm{p}$ & $\mathrm{F}, \mathrm{p}$ & $\mathrm{F}, \mathrm{p}$ & $\mathrm{F}, \mathrm{p}$ & $\mathrm{F}, \mathrm{p}$ & $\mathrm{F}, \mathrm{p}$ & $\mathrm{F}, \mathrm{p}$ \\
\hline Invasion & 1 & $4.76,0.03$ & $2.62,0.11$ & $0.66,0.42$ & $0.004,0.95$ & $1.48,0.23$ & $0.006,0.94$ & $0.40,0.53$ & $1.65,0.20$ \\
\hline Habitat & 1 & $0.12,0.73$ & $2.54,0.113$ & $0.70,0.41$ & $2.55,0.11$ & $0,0.99$ & $0.36,0.55$ & $0.46,0.50$ & $2.57,0.11$ \\
\hline Year & 1 & $0.11,0.75$ & $0.60,0.44$ & $0.05,0.82$ & $0.06,0.81$ & $0.09,0.77$ & $8.92,0.003$ & $5.52,0.02$ & $1.11,0.29$ \\
\hline Season & 2 & $1.47,0.23$ & $10.07,<0.001$ & $2.03,0.13$ & $7.2,0.001$ & $1.81,0.17$ & $2.2,0.11$ & $14.58,<0.001$ & $3.94,0.02$ \\
\hline
\end{tabular}

\begin{tabular}{|c|c|c|c|c|c|c|c|c|c|}
\hline \multirow[t]{2}{*}{ (D) } & \multirow[t]{2}{*}{ DF } & Ambusher & $\begin{array}{l}\text { Foliage } \\
\text { Runner }\end{array}$ & $\begin{array}{l}\text { Ground } \\
\text { Runner }\end{array}$ & $\begin{array}{c}\text { Orb } \\
\text { Weaver }\end{array}$ & $\begin{array}{c}\text { Sheet Web } \\
\text { Builder }\end{array}$ & $\begin{array}{c}\text { Space web } \\
\text { Builder }\end{array}$ & Stalker & $\begin{array}{c}\text { Wandering } \\
\text { Sheet Weaver }\end{array}$ \\
\hline & & $\mathrm{F}, \mathrm{p}$ & $\mathrm{F}, \mathrm{p}$ & $\mathrm{F}, \mathrm{p}$ & $\mathrm{F}, \mathrm{p}$ & $\mathrm{F}, \mathrm{p}$ & $\mathrm{F}, \mathrm{p}$ & $\mathrm{F}, \mathrm{p}$ & $\mathrm{F}, \mathrm{p}$ \\
\hline Invasion & 1 & $0.03,0.87$ & $2.38,0.13$ & $4.34,0.04$ & $0.37,0.55$ & $0.02,0.90$ & $0.02,0.89$ & $2.10,0.15$ & $1.14,0.29$ \\
\hline Habitat & 1 & $7.52,0.007$ & $0.08,0.78$ & $3.91,0.05$ & $2.99,0.09$ & $0.27,0.60$ & $2.08,0.15$ & $0.001,0.98$ & $0.18,0.67$ \\
\hline Year & 1 & $0.37,0.55$ & $9.52,0.002$ & $22.70,<0.001$ & $0.21,0.65$ & $2.20,0.14$ & $1.38,0.24$ & $12.68,0.001$ & $4.34,0.04$ \\
\hline Season & 2 & $2.12,0.13$ & $2.93,0.06$ & $1.78,0.17$ & $4.09,0.02$ & $2.28,0.11$ & $0.92,0.40$ & $0.53,0.59$ & $1.74,0.18$ \\
\hline
\end{tabular}




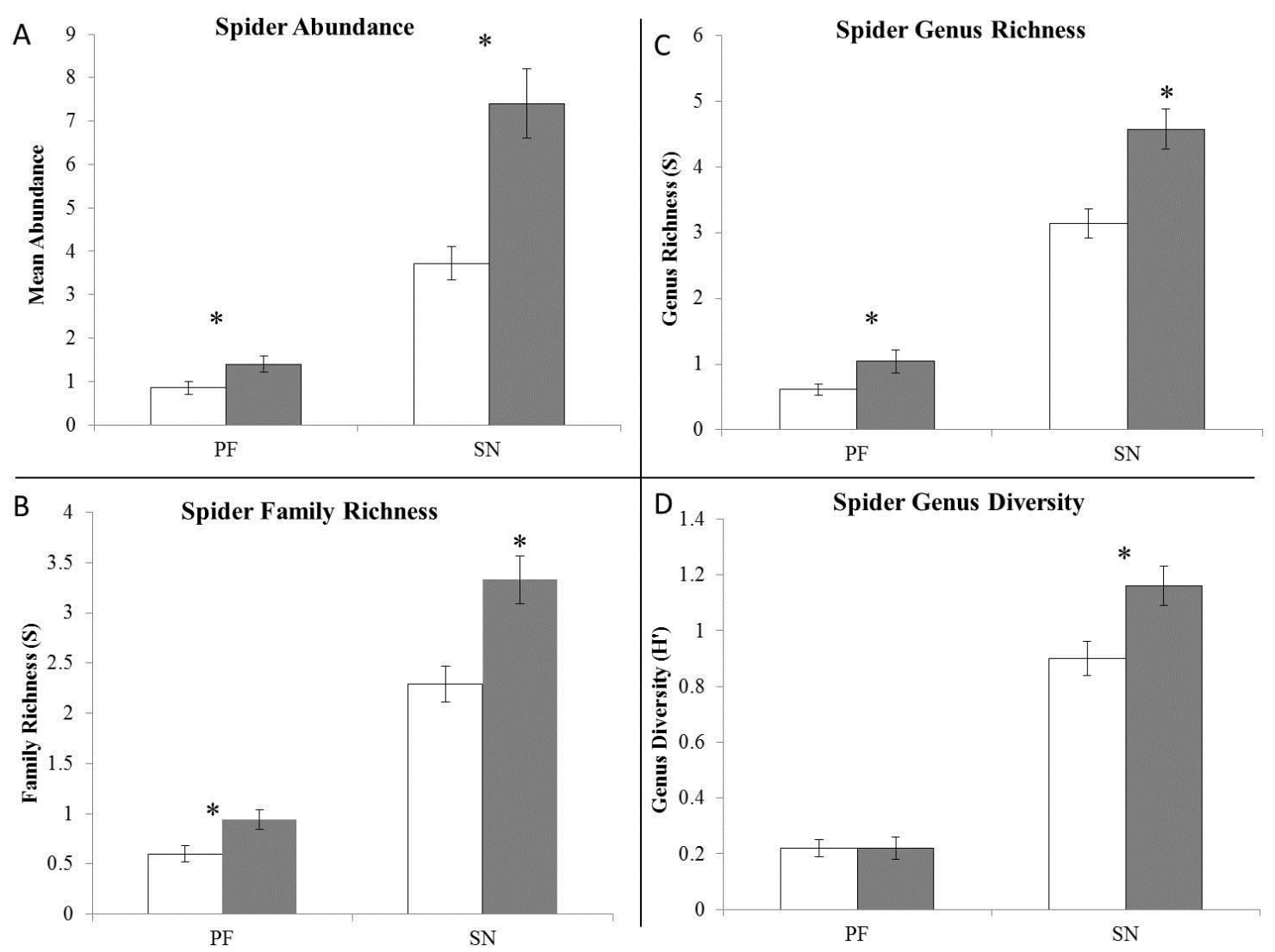

Figure 9: A) Mean abundance of spiders in sites invaded with $M$. vimineum (dark bars) and sites uninvaded by this grass (light bars), B) Mean Family Richness (S), C) Mean Genus Richness (S) and D) Mean Genus Shannon Diversity (H') collected for both pitfall (PF) and sweep net $(\mathrm{SN})$ trapping in 2010-2011. * $=$ p<0.01 (Bonferroni adjusted significance), Error bars are +/- S.E. 


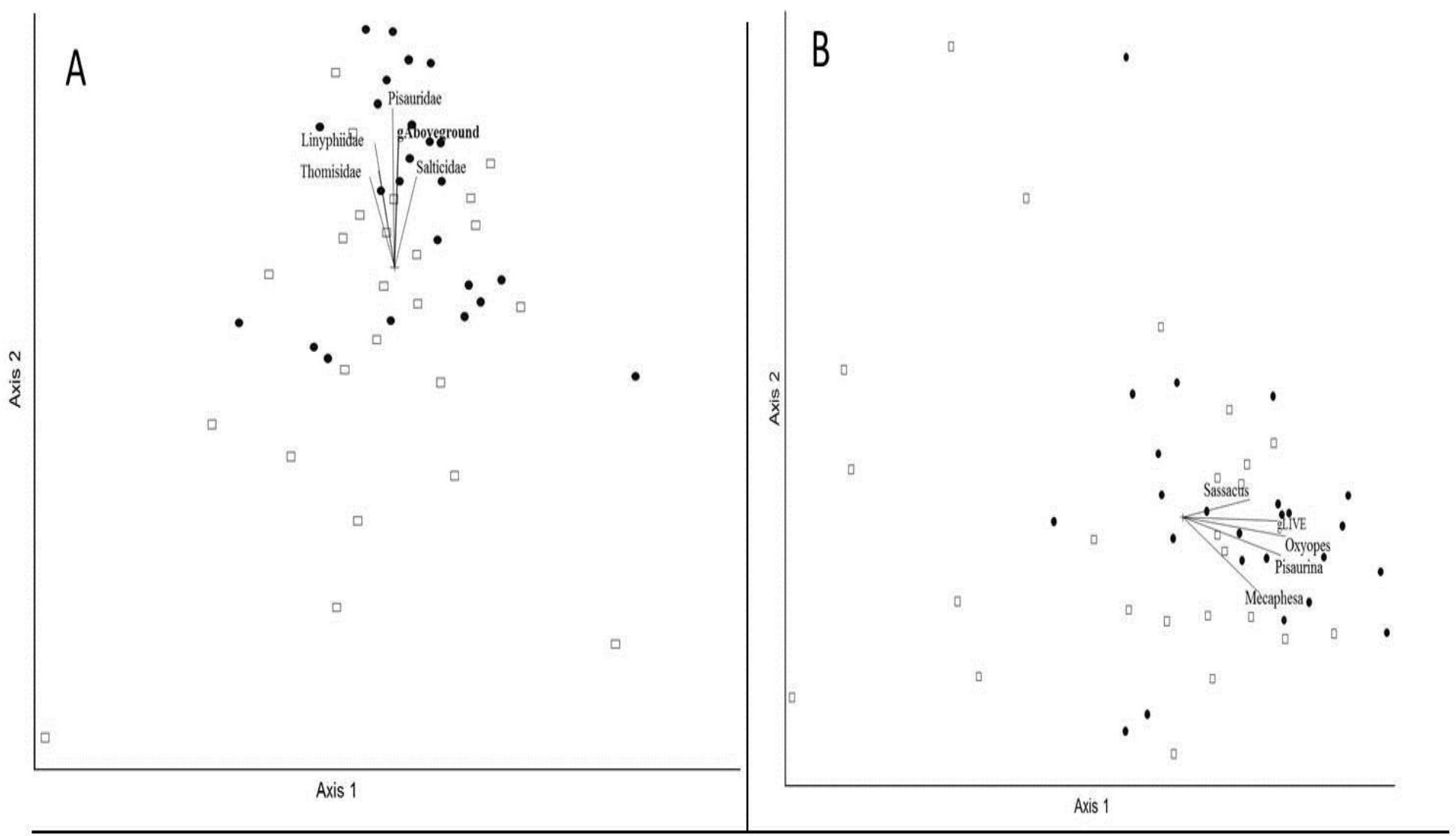

Figure 10. Results of NMS analysis using Sorenson Distance measure, open squares are uninvaded sites, dark circles are invaded sites. A) Sweep net families with a final stress of 18.54 after 250 runs with real data and 500 iterations for the final solution. Axis 1 explained $46 \%$ of the variation in the data while Axis 2 explained 34.8\%. B) Sweep net genera (Salticidae and Thomisidae families) with a final stress of 21.47 after 250 runs with real data and 500 iterations for the final solution. Axis 1 explained 58.5\% of the variation in the data while Axis 2 explained $17.3 \%$. 


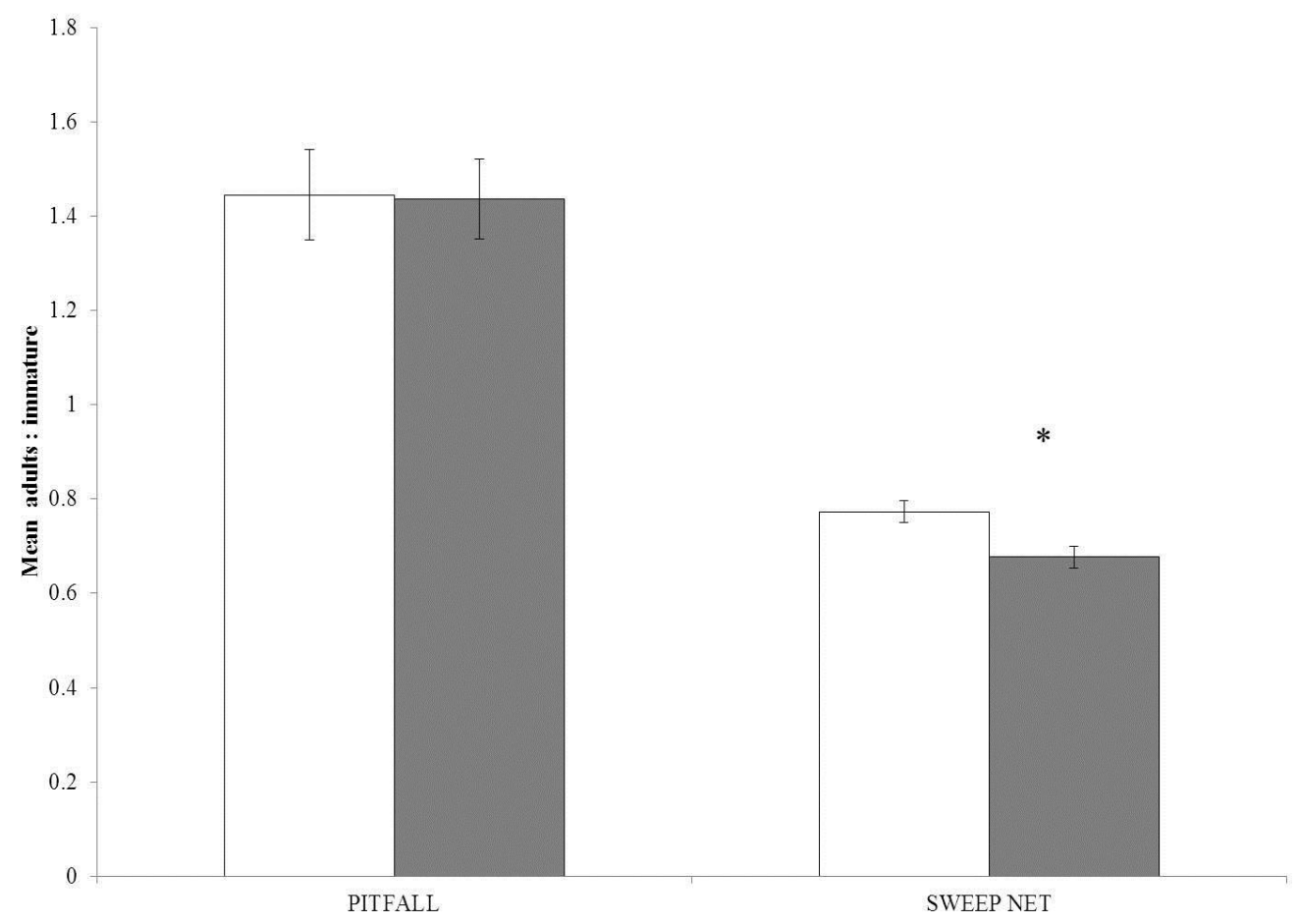

Figure 11. Ratio of adult:immature spiders caught in pitfall traps and sweep nets in invaded (Dark Bars) and uninvaded (Light Bars) sites in 2010-201. * $*$ p $<0.01$ (Bonferonni adjusted significance), Error bars are +/- S.E. 
A

Functional Groups in Sweep Net Samples

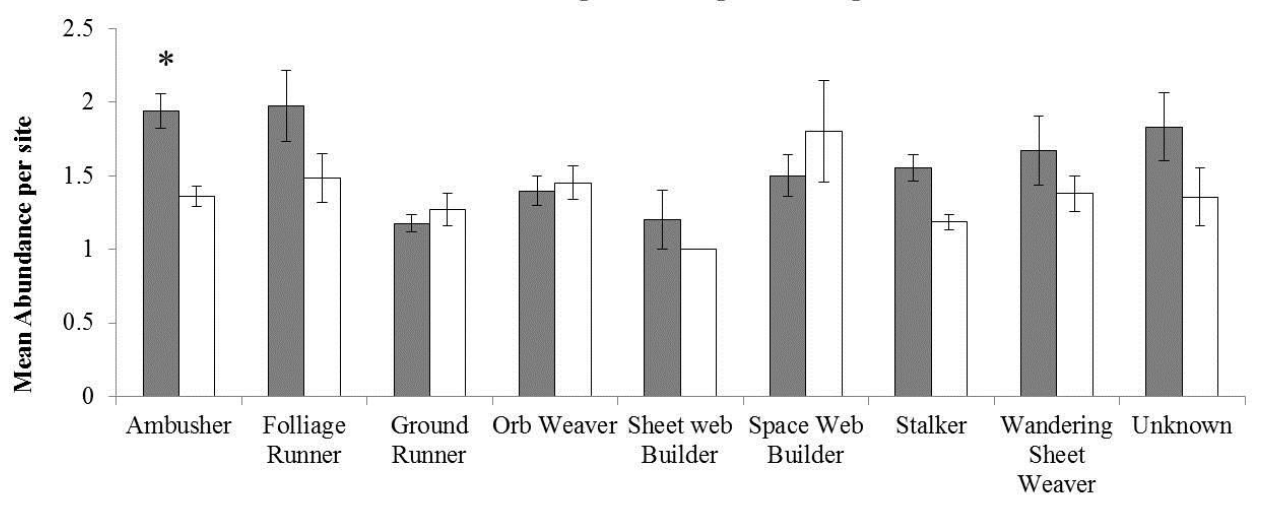

B

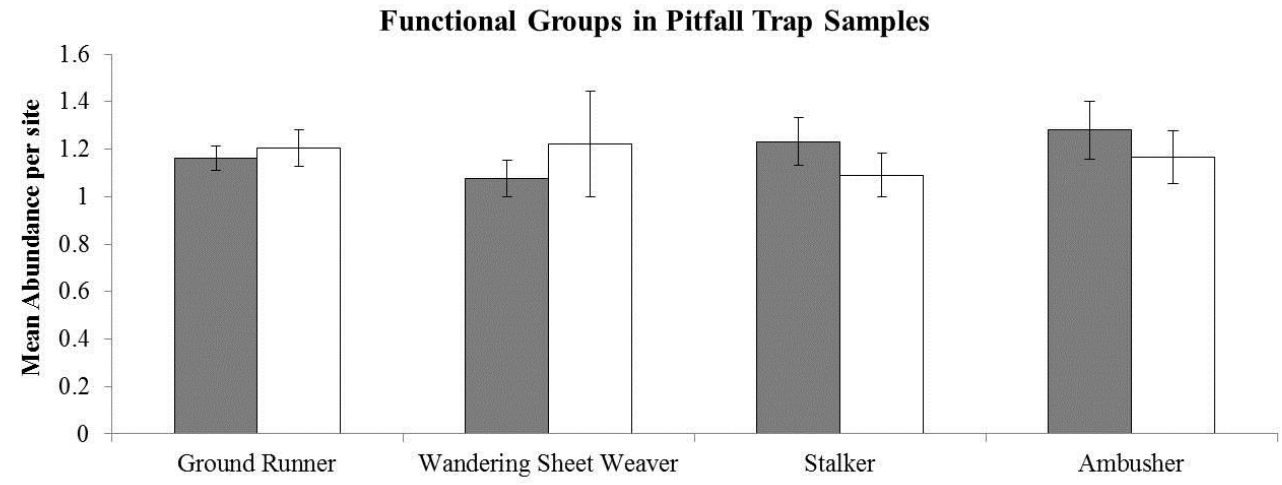

Figure 12. Mean functional guild total abundance for A) Sweep Net and B) Pitfall Trap sampling methods. Dark bars indicate sites invaded by $M$. vimineum while open bars are uninvaded sites. captured from MayOctober 2010,2011. ${ }^{*}=p<0.01$ (Bonferroni adjusted significance), Error bars are +/- S.E. 
A

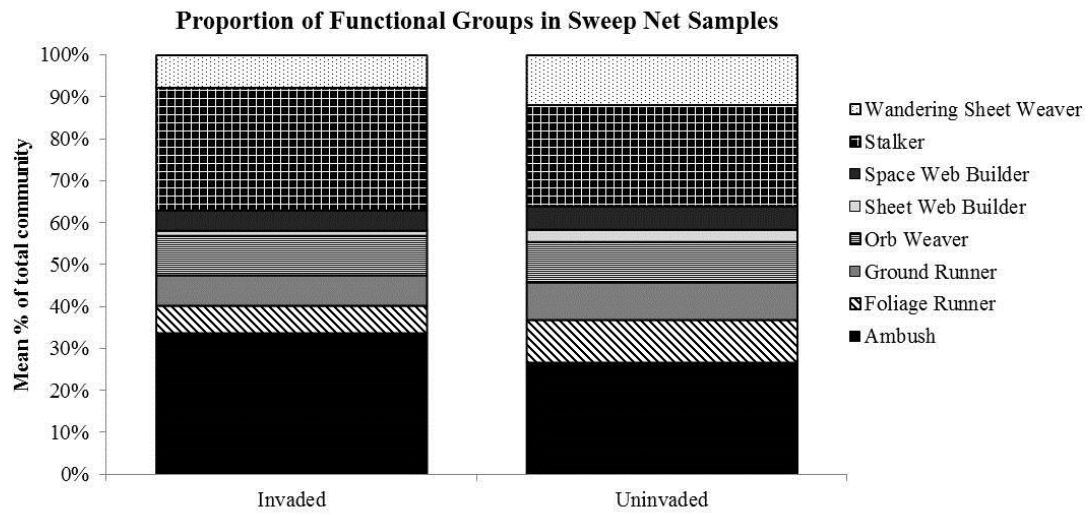

B
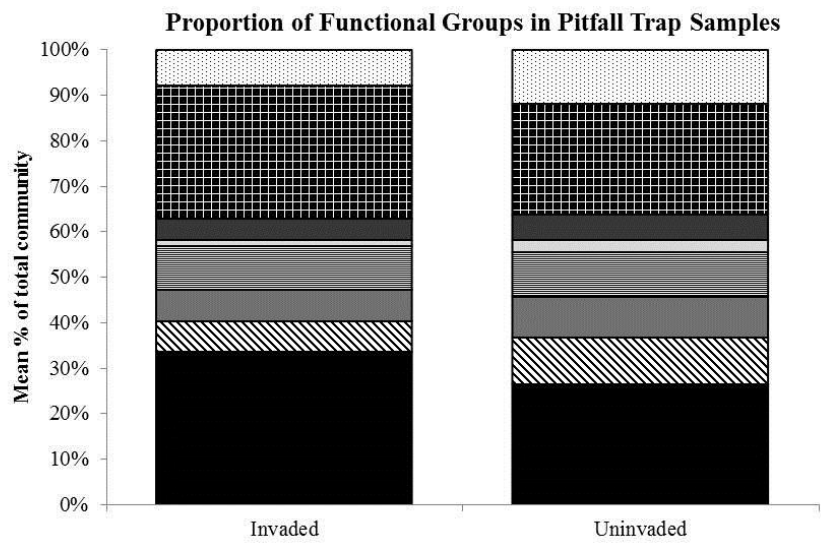

๑Wandering Sheet Weaver

ت Stalker

- Space Web Builder

$\square$ Sheet Web Builder

目Orb Weaver

घGround Runner

QFoliage Runner

-Ambush

Figure 13. . Mean functional guild relative abundance for A) Sweep Net and B) Pitfall trap sampling methods captured from May-October 2010,2011 


\section{CHAPTER 4}

THE INVASIVE PLANT MICROSTEGIUM VIMINEUM ALTERS ARTHROPOD COMMUNITIES THROUGH CHANGES IN VEGETATION STRUCTURE AND DIVERSITY

\section{SUMMARY}

The impact of invasive plants on plant community structure, ecosystem processes and resource availability can have serious implications for the composition and structure of higher trophic levels. Microstegium vimineum is an invasive plant of Eastern deciduous forests that has been shown to alter not only native plant diversity and biomass availability, but also structural complexity in forest understories, both of which can influence arthropod abundance and diversity. In this study I ask whether changes in native plant community composition or increases in structural complexity associated with M. vimineum invasion are driving changes in arthropod community structure in a north central Kentucky disturbed forest. I manipulated the plant community in a field experiment with four treatments: a control; a Microstegium removal $[M v(-)]$; a Microstegium monoculture [Mv mono]; and a Microstegium addition $[M v(+)]$. Results from our study indicated that $M$. vimineum invasion can alter arthropod communities through changes to both structural complexity and native plant diversity. I found significant increases in arthropod abundance, specifically in herbivore and carnivore trophic groups, associated with our $M v(+)$ treatments. Significant decreases in arthropod community abundance, diversity and richness were associated with our Mv mono treatments. These results indicate that carnivores, specifically spiders may be responding more strongly to increases in structural complexity; while herbivores, specifically leaf 
hoppers, may be responding more strongly to changes in biomass availability. While the overall effects of $M$. vimineum invasion appear to be context dependent, it is possible that at moderate levels of invasion, the increased biomass cover and structural complexity can benefit arthropods in the invaded system. 


\section{INTRODUCTION}

While invasion biology is one of the fastest growing fields in ecology, the impacts of invasive species on multiple trophic levels has only recently been evaluated (Bartomeus et al. 2008, Heleno et al. 2008, Marshall and Buckley 2009, Simao et al. 2010). Invasive plants in particular have the ability to seriously impact trophic dynamics within a system as they are known to dramatically alter not only plant community structure, but ecosystem processes and resource availability (Ehrenfeld et al. 2001, Crooks 2002, Ehrenfeld 2003, McGrath and Binkley 2009). While some experimental and theoretical work has examined trophic interactions in the context of invasions and other historical factors (Yodzis 1981a, 1981b, Post and Pimm 1983, Drake 1990, 1991), work on natural communities remains limited (Kitching 1987, Topp et al. 2008, Haddad et al. 2009). While several studies have shown clear impacts of plant invasion on arthropod community structure (Belnap and Phillips 2001, Belnap et al. 2005, Kappes et al. 2007, Topp et al. 2008), the mechanisms causing such impacts remain unclear.

Invasive plants can alter the abundance and diversity of higher trophic levels in a variety of ways. Invasion effects are often seen in the reduction of native plant biomass and loss of plant diversity as invasion density increases (Carvalheiro et al. 2010, Simao et al. 2010). In many cases, invading plant species are not as nutritionally beneficial to herbivores, and this reduced nutritional quality may limit the performance of herbivores, and consequently predators and parasitoids (Winemiller and Polis 1996, Couture et al. 2010). The potential impact of such bottom-up effects on consumers from a reduction in

consumable resources is considered to be much stronger than that of top-down effects of 
predation (Osenburg and Mittlebach 1996). Additionally, plant invasion can result in increases in plant biomass and changes in structural complexity. Increases in plant biomass often result in increased cover and habitat availability for arthropods (Borges and Brown 2001). A meta-analysis, conducted by Langelletto and Denno (2004), found a significant positive effect of plant invasions on the abundance of natural enemies (carnivores) of arthropods in studies that controlled for or manipulated vegetative structural complexity. Increases in vegetation structural complexity could lead to a variety of trophic level impacts including reducing encounter rates between prey and predators by limiting predators ability to detect prey (Janssen et al. 2007), or increasing predation rates by providing increased niche availability for predators. For example, Pearson (2010) found that indirect effects of Centaurea maculosa invasion on arthropod prey resulted from the increased number of attachment points available to web building spiders. Further, changes in structural complexity have been associated with significant reductions in intra-guild predation and cannibalism, limiting the effects of multiple predators on each other and increasing their combined effect on herbivore prey in the system (Crooks 2002, Finke and Denno 2002, Langellotto and Denno 2004, Janssen et al. 2007, DeVore 2011). Teasing apart these multiple effects of invasive plants on other trophic levels becomes important when trying to predict and manage ecosystem effects of invasion.

In this study I ask whether manipulated changes in native plant community structure or increases in structural complexity are driving changes in arthropod community structure associated with invasion of Microstegium vimineum (Trin.) A. Camus. Microstegium vimineum is an annual $\mathrm{C}_{4}$ grass that readily invades the understory of temperate deciduous forests in the eastern portion of the U.S., often outcompeting 
native forbs and grasses (Oswalt and Oswalt 2007, Civitello et al. 2008, USDA 2008, Flory and Clay 2009, Adams and Engelhardt 2009, Metcalf 2013a). This invasive plant is associated with increased vegetation biomass as well as increased structural complexity, and is reported to be unpalatable to native arthropod herbivores, further increasing its competitive advantage over native plant species (Flory and Clay 2009, 2010a, 2010b, Adams and Engelhardt 2009, Strickland et al. 2010, DeVore 2011, Metcalf 2013a).

The effects of $M$. vimineum on arthropod communities appear to be context dependent, with studies showing that this invasive grass can increase, decrease or have no effect on insect and spider communities (Civitello et al. 2008, Marshall and Buckley 2009, Simao et al. 2010, Tang et al. 2012, Metcalf 2013a, 2013b). Our own work has previously demonstrated a clear increase in arthropod abundance and diversity, with significant increases in both carnivore and herbivore functional guilds in areas invaded by M. vimineum (Metcalf 2013a, 2013b). Given these findings, I conducted a manipulative experiment designed to examine potential mechanisms by which $M$. vimineum invasion could alter arthropod abundance. In this study, I ask the following questions: 1) Are reductions in native plant abundance in habitats invaded by $M$. vimineum associated with reductions in arthropod abundance and diversity? 2) Are increases in vegetation structural complexity or biomass in habitat invaded by $M$. vimineum associated with increases in arthropod abundance and diversity? And 3) Does the strength of these different effects depend on arthropod functional guild identity? 


\section{METHODS}

\section{Experimental Design}

This study was conducted at the University of Louisville Horner Wildlife Research Forest in Brownsboro, Kentucky (38:20:27 N, 85:31:53.7 W). This is an 81 ha highly disturbed second-growth temperate deciduous forest in Northern Kentucky, with an upland area devoid of any natural permanent water source, and a lowland area bordering a stream.

In March 2012, forty $2 \mathrm{~m}$ x 2m plots arranged in a 4 x 10 grid were established in a large area of understory with a relatively low-density M. vimineum invasion ( $27 \%$ cover $)$ and an intact native plant community $\left(\sim 9\right.$ species $\left./ \mathrm{m}^{2}\right)$. The plots comprised 10 replicates of each of four treatments: a control; a Microstegium removal $[\mathrm{Mv}(-)]$; a Microstegium monoculture [Mv mono]; and a Microstegium addition $[M v(+)]$ (Table 8). The Mv mono treatment tested whether loss of native plants was the primary mechanism by which $M$. vimineum altered arthropod abundance and diversity. The $M v(-)$ and $M v(+)$ treatments alternatively tested whether changes in plant community biomass and structure were responsible for arthropod community changes. Plant communities were left undisturbed in the control sites. In the $M v(-)$ treatment, all $M$. vimineum plants were removed by hand approximately two weeks prior to initial sampling by either pulling by the root if possible without significant soil disturbance, or clipping at ground level. Additional treatment maintenance was conducted approximately 1 week prior to each monthly sampling event over the course of the summer. In the $M v$ mono treatment, all herbaceous plants except $M$. vimineum were removed from plots in a similar manner to the $M v(-)$ treatment, and treatments similarly maintained monthly throughout the summer. For the $M v(+)$ treatment approximately 500 additional $M$. vimineum seeds were 
added to each of the 10 replicate plots approximately 2 months prior to initial arthropod sampling. Stem counts indicated that I effectively doubled the invasion density with this seed addition.

\section{Vegetation sampling}

To evaluate the effectiveness of our treatments, plant community data were collected each month from May-October 2012 by visually estimating the percent cover of each of four plant morpho-types: M. vimineum, forbs, non-Microstegium grasses, and sedges. Because destructive sampling to estimate biomass cover was not possible due to plot size, percent bare ground in each plot was visually estimated as a surrogate for biomass cover. Vegetation structural complexity was estimated by placing a standard meter stick perpendicular to the ground at 5 points in each treatment (one in each corner and one in the center) and taking the mean of the number of contact points between the plants and the meter stick at each point. These measurements were averaged to create an overall estimate of plant architecture per plot.

\section{Arthropod sampling}

Arthropod community samples were collected once per month, from MayOctober 2012 using pitfall traps and sweep nets. These two sampling methods allow for a more complete survey of the arthropod community as they target different functional groups in the system. Two pitfall traps were placed in the center $1 \mathrm{~m}^{2}$ of each plot approximately 2 weeks prior to the initial sampling event. Traps were made using 10.16 $\mathrm{cm}$ diameter PVC pipe cut to $10.16 \mathrm{~cm}$ long and placed flush into pre-dug holes in the soil. Traps were set by placing empty $0.24 \mathrm{~L}$ plastic cups into the PVC. After 48 hours, the cups were removed from the PVC and samples were pooled for each plot and emptied into zip-top bags for transport back to the lab. Two sweep net samples (4-sweeps per 
sample) were collected from the interior $1 \mathrm{~m}^{2}$ of each plot, with 30 minutes between samples to allow for community recovery after disturbance. Sweep net samples were pooled for each plot, transferred to zip-top bags and returned to the lab. Samples were stored at $-10{ }^{\circ} \mathrm{C}$ until processing.

Individual arthropods were identified to family and morpho-group using Johnson and Triplehorn (2005). Families were assigned to a trophic group (carnivore, herbivore, and detritivore), functional guild, and morpho-group (Table 3) using typical feeding information found in Marshall (2009) and Gratton \& Denno (2005). Some families were best classified as omnivores; however these were not common and were therefore eliminated from guild analysis. Shannon diversity and evenness indices for pitfall and sweep net traps (Shannon 1948) were calculated using arthropod family abundance values.

\section{Data Analysis}

I conducted an ANOVA using treatment as a fixed factor and season as a covariate to account for known variation in arthropod communities on plant and arthropod data from the 40 sites to compare the effects of plant community manipulations on arthropod abundance and diversity. Sampling months were combined to roughly approximate season: Spring (May-June); Summer (July-August); and Fall (SeptemberOctober). Tukey's HSD post-hoc test was then used to conduct pairwise comparisons between each of the treatments on significant ANOVA results. The community composition and functional groups that are typically collected using pitfall traps and sweep nets are different from one another. Therefore arthropods collected by each of these trap types were analysed separately. Analyses were completed for overall abundance and diversity at the family level for each trap type. Further trophic group 
analyses were done only when overall arthropod abundance significantly differed among treatments; follow-up functional guild analyses were done for those trophic groups that showed significant differences among treatments; and follow-up morpho-type analyses were done within the functional guilds that showed significant differences among treatments. Simple Pearson correlations were used to evaluate the relationship between responsive functional guilds, the plant architecture and percent bare ground. To avoid problems with multiple comparisons with each model, I used Bonferroni corrected pvalues based on the number of comparisons within each analysis. All analyses were done using Systat v. 13(2009).

\section{RESULTS}

\section{Vegetation}

The treatments effectively altered plant community diversity, physical structure and cover. While the control sites showed both non-M. vimineum grasses and $M$. vimineum as co-dominant, with forbs the third most dominant plant type, I saw a shift to forbs as the dominant plant group in the $M v(-)$ plots and $M$. vimineum as the sole dominant in the $M v(+)$ and $M v$ mono plots (Table 9A, Fig. 14A). As compared to controls, percent cover of forbs was significantly higher in the $M v(-)$ plots (by 65\%) and significantly lower in the $M v$ mono plots (by 99\%). Percent cover of non- $M$. vimineum grasses in the $M v(+$ ) plots were significantly lower (by 69\%) and as compared to other treatments.

Plant architecture was significantly different in all treatments, with the $M v(+)$ plots having the highest values and the Mv mono having the lowest (Table 9B, Fig. 14B). Mean contacts in the $M v(+)$ plots were higher (by 15\%) and $M v$ mono plots were lower (by 51\%) than the control (Fig. 14B). Percent bare ground was used to estimate biomass cover by difference, and compared to controls was significantly reduced in the $M v(+)$ 
plots(by 45\%, indicating higher biomass cover), but increased dramatically in the $M v$ mono plots (by 128\%, indicating reduced biomass cover) over the seasons (Fig. 14C). Arthropod Abundance and Diversity

Over the course of the 2012 field season, 3618 total arthropods comprising 80 families were collected using pitfall traps and sweep nets. Abundance of arthropods captured by sweep net was highest in the $M v(+)$ plots and lowest in the $M v$ mono plots (Table 10A, Fig. 15A). The $M v(+)$ treatments had significantly higher arthropod abundances (by 35\%), and the Mv mono plots were significantly lower (by 49\%) than controls. The $M v(-)$ treatments did not show any statistical difference from the control. Because there were no significant differences in the abundance of arthropods captured by pitfall traps for any of the treatments (Table 10A, Fig. 15A), these data were eliminated from further analysis.

Shannon diversity differed in the sites dominated by $M$. vimineum with $M v(+)$ treatments resulting in increased arthropod diversity, and $M v$ mono treatments resulting in a decreased arthropod diversity as compared to other treatments (Table 10B, Fig. 15B). Post hoc analysis showed that the $M v(+)$ treatment had a significantly higher diversity index (by 32-136\%) than the $M v(-)$ and $M v$ mono treatments, but did not differ from the control. Mv mono plots had a significantly lower diversity index (by 13-24\%) than the control and the $M v(-)$ treatments (Fig. 15B). Family richness showed a similar pattern to diversity, with $M v(+)$ resulting in an overall increase in richness and $M v$ mono resulting in an overall decrease as compared to other treatments (Table 10B, Fig. 15C). Arthropod richness was highest in the $M v(+)$ plots (by 46-161\%) as compared to other treatments, but did not differ from the control. The lowest richness was in the Mv mono 
treatment (by 44-6172\%) as compared to other treatments (Fig. 15C). Shannon evenness (Eh) did not differ between treatments.

While I did see seasonal differences as well as season-by-treatment interactions in overall abundance and diversity indices (Table 10A, B), these types of variation are common in arthropod communities (Denlinger 1980, Lowman 1982) and are not further discussed here.

\section{Arthropod Trophic Groups and Functional Guild Structure}

Trophic group analysis showed significant differences in two of the three groups analyzed (Table 10C). Carnivore and herbivore abundance showed similar patterns (Fig. 15D), with the highest increases in abundance in the $M v(+)$ treatment (35-58\% greater than control) and lowest in the Mv mono treatment (56-59\% less than control). There were no significant differences between the control and the $M v(-)$ treatments for either of these trophic groups.

Further functional guild analyses were conducted for all trophic groups except detritivores, which did not differ among treatments (Table 10C). Within the carnivore trophic group, only the predators showed significant differences among treatments after Bonferroni corrections (Table 11A). Predator abundance was highest in the $M v(+)$ treatments and lowest in the $M v$ mono treatments. Predator abundance values in the $M v(+)$ treatment increased by $64 \%$, while abundance values in the $M v$ mono treatment decreased by $56 \%$, when compared to the control (Fig. 16A). Significantly responsive taxa in the predator functional guild included Formicidae (ants), Reduviidae (assassin bugs), and spiders (Table 11B). Of these, spiders abundance exhibited the most significant increase in the $M v(+)$ treatments $(73 \%$ greater than control) and the most significant decrease in the Mv mono treatments (63\% less than control) (Fig. 16B). 
Within the herbivore trophic group, only the free-living sap feeders showed significant differences between treatments after Bonferroni correction (Table 11C). Free living sap feeder abundance followed the same overall pattern as the predators, with the highest abundance in the $M v(+)$ treatment and the lowest in the $M v$ mono. Free-living sap feeder abundance in the $M v(+)$ treatment was higher (by 49\%), while abundance values in the Mv mono treatment decreased (by 65\%), when compared to controls (Fig. 16C). Significantly responsive taxa in this functional guild were the Cicadellidae (leaf hoppers), Delphacidae (plant hoppers) and Cercopidae (spittle bugs). Of these, Cicadellidae (leaf hopper) abundance exhibited the most significant increase in $M v(+)$ treatments (68\% greater than control) and the most significant decrease in Mv mono (71\% less than control) (Fig. 16D).

Simple correlation analyses showed a difference in the relationships between responsive functional guilds and plant structure and biomass surrogate variables. Carnivore (predator) abundance was significantly correlated positively to plant architecture $(\mathrm{r}=0.436, \mathrm{p}=<0.001)$ and negatively to percent bare ground $(\mathrm{r}=-0.437$, $\mathrm{p}<0.001$ ). Herbivore (free-living sap feeder) abundance was also significantly correlated with these vegetation variables, but the relationship was weaker for plant architecture $(\mathrm{r}=0.312, \mathrm{p}=<0.001)$ than it was for percent bare ground $(\mathrm{r}=-0.451, \mathrm{p}<0.001)$.

\section{DISCUSSION}

Results from our study indicate that $M$. vimineum invasion can alter arthropod communities through changes to both architecture and native plant diversity. Arthropods collected via sweep net indicate community diversity and abundance responds dramatically and differently to the treatments applied to plant communities. However, arthropods in the pitfall traps showed little response to any of the plant community 
treatments in this study. Below, I discuss the multiple ways that $M$. vimineum invasion may alter arthropod communities.

\section{Are reductions in native plant abundance in habitat invaded by M. vimineum associated with reductions in arthropod abundance and diversity?}

Removal of native plant abundance ( $M v$ mono treatments) resulted in a significant decrease in structural complexity and a decrease in biomass cover. Removing native plants had the largest effect on arthropod diversity, reducing arthropod family richness and diversity by half compared to control plots. These data support other research showing that decreases in native plant diversity can reduce arthropod abundance and species richness through a variety of mechanisms (Haddad et al. 2009). The decrease in arthropod abundance, richness, and diversity associated with $M$. vimineum monoculture plots could be related to a loss of preferred food resources. While there is evidence that certain arthropod groups (specifically free-living sap feeders) may use $M$. vimineum as a food source (Bradford et al. 2009), the predicted lower nutritional quality due to increased levels of silica and fiber compared to native vegetation (Caswell et al. 1973, Barbehenn 2005, Cebrian et al. 2009), and the availability of native food resources in neighboring treatments may have resulted in herbivores seeking better quality food resources elsewhere. Time since invasion could have significant impacts on the use of $M$. vimineum as a food resource as herbivore damage on non-native plants is dependent on herbivores that are able to recognize and utilize this novel resource (Carpenter and Cappuccino 2005). As this is a relatively small invasion in this experimental location, and native plant resources are still plentiful, it is likely that the creation of monoculture stands of $M$. vimineum resulted in a significant decrease in arthropod abundance and diversity due to food limitation. 
However, food limitation is not the only mechanism that could be operating in this system. Removal of all non-M.vimineum herbaceous plants also resulted in a significant decrease in structural complexity and biomass cover. Because the invasion density in this forest is relatively low, several of the plots assigned to this treatment were left relatively bare (32-91\% bare ground), resulting in a decrease of habitat and niche availability for arthropods. Reduction in plant productivity is expected to result in a decline in abundance and biomass of primary consumers (Tallamy 2004, Carpenter and Cappuccino 2005). For example, Wimp et al, (2010) evaluated trophic level impacts of plant biomass on arthropod species richness and found a positive linear relationship. Increased primary productivity provides necessary habitat to support higher abundances of herbivores, leading to increases in herbivore species richness. Without studies explicitly examining herbivore food preferences in this system, it is impossible to clearly separate these two mechanisms.

\section{Are increases in physical structure or biomass in habitat invaded by M. vimineum} associated with increases in arthropod abundance and diversity?

Of the three experimental treatments, the $M$. vimineum seed addition $M v(+)$, which effectively doubled the density of the invader, showed the largest increase in overall arthropod abundance over the control sites. However, M. vimineum seed addition had no effect on arthropod diversity or family richness. While the level of invasion in the $M$. vimineum addition plot did reduce the occurrence of forbs in these treatments, I did not achieve an invasion density that completely eliminated all native food sources while still providing increased structural complexity and biomass cover. This treatment instead showed that native plant presence alone does not solely structure arthropod communities. Instead, as long as some native plants are still in the ecosystem, dense invasions of $M$. 
vimineum may actually increase arthropod abundance. It is most likely that the increases in arthropod abundance associated with denser invasions of $M$. vimineum are due to increases in vegetation structural complexity. Predators, in particular, have been shown to respond positively to such increases in structural complexity, due to increases in niche diversity and reduction of intra-guild predation (Finke and Denno 2002, 2006, Langellotto and Denno 2004, 2006). However, the expected response of herbivores to increased structural complexity is less clear. Langellotto and Denno (2004) found no effect of increased structural complexity on herbivore populations, while other researchers found that herbivorous prey (specifically leaf hoppers) should have reduced abundance in more structurally complex habitats (Finke and Denno 2006, Janssen et al. 2007). The increase I found in herbivores, specifically leaf hoppers, could result from a differential response to the increased structural complexity by intra-guild predators (spiders) and herbivorous prey that may have influenced encounter rates, and impacted predation rates through reduced capture success (Finke and Denno 2006). Another potential explanation for the increased herbivore abundance in this treatment is the continued presence of native food sources along with the additional biomass cover. More detailed work is needed to assess the long-term effects of increased structural complexity associated with changes in higher trophic level responses

\section{Does the strength of these different effects depend on arthropod functional guild}

\section{identity?}

I demonstrate increased insect and spider abundances, as well as increases at both the carnivore and herbivore trophic levels associated with M. vimineum invasion in this system (Metcalf 2013a, 2013b). This study provides additional support not only for increased arthropod abundance and diversity in M. vimineum invaded sites, but also 
provides support for the idea that increased biomass and increased structural complexity that results from this invasive grass are driving the current increases of carnivores and herbivores in this system.

Changes in both arthropod diversity and abundance were mostly driven by responses of spiders and leaf hoppers. The M. vimineum monoculture treatment ( $M v$ mono) resulted in a significant decrease in overall abundance, diversity, and family richness when compared to the control. This difference was seen in carnivore and herbivore trophic levels, with assassin bugs and spiders (carnivore -- predator), and leaf hoppers and plant hoppers (herbivore -- free-living sap feeder) showing the most significant differences from the control sites.

Because of the different roles these groups play in food webs, I expected that carnivores would respond to increases in plant architecture, while herbivores would be more sensitive to changes in plant biomass (Tallamy 2004, Denno et al. 2004, Carpenter and Cappuccino 2005, Finke and Denno 2006, DeVore 2011). The differential response I demonstrated through the correlational analyses indicate a stronger response of carnivores (spiders) to plant architecture, and a stronger response of herbivores (leaf hoppers) to biomass cover. While these differences were minor, it is possible that as invasion density increases, these differences could be magnified. This response is likely context dependent, and as invasions increase in extent and age, the role of increasingly scarce native plants may override the benefits of increased habitat and cover provided by

\section{M. vimineum.}

While the overall effects of $M$. vimineum invasion appear to be context dependent, there is significant evidence that at moderate levels of invasion, the increased biomass cover and structural complexity can lead to increased abundance and diversity of 
arthropods in the invaded system. Complete removal of $M$. vimineum is not realistic, however land management officials and decision makers should seriously consider mechanisms by which native plant diversity can be maintained in spite of the presence of this invader, thus limiting its negative impacts and potentially increasing the arthropod diversity in the system. 
Table 8: Description and mechanisms tested for each treatment

\begin{tabular}{|l|l|l|}
\hline \multicolumn{1}{|c|}{ Treatment } & \multicolumn{1}{|c|}{ Description } & \multicolumn{1}{c|}{ Mechanism tested } \\
\hline Control & Native plant community & Baseline community for comparison \\
\hline$M v(-)$ & M. vimineum removal & $\begin{array}{l}\text { Effect of plant community biomass and structure } \\
\text { reduction on arthropod communities }\end{array}$ \\
\hline Mv mono & M. vimineum monoculture & $\begin{array}{l}\text { Effect of loss of native plant resources on arthropod } \\
\text { communities }\end{array}$ \\
\hline$M v(+)$ & M. vimineum addition $(+500$ seeds $)$ & $\begin{array}{l}\text { Effect of plant community biomass and structure } \\
\text { increase on arthropod communities }\end{array}$ \\
\hline
\end{tabular}

Table 9: Results from ANOVAs for A) \% cover of forbs, grasses, M. vimineum and sedges and B) plant architecture and \% bare ground. Significant p-values are shown in bold.

\begin{tabular}{|c|c|c|c|c|c|c|c|c|}
\hline \multirow{2}{*}{ A } & \multicolumn{2}{|c|}{ Forb } & \multicolumn{2}{|c|}{ Grass } & \multicolumn{2}{|c|}{ M. vimineum } & \multicolumn{2}{|c|}{ Sedge } \\
\hline & $\mathrm{F}$ & $\mathrm{p}$ & $\mathrm{F}$ & $\mathrm{p}$ & $\mathrm{F}$ & $\mathrm{p}$ & $\mathrm{F}$ & $\mathrm{p}$ \\
\hline Treatment & 112.77 & $<0.001$ & 78.33 & $<0.001$ & 100.39 & $<0.001$ & 67.591 & $<0.001$ \\
\hline Season & 6.26 & 0.002 & 3.133 & 0.045 & 4.75 & 0.010 & 11.301 & $<0.001$ \\
\hline Treat x Season & 0.991 & 0.432 & 0.875 & 0.514 & 0.739 & 0.619 & 3.355 & 0.003 \\
\hline \multirow{2}{*}{ B } & \multicolumn{4}{|c|}{ Plant Architecture } & \multicolumn{4}{|c|}{ Bare ground } \\
\hline & \multicolumn{2}{|c|}{$\mathrm{F}$} & \multicolumn{2}{|c|}{$\mathrm{p}$} & \multicolumn{2}{|c|}{$\mathrm{F}$} & \multicolumn{2}{|c|}{$\mathrm{p}$} \\
\hline Treatment & \multicolumn{2}{|c|}{12.04} & \multicolumn{2}{|c|}{$<0.001$} & \multicolumn{2}{|c|}{90.61} & \multicolumn{2}{|c|}{0.001} \\
\hline Season & \multicolumn{2}{|c|}{8.71} & \multicolumn{2}{|c|}{$<0.001$} & \multicolumn{2}{|c|}{21.863} & \multicolumn{2}{|c|}{$<0.001$} \\
\hline Treat x Season & \multicolumn{2}{|c|}{1.919} & \multicolumn{2}{|c|}{0.079} & \multicolumn{2}{|c|}{0.144} & \multicolumn{2}{|c|}{0.990} \\
\hline
\end{tabular}

Table 10: Results from ANOVAs for A) Sweep net (SN) and Pitfall (PF) trap arthropod abundance, B) Sweep net Shannon diversity (H'), Family Richness (S) and Shannon Evenness (Eh), and C) Sweep net carnivore, Detritivore, herbivore and omnivore abundance. Bonferroni adjusted significant p-values are shown in bold.

\begin{tabular}{||l|c|c|c|c|}
\hline \multirow{2}{*}{ A } & \multicolumn{2}{|c|}{ SN ABUNDANCE } & \multicolumn{2}{c|}{ PF ABUNDANCE } \\
\cline { 2 - 5 } & $\mathrm{F}$ & $\mathrm{p}$ & $\mathrm{F}$ & $\mathrm{p}$ \\
\hline Treatment & $\mathbf{2 6 . 3 3}$ & $\mathbf{< . 0 0 1}$ & 0.95 & 0.418 \\
Season & $\mathbf{3 9 . 0 9}$ & $\mathbf{< . 0 0 1}$ & $\mathbf{3 5 . 5 5}$ & $<\mathbf{0 . 0 0 1}$ \\
Treat x season & 0.98 & 0.441 & 0.32 & 0.924 \\
\hline
\end{tabular}

\begin{tabular}{|l|c|c|c|c|c|c|}
\hline \multirow{2}{*}{ B } & \multicolumn{2}{|c|}{ Shannon Diversity $\left(H^{\prime}\right)$} & \multicolumn{2}{c|}{ Family Richness $(\mathrm{S})$} & \multicolumn{2}{c|}{ Shannon Evenness $($ Eh) } \\
\cline { 2 - 7 } & $\mathrm{F}$ & $\mathrm{p}$ & $\mathrm{F}$ & $\mathrm{p}$ & $\mathrm{F}$ & $\mathrm{p}$ \\
\hline Treatment & $\mathbf{2 9 . 4 2}$ & $\mathbf{< 0 . 0 0 1}$ & $\mathbf{3 5 . 3 5}$ & $<\mathbf{0 . 0 0 1}$ & 1.73 & 0.161 \\
Season & $\mathbf{9 2 . 9 9}$ & $<\mathbf{0 . 0 0 1}$ & $\mathbf{1 3 0 . 8 6}$ & $<\mathbf{0 . 0 0 1}$ & 1.25 & 0.288 \\
Treat x season & $\mathbf{2 . 8 0}$ & $\mathbf{0 . 0 1 2}$ & $\mathbf{4 . 5 1}$ & $<\mathbf{0 . 0 0 1}$ & 1.229 & 0.292 \\
\hline
\end{tabular}

\begin{tabular}{|l|c|c|c|c|c|c|}
\hline \multirow{2}{*}{$\mathrm{C}$} & \multicolumn{2}{|c|}{ Carnivore } & \multicolumn{2}{c|}{ Herbivore } & \multicolumn{2}{c|}{ Detritivore } \\
\cline { 2 - 7 } & $\mathrm{F}$ & $\mathrm{p}$ & $\mathrm{F}$ & $\mathrm{p}$ & $\mathrm{F}$ & $\mathrm{p}$ \\
\hline Treatment & $\mathbf{1 7 . 3 6}$ & $\mathbf{< 0 . 0 0 1}$ & $\mathbf{1 9 . 1 3}$ & $<\mathbf{0 . 0 0 1}$ & 0.997 & 0.395 \\
Season & 0.595 & 0.553 & $\mathbf{7 5 . 4 3}$ & $<\mathbf{0 . 0 0 1}$ & $\mathbf{7 . 2 9 1}$ & $<\mathbf{0 . 0 0 1}$ \\
Treat $x$ season & 1.299 & 0.258 & $\mathbf{2 . 7 6 4}$ & $\mathbf{0 . 0 1 3}$ & 1.535 & 0.168 \\
\hline
\end{tabular}


Table 11: Results from ANOVAs for (A) Sweep net carnivore functional group abundance (B) Sweep net predator morpho-group abundance, (C) Sweep net herbivore functional group abundance, (D) Sweep net free-living sap feeder morpho-group abundance. Bonferroni adjusted significant p-values are shown in bold.

\begin{tabular}{|c|c|c|c|c|c|c|c|c|}
\hline \multirow{2}{*}{ A } & \multicolumn{3}{|c|}{ Parasite } & \multicolumn{2}{|c|}{ Parasitoid } & \multicolumn{3}{|c|}{ Predator } \\
\hline & \multicolumn{3}{|r|}{$\mathrm{p}$} & $\mathrm{F}$ & $\mathrm{p}$ & \multicolumn{2}{|c|}{$\mathrm{F}$} & $\mathrm{p}$ \\
\hline Treatment & 1.297 & \multicolumn{2}{|c|}{0.276} & 3.189 & 0.025 & \multicolumn{2}{|c|}{17.97} & $<0.001$ \\
\hline Season & 10.15 & \multicolumn{2}{|c|}{$<0.001$} & 23.565 & $<0.001$ & \multicolumn{2}{|c|}{0.485} & 0.616 \\
\hline Treat $\mathrm{x}$ season & 1.602 & \multicolumn{2}{|c|}{0.147} & 1.921 & 0.078 & \multicolumn{2}{|c|}{1.147} & 0.336 \\
\hline \multirow{2}{*}{ B } & Ant & \multicolumn{2}{|c|}{ Assassin Bug } & Beetle & Harvestman & \multicolumn{2}{|c|}{ Spider } & Stinkbug \\
\hline & $\mathrm{F}, \mathrm{p}$ & \multicolumn{2}{|c|}{$\mathrm{F}, \mathrm{p}$} & $\mathrm{F}, \mathrm{p}$ & $\mathrm{F}, \mathrm{p}$ & \multicolumn{2}{|c|}{$F, p$} & $\mathrm{~F}, \mathrm{p}$ \\
\hline Treatment & $5.03,0.002$ & \multicolumn{2}{|c|}{$4.83,0.003$} & $1.20,0.312$ & $0.45,0.72$ & \multicolumn{2}{|c|}{$19.17,<0.001$} & $0.83,0.48$ \\
\hline Season & $12.23,<0.001$ & \multicolumn{2}{|c|}{$10.68,<0.001$} & $6.45,0.002$ & $16.27,<0.001$ & \multicolumn{2}{|c|}{$0.63,0.53$} & $0.38,0.69$ \\
\hline Treat $\mathrm{x}$ season & $13.24,0.25$ & \multicolumn{2}{|c|}{$3.83,0.001$} & $1.20,0.31$ & $0.94,0.47$ & \multicolumn{2}{|c|}{$0.43,0.86$} & $0.71,0.64$ \\
\hline \multirow{2}{*}{$\mathrm{C}$} & \multicolumn{3}{|c|}{ Concealed Chewer } & \multicolumn{2}{|c|}{ Free-living Chewer } & \multicolumn{3}{|c|}{ Free-living Sap Feeder } \\
\hline & $\mathrm{F}$ & \multicolumn{2}{|r|}{$\mathrm{p}$} & $\mathrm{F}$ & $\mathrm{p}$ & \multicolumn{2}{|c|}{$\mathrm{F}$} & $\mathrm{p}$ \\
\hline Treatment & 0.667 & \multicolumn{2}{|c|}{0.573} & 3.304 & 0.021 & \multicolumn{2}{|c|}{16.871} & $<0.001$ \\
\hline Season & 2.00 & \multicolumn{2}{|c|}{0.138} & 1.725 & 0.180 & \multicolumn{2}{|c|}{85.73} & $<0.001$ \\
\hline Treat $\mathrm{x}$ season & 0.667 & & .677 & 0.948 & 0.461 & & & $<0.001$ \\
\hline D & Aphid & & Lea & hopper & Plant Hop & per & & tlebug \\
\hline D & $\mathrm{F}$ & $\mathrm{p}$ & $\mathrm{F}$ & $\mathrm{p}$ & $\mathrm{F}$ & $\mathrm{p}$ & $\mathrm{F}$ & $\mathrm{p}$ \\
\hline Treatment & 2.57 & 0.06 & 11.92 & $<0.001$ & 8.951 & $<0.001$ & 4.60 & 0.004 \\
\hline Season & 5.36 & .005 & 51.84 & $<0.001$ & 68.63 & $<0.001$ & 8.09 & $<0.001$ \\
\hline Treat x season & 2.97 & .008 & 4.54 & $<0.001$ & 6.372 & $<0.001$ & 2.73 & 0.014 \\
\hline
\end{tabular}




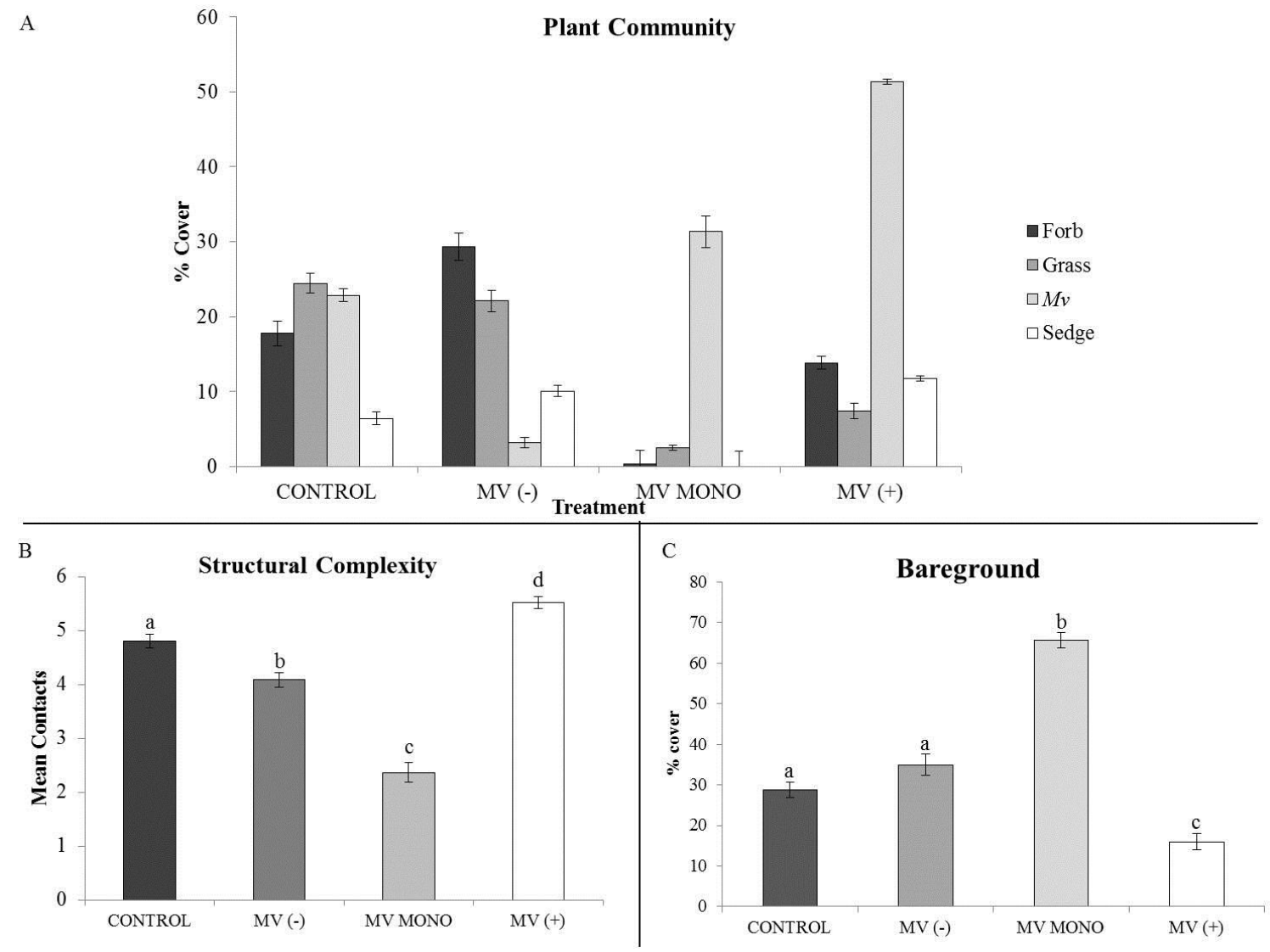

Figure 14. A) Mean \% cover of forbs, non-M. vimineum grasses, $M$. vimineum, and sedges B) Mean plant architecture, and C) Mean \% bare ground for each treatment: Control, $M$. vimineum removal $[\mathrm{Mv}(-)]$, M. vimineum monoculture [ $\mathrm{Mv}$ mono], and $\mathrm{M}$. vimineum addition $[\mathrm{Mv}+)]$ in $2011+/$ - SE. Different letters indicate significant differences of $p<0.05$. Error bars are +/- SE 


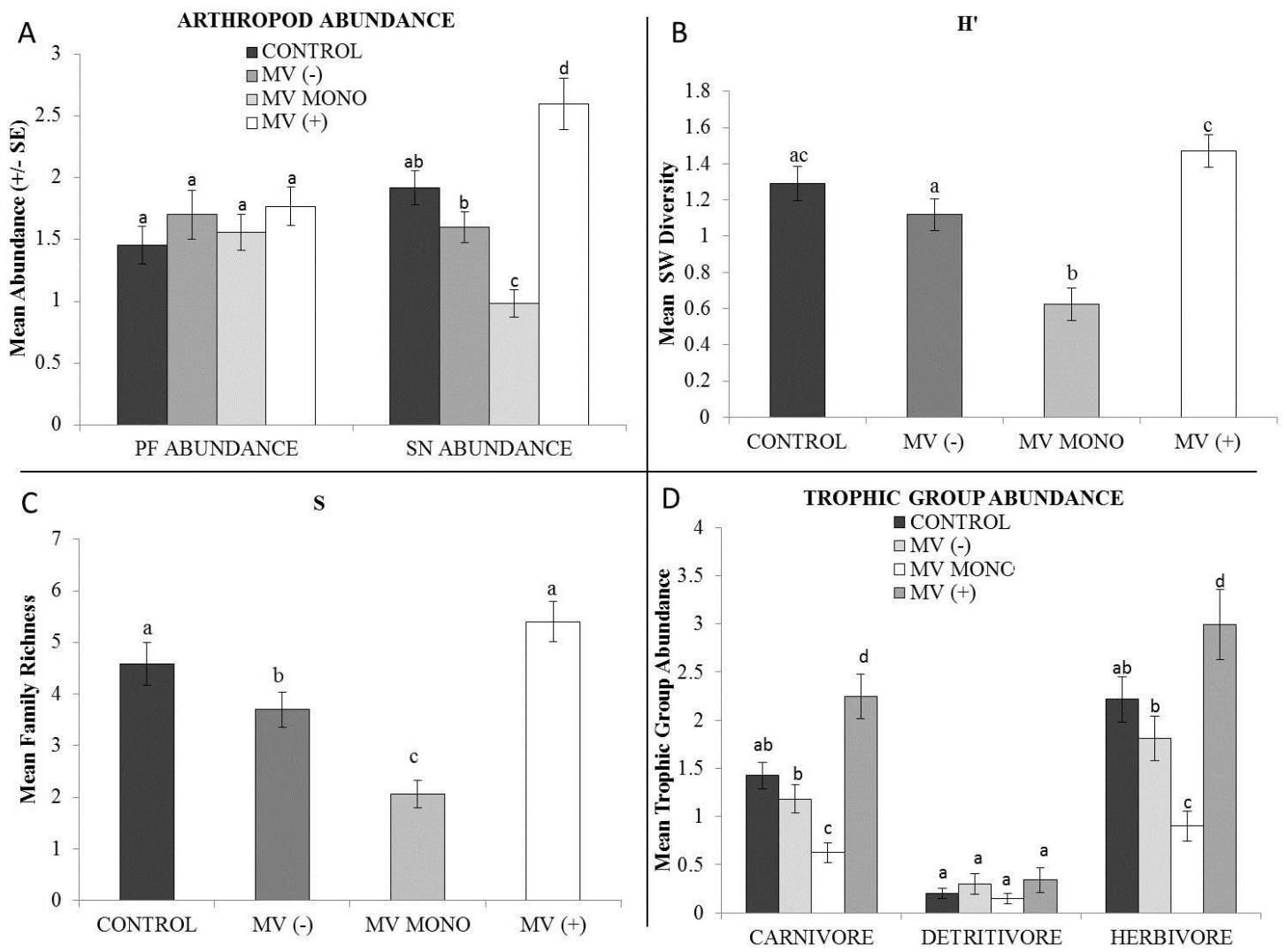

Figure 15. A) Mean arthropod abundance for both pitfall (PF) and sweep net (SN) samples, B)Mean Shannon Diversity for sweep net samples, C) Mean family richness for sweep net samples, and D) mean trophic group abundance for sweep net samples for each treatment: Control, $M$. vimineum removal $[M v(-)]$, M. vimineum monoculture $[M v$ mono $]$, and $M$. vimineum addition $[M v(+)]$ in $2011+/-$ SE. Different letters indicate significant differences of $p<0.05$. Error bars are $+/-\mathrm{SE}$ 


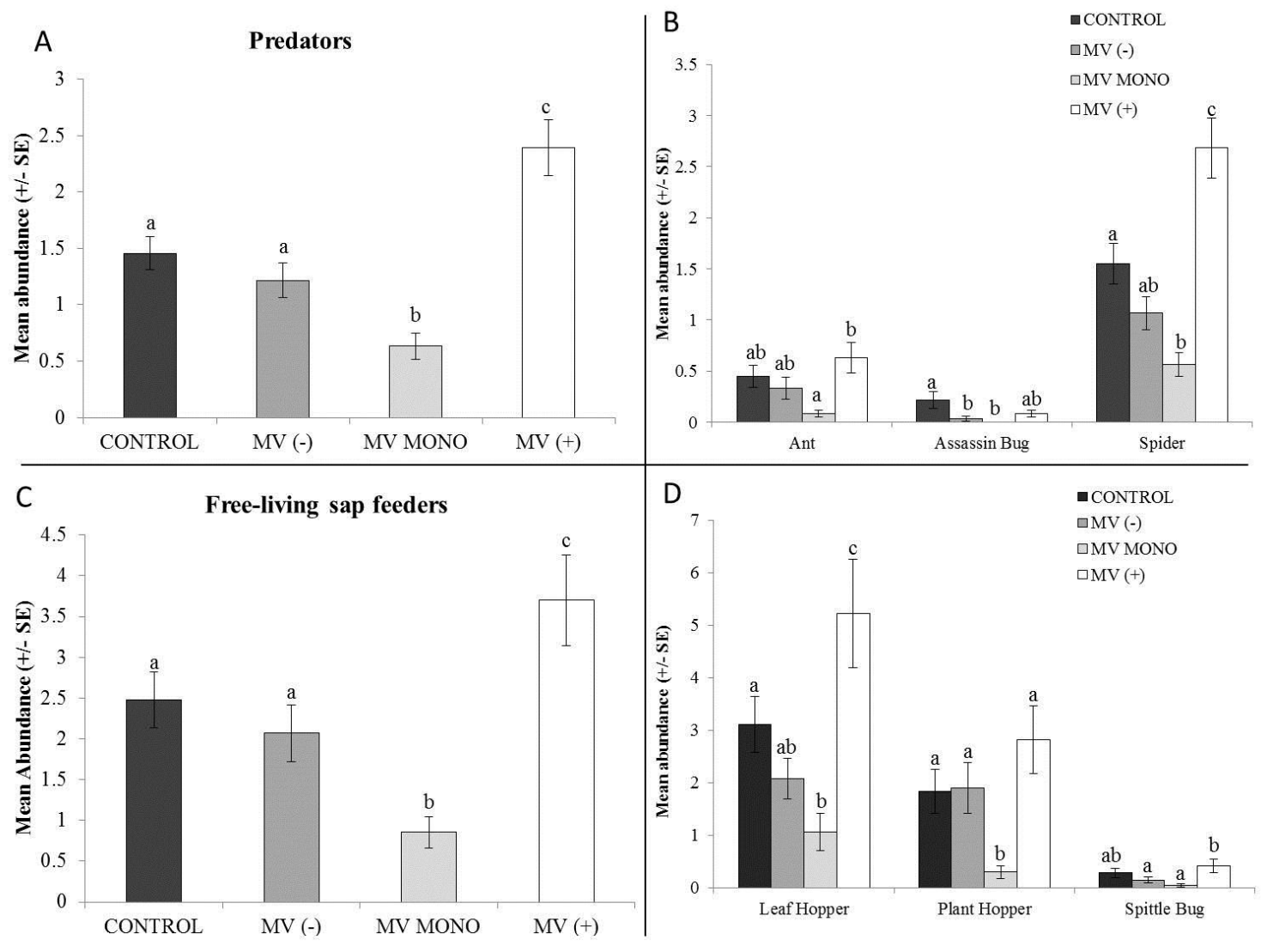

Figure 16. A) mean abundance of the carnivore functional guild: predators from sweep net (SN) samples, B) mean abundance of predator morpho-groups for sweep net samples, $C$ ) mean abundance of the herbivore functional guild: free-living sap feeders, and D) mean abundance of free-living sap feeder morpho-groups for sweep net samples for each treatment: Control, $M$. vimineum removal $[\mathrm{Mv}(-)]$, M. vimineum monoculture $[\mathrm{Mv}$ mono], and $M$. vimineum addition $[M v(+)]$ in $2011+/-$ SE. Different letters indicate significant differences of p<0.05. Error bars are $+/-\mathrm{SE}$ 


\section{CHAPTER 5 \\ SUMMARY AND FUTURE DIRECTIONS}

\section{SUMMARY}

The work presented in this dissertation addressed the associations between invasion of a primary producer and abundance and diversity of higher trophic levels. The survey work presented in chapters two and three show that there is a positive association between invasion and arthropod abundance and diversity at multiple trophic levels. By comparing my findings with similar studies, it appears that this association may be context dependent. The manipulative field experiment discussed in chapter four provides insight into potential mechanisms that may be driving the increased abundance and diversity of arthropods in association with plant invasion. I have shown that increases in structural complexity or biomass availability and decreases in plant community diversity associated with invasion can differentially impact predators and herbivores. While the findings from my research clearly demonstrate relationships (and potential mechanisms) between an invasive plant and increased arthropod community abundance, further research is needed to tease apart specific mechanisms as well as explain conflicting results from similar studies.

\section{FUTURE DIRECTIONS}

My dissertation work addressed the relationship between arthropods and plant invasion from a community perspective. Few studies have addressed the impact of invasion on the arthropod community as a whole, but those that have report conflicting results (Standish 2004, Heleno et al. 2008, Hartley et al. 2010), including studies focusing 
on M. vimineum itself (Civitello et al. 2008, Marshall and Buckley 2009, Simao et al. 2010, Tang et al. 2012). Studies evaluating the mechanisms driving these changes are even less common (Simao et al. 2010). Understanding these mechanisms is vital to improve our ability to manage and control impacts of invasion in temperate forest systems, as well as to explain conflicting results in studies on M. vimineum to date. I see two important future directions for my research to take in order to address these issues.

\section{Better understanding of the differential effects of plant biomass and structure}

Future work in this system would start with additional seasons utilizing the basic design presented in chapter four, with a few additions. I lacked the ability to destructively sample biomass in our treatments due to plot size, and therefore had to use a proxy that was auto-correlated with structural complexity. The addition of biomass plots adjacent to the data collection plots would allow for a stronger evaluation of biomass cover for each treatment. Establishing four biomass plots, one for each treatment, and sampling 1/3 of each plot each season (June/August/October) would provide an overall estimate of biomass for each treatment over the growing season.

I was unable to effectively separate vegetation structure from biomass using the existing design. The addition of a treatment that combines a $M$. vimineum monoculture with the seed addition would provide an opportunity to evaluate the effect of $M$. vimineum biomass on arthropod communities, without the influence of the native food resource. A second additional treatment would include the replacement of all living plant material with non-living (plastic or silk) plants that would provide structural complexity and cover, but would not provide any food resource. I would also like to include a treatment that provides structure, but not biomass cover, potentially using wood, wire or plastic structures without "leaves". In order to accomplish the final treatment, I would 
recommend a methods study comparing wire, wood and plastic structures. This comparative study would allow me to evaluate the effectiveness of each of the three materials to determine if there preference or avoidance of any of the three before establishing the treatment in the field.

2. Evaluating the role of invasion density and size in explaining conflicting findings

The question of changes in invasion density differentially affecting arthropod communities is another that I would like to address in the future. I effectively doubled the density of the existing invasion in manipulative experiment $(\operatorname{Micvim}(+))$, yet still found increased arthropod abundance and diversity. However, the M. vimineum densities at Horner (5-70\% are substantially lower than at other regional sites, possibly indicating that the Horner invasions are relatively new. Invasion densities in systems where other studies evaluating effects of $M$. vimineum on arthropods were conducted were significantly higher, ranging from 80-100\% cover in some sites (Flory 2010, DeVore 2011). I would propose an experiment that would systematically increase invasion density by seed addition, to evaluate whether there is a threshold level of invasion that becomes detrimental to both the plant and arthropod communities in the Horner system. As elimination of $M$. vimineum is not likely, this study would aid managers in planning to control and limit the spread of this invasive plant.

Finally, the question of invasion extent is another that needs to be addressed. The study sites at Horner consisted of fairly small patches of $M$. vimineum $(<0.01$ ha), while studies in other habitats invaded by $M$. vimineum found invasions of several hectares in size (Jayna DeVore, personal communication, September 9, 2013). Arthropods may be able to freely move between small patches of $M$. vimineum and neighboring uninvaded 
habitat at Horner, allowing them to benefit from the extra cover provided by M. vimineum but also access needed native food supplies. As the invasion extent increases, arthropod movement between invaded and uninvaded patches may become limiting, resulting in a negative impact of invasion on arthropod abundances. Such differences in invasion extent may help explain the conflicting findings between my study and those conducted in larger-scale invasions (Civitello et al. 2008, Simao et al. 2010). In order to test this, I would conduct an experiment manipulating the size of invaded and uninvaded plots via removal of M. vimineum. The pilot study for this work would take place at the University of Louisville Horner Wildlife Research Forest in Brownsboro, KY, and survey arthropods associated with natural patches of $M$. vimineum of varying size within this forest. A larger follow-up study would take place in either Bernheim Forest (Kentucky) or Big Oak National Wildlife Forest (Indiana) where the invasion patch sizes exceed 1 ha. Invaded plots of varying sizes would be surrounded by areas of similar size in which M. vimineum would be removed. The use of a grass-specific post emergent herbicide would be utilized within a large invasion patch to create these uninvaded areas. This method of removal was shown to result in the greatest native plant biomass and species richness following removal (Flory and Clay 2009). Arthropods would be collected using sweep nets and pitfall traps. Analysis at the family, trophic and functional guild levels would improve our understanding of the impacts of $M$. vimineum patch size on arthropod community structure. Measures of biomass, plant diversity, and stem counts will be collected and used as covariates in the analysis. This portion of the study will allow me to evaluate how patch size influences the impacts of M. vimineum invasion on arthropod food webs. 


\section{REFERENCES}

Adams, S. N., and K. Engelhardt. 2009. Diversity declines in Microstegium vimineum (Japanese stiltgrass) patches. Biological Conservation 142:1003-1010.

Barbehenn, R. V. 2005. Grasshoppers efficiently process C4 grass leaf tissues: implications for patterns of host-plant utilization. Entomologia Experimentalis et Applicata 116:209-217.

Barden, L. S. 1987. Invasion of Microstegium vimineum (Poaceae), an exotic, annual, shade-tolerant, C4 grass, into a North Carolina floodplain. American Midland Naturalist 118:40-45.

Bartomeus, I., M. Vila, and L. Santamaria. 2008. Contrasting effects of invasive plants in plant-pollinator networks. Oecologia 155:761-770.

Belnap, J., and S. L. Phillips. 2001. Soil biota in an ungrazed grassland: Response to annual grass (Bromus tectorum) invasion. Ecological Applications 11:1261-1275.

Belnap, J., S. L. Phillips, S. K. Sherrod, and A. Moldenken. 2005. Soil biota can change after exotic plant invasion: does this affect ecosystem processes? Ecology 86:30073017.

Borges, P. A., and V. K. Brown. 2001. Phytophagous insects and web-building spiders in relation to pasture vegetation complexity. Ecography 24:68-82.

Bradford, M. A., J. L. DeVore, J. C. Maerz, J. V. McHugh, C. L. Smith, and M. S. Strickland. 2009. Native, insect herbivore communities derive a significant proportion of their carbon from a widespread invader of forest understories. Biological Invasions 12:721-724.

Bultman, T. L., and D. J. DeWitt. 2008. Effect of an invasive ground cover plant on the abundance and diversity of a forest floor spider assemblage. Biological Invasions 10:749-756.

Bultman, T. L., G. W. Uetz, and A. R. Brady. 1982. A comparison of cursorial spider communities along a successional gradient. Journal of Arachnology 10:23-33.

Carpenter, D., and N. Cappuccino. 2005. Herbivory, time since introduction and the invasiveness of exotic plants. Journal of Ecology 93:315-321.

Carpenter, S. R., J. F. Kitchell, and J. R. Hodgson. 1985. Cascading trophic interactions and lake productivity. Bioscience 35:634-639. 
Carvalheiro, L. G., Y. M. Buckley, and J. Memmott. 2010. Diet breadth influences how the impact of invasive plants is propagated through food webs 91:1063-1074.

Caswell, H., F. Reed, S. N. Stephenson, and P. A. Werner. 1973. Photosynthetic pathways and selective herbivory: A hypothesis. The American Naturalist 107:465480 .

Cebrian, J., J. B. Shurin, E. T. Borer, B. J. Cardinale, J. T. Ngai, M. D. Smith, and W. F. Fagan. 2009. Producer nutritional quality controls ecosystem trophic structure. PloS one $4: 1-5$.

Cheplick, G. P. 2010. Limits to local spread in a highly invasive annual grass (Microstegium vimineum). Biological Invasions 12:1759-1771.

Civitello, D. J., S. L. Flory, and K. Clay. 2008. Exotic grass invasion reduces survival of Amblyomma americanum and Dermacentor variabilis Ticks (Acari:Ixodidae). Journal of Medical Entomology 45:867-872.

Couture, J. J., J. S. Servi, and R. L. Lindroth. 2010. Increased nitrogen availability influences predator-prey interactions by altering host-plant quality. Chemoecology 20:277-284.

Cramer, K. L., and A. V. Maywright. 2008. Cold temperature tolerance and distribution of the brown recluse spider Loxosceles reclusa (Araneae, Sicariidae) in Illinois. Journal of Arachnology 36:136-139.

Crooks, J. A. 2002. Characterizing ecosystem-level consequences of biological invasions: The role of ecosystem engineers. Oikos 97:153-166.

Denlinger, D. L. 1980. Seasonal and annual variation of insect abundance in the Nairobi National Park , Kenya. Biotropica 12:100-106.

Denno, R. F., C. Gratton, M. A. Peterson, G. A. Langellotto, D. L. Finke, and A. F. Huberty. 2002. Bottom-up forces mediate natural-enemy impact in a phytophagous insect community. Ecology 83:1443-1458.

Denno, R. F., M. S. Mitter, G. a. Langellotto, C. Gratton, and D. L. Finke. 2004. Interactions between a hunting spider and a web-builder: Consequences of intraguild predation and cannibalism for prey suppression. Ecological Entomology 29:566577.

DeVore, J. L. 2011. An exercise in complexity: Indirect influences of invasion by an exotic grass (Microstegium vimineum) on forest floor food webs. Dissertation. University of Georgia, Athens, GA.

Drake, J. A. 1990. Communities as assembled structures: Do rules govern pattern? Ecology and Evolution 5:159-164. 
Drake, J. A. 1991. Community assembly mechanics and the structure of an experimental species ensemble. American Naturalist 137:1-26.

Ehrenfeld, J. D. 2011. Ecosystem consequences of biological invasions. Annual Reviews in Ecology, Evolution and Systematics 41:59-80.

Ehrenfeld, J. G. 2003. Effects of exotic plant invasions on soil nutrient cycling processes. Ecosystems 6:503-523.

Ehrenfeld, J. G., P. Kourtev, and W. Huang. 2001. Changes in soil functions following invasions of exotic understory plants in deciduous forests. Ecological Applications 11:1287-1300.

Elton, C. 1958. The ecology of invasions by animals and plants. . The University of Chicago Press, Chicago.

Fairbrothers, D. E., and J. R. Gray. 1972. Microstegium vimineum (Trin.) A. Camus (Graminae) in the United States. Bulletin of the Torrey Botanical Club 99:97-100.

Finke, D. L., and R. F. Denno. 2002. Intraguild predation diminished in complexstructured vegetation: Implications for prey suppression. Ecology 83:643-652.

Finke, D. L., and R. F. Denno. 2006. Spatial refuge from intraguild predation: Implications for prey suppression and trophic cascades. Oecologia 149:265-75.

Flory, S. L. 2010. Management of Microstegium vimineum invasions and recovery of resident plant communities. Restoration Ecology 18:103-112.

Flory, S. L., and K. Clay. 2009. Invasive plant removal method determines native plant community responses. Journal of Applied Ecology 46:434-442.

Flory, S. L., and K. Clay. 2010a. Non-native grass invasion suppresses forest succession. Oecologia 164:1029-1038.

Flory, S. L., and K. Clay. 2010b. Non-native grass invasion alters native plant composition in experimental communities. Biological Invasions 12:1285-1294.

Foelix, R. F. 2011. Biology of spidersThird Edic. Oxford University Press, New York, NY.

Gibson, C. W. D., C. Hambler, and V. K. Brown. 1992. Changes in spider Araneae assemblages in relation to succession and grazing management. Journal of Applied Ecology 29:133-142.

Grabowski, J. H., A. R. Hughes, D. L. Kimbro, and L. Kimbro. 2008. Habitat Complexity Influences Cascading Effects of Multiple Predators. Ecology 89:3413-3422. 
Gratton, C., and R. F. Denno. 2003. Inter-year carryover effects of a nutrient pulse on Spartina plants, herbivores, and natural enemies. Ecology 84:2692-2707.

Gratton, C., and R. F. Denno. 2005. Restoration of arthropod assemblages in a Spartina salt marsh following removal of the invasive plant Phragmites australis. Restoration Ecology 13:358-372.

Haddad, N. M., G. M. Crutsinger, K. Gross, J. Haarstad, J. M. H. Knops, and D. Tilman. 2009. Plant species loss decreases arthropod diversity and shifts trophic structure. Ecology letters 12:1029-39.

Hallander, H. 1970. Prey, cannibalism and microhabitat selection in the wolf spiders Pardosa chelata O.F. Muller and P. pullata Clerck. Oikos 21:337-340.

Hartley, M. K., W. E. Rogers, and E. Siemann. 2010. Comparisons of arthropod assemblages on an invasive and native trees: abundance, diversity and damage. Arthropod-Plant Interactions 4:237-245.

Hatley, C. L., and J. A. Macmahon. 1980. Spider community organization: Seasonal variation and the role of vegetation architecture. Environmental Entomology 9:632639.

Heleno, R. H., R. S. Ceia, J. A. Ramos, and J. Memmott. 2008. Effects of alien plants on insect abundance and biomass: A food-web approach. Conservation Biology 23:410-419.

Hobbs, R. J., and S. E. Humphries. 1995. An integrated approach to the ecology and management of plant invasions. Conservation Biology 9:761-770.

Hunt, D., and R. Zaremba. 1992. The northeastward spread of Microstegium vimineum (Poaceae) into New York and adjacent states. Rhodora 94:167-170.

Janssen, A., M. W. Sabelis, S. Magalhaes, M. Montserrat, and T. van der Hammen. 2007. Habitat structure affects intraguild predation. Ecology 88:2713-2719.

Johnson, N. F., and C. Triplehorn. 2005. Borror and DeLong's Introduction to the Study of Insects. Page 8647th Editio. Thomson Brooks/Cole, Belmont.

Kappes, H., R. Lay, and W. Topp. 2007. Changes in different trophic levels of litterdwelling macrofauna associated with giant knotweed invasion. Ecosystems 10:734744.

Kitching, R. 1987. Spatial and temporal variation in food webs in water-filled treeholes. Oikos 48:280-288.

Kneitel, J. M., and T. E. Miller. 2002. Resource and top-predator regulation in the pitcher plant (Sarracenia purpurea) inquiline community. Ecology 83:680-688. 
Lambrinos, J. G. 2000. The impact of the invasive alien grass Cortaderia jubata (Lemoine) Stapf on an endangered mediterranean-type shrubland in California. Diversity and Distributions 6:217-231.

Langellotto, G. a, and R. F. Denno. 2004. Responses of invertebrate natural enemies to complex-structured habitats: A meta-analytical synthesis. Oecologia 139:1-10.

Langellotto, G. a., and R. F. Denno. 2006. Refuge from cannibalism in complexstructured habitats: Implications for the accumulation of invertebrate predators. Ecological Entomology 31:575-581.

Lau, J. A., and S. Y. Strauss. 2005. Insect herbivored drive important indirect effects of exotic plants on native communities. Ecology 86:2990-2997.

Lawton, J. H. 1983. Plant Architecture and the Diversity of Phytophagous Insects. Annual Review of Entomology 28:23-39.

Lawton, J. H., and D. R. Strong. 1981. Community patterns and competiton of folivorous insects. American Naturalist 18:317-338.

Levine, J. M., M. Vilà, C. M. D’Antonio, J. S. Dukes, K. Grigulis, and S. Lavorel. 2003. Mechanisms underlying the impacts of exotic plant invasions. Proceedings of the Royal Society of London 270:775-781.

Lowman, M. D. 1982. Seasonal variation in insect abundance among three Australian rain forests, with particular reference to phytophagous types. Australian Journal of Ecology 7:353-361.

Mack, M. C., and C. M. D'Antonio. 2003. The effects of exotic grasses on litter decomposition in a Hawaiian woodland: The importance of indirect effects. Ecosystems 6:723-738.

Mack, R. N., W. M. Simberloff, H. E. Lonsdale, M. Clout, and F. Bazzaz. 2000. Biotic invasions: Causes, epidemiology, global consequences and control. Issues in Ecology 5:1-20.

Maron, J. L., and M. Marler. 2008. Field-based competitive impacts between invaders and natives at varying resource supply. Journal of Ecology 96:1187-1197.

Marshall, J. M., and D. S. Buckley. 2009. Influence of Microstegium vimineum presence on insect abundance in hardwood forests. Southeastern Naturalist 8:515-526.

Marshall, S. A. 2009. Insects: Their natural history and diversity, 3rd edition. Firefly Books, Buffalo, NY. 
Mayer, P. M., S. J. Tunnell, D. M. Engle, E. E. Jorgensen, and P. Nunn. 2005. Invasive grass alters litter decomposition by influencing macrodetritivores. Ecosystems 8:200-209.

McCune, B., and J. B. Grace. 2002. Nonmetric Multidimensional Scaling. Pages 125-142 Analysis of Ecological Communities. . MJM Software Design, Gleneden Beach, Oregon.

McCune, B., and M. J. Mefford. 1999. PC-ORD. Multivariate analysis of ecological data. . MJM Software Design, Gleneden Beach, Oregon, USA.

McGrath, D. A., and M. A. Binkley. 2009. Microstegium vimineum invasion changes soil chemistry and microarthropod communities in Cumberland Plateau forests. Southeastern Naturalist 8:141-156.

Meiners, S. J. 2001. Effects of plant invasions on the species richness of abandoned agricultural land. Ecography 24:633-644.

Metcalf, J. 2013a. Community level impacts of Microstegium vimineum on athropods in a temperate deciduous forest. Chapter 2: Changes in insect community structure associated with invasion by Microstegium vimineum. Dissertation. University of Louisville, Louisville, KY.

Metcalf, J. 2013b. Community level impacts of Microstegium vimineum on arthropods in a temperate deciduous forest. Chapter 3: Changes in spider community structure associated with Microstegium vimineum invasion. Dissertation. University of Louisville, Louisville, KY.

Mgobozi, M. P., M. J. Somers, and A. S. Dippenaar-Schoeman. 2008. Spider responses to alien plant invasion: The effect of short- and long-term Chromolaena odorata invasion and management. Journal of Applied Ecology 45:1189-1197.

Miyashita, T. 1992. Food limitation of population density in the orb-web spider, Nephila clavata. Res. Popul. Ecol. 34:143-153.

NOAA. 2009. Local climatological data annual summary. Meteorlogical data for 2009, Louisville Kentucky (KSDF).

NOAA. 2010. Local climatological data annual summary with comparative data. Meteorological data for 2010, Louisville Kentucky (KSDF).

NOAA. 2011. Local climatological data annual summary with comparative data. Meteorological data for 2011, Louisville Kentucky (KSDF).

Osenburg, C. W., and G. G. Mittlebach. 1996. The relative importance of resource limitation and predator limitation in food chains. Pages 134-148 in G. A. Polis and 
K. O. Winemiller, editors. Food Webs: Integration of patterns \& dynamics. . Chapman \& Hall, New York, NY.

Oswalt, C. M., and S. N. Oswalt. 2007. Winter litter disturbance facilitates the spread of the nonnative invasive grass Microstegium vimineum (Trin.) A. Camus. Forest Ecology and Management 249:199-203.

Oswalt, C. M., S. N. Oswalt, and W. K. Clatterbuck. 2007. Effects of Microstegium vimineum (Trin.) A. Camus on native woody species density and diversity in a productive mixed-hardwood forest in Tennessee. Forest Ecology and Management 242:727-732.

Pajunen, T., Y. Haiia, E. Halme, J. Niemela, and P. Punttila. 1995. Ground-dwelling spiders (Arachnida, Araneae ) in fragmented old forests and surrounding managed forests in southern Finland. Ecography 18:62-72.

Parr, C. L., B. J. Ryan, and S. a. Setterfield. 2010. Habitat complexity and invasive species: The impacts of Gamba Grass (Adropogon gayanus on invertebrates in and Australian tropical savanna. Biotropica 42:688-696.

Pearson, D. E. 2009. Invasive plant architecture alters trophic interactions by changing predator abundance and behavior. Oecologia 159:549-558.

Pearson, D. E. 2010. Trait- and density-mediated indirect interactions initiated by an exotic invasive plant autogenic ecosystem engineer. The American Naturalist 176:394-403.

Pétillon, J., K. Lambeets, W. Montaigne, J.-P. Maelfait, and D. Bonte. 2010a. Habitat structure modified by an invasive grass enhances inundation withstanding in a saltmarsh wolf spider. Biological Invasions 12:3219-3226.

Pétillon, J., E. Lasne, K. Lambeets, A. Canard, P. Vernon, and F. Ysnel. 2010b. How do alterations in habitat structure by an invasive grass affect salt-marsh resident spiders? Ann. Zool. Fennici 47:79-89.

Post, W. M., and S. L. Pimm. 1983. Community assembly and food web stability. Mathematical Biosciences 64:169-192.

Price, P. W., R. F. Denno, and M. D. Eubanks. 2011. Insect Ecology: Behavior, Populations and Communities. . Cambridge University Press, New York, NY.

Redman, D. 1995. Distribution and habitat types for Nepal Microstegium [ Microstegium vimineum (Trin.) Camus] in Maryland and the District of Columbia. Castanea 60:270-275.

Root, R. B. 1967. The niche exploitation pattern of the Blue-Gray Gnatcatcher. Ecological Monographs 37:317-350. 
Samways, M. J., P. M. Caldwell, and R. Osborn. 1996. Ground-living invertebrate assemblages in native, planted and invasive vegetation in South Africa. Agriculture, Ecosystems and Environment 59:19-32.

Samways, M., and S. Moore. 1991. Influence of exotic conifer patches on grasshopper (Orthoptera) assemblages in a grassland matrix at a recreational resort, Natal, South Africa. Biological Conservation 57:117-137.

Schmitz, O. J., P. A. Hambäck, and A. P. Beckerman. 2000. Trophic cascades in terrestrial systesm: A review of the effects of carnivore removals on plants. American Natuaralist 155:141-153.

Schmitz, O. J., V. Krivan, and O. Ovadia. 2004. Trophic cascades: The primacy of traitmediated indirect interactions. Ecology Letters 7:153-163.

Scott, A. G., G. S. Oxford, and P. a. Selden. 2006. Epigeic spiders as ecological indicators of conservation value for peat bogs. Biological Conservation 127:420 428 .

Shannon, C. 1948. A mathematical theory of communication. The Bell System Technical Journal 27:379-423 and 623-656.

Siemann, E. 1998. Experimental tests of effects of plant productivity and diversity on grassland arthropod diversity. Ecology 79:2057-2070.

Simao, M. C. M., S. L. Flory, and J. A. Rudgers. 2010. Experimental plant invasion reduces arthropod abundance and richness across multiple trophic levels. Oikos 119:1553-1562.

Simberloff, D. 1996. Impacts of introduced species in the United States. Consequences 2:13-23.

Standish, R. J. 2004. Impact of an invasive clonal herb on epigaeic invertebrates in forest remnants in New Zealand. Biological Conservation 116:49-58.

Strauss, S. Y. 1987. Direct and indirect effects of host-plant fertilization on an insect community. Ecology 68:1670-1678.

Strickland, M. S., J. L. Devore, J. C. Maerz, and M. A. Bradford. 2010. Grass invasion of a hardwood forest is associated with declines in belowground carbon pools. Global Change Biology 16:1338-1350.

Strong, D. R. 1992. Are trophic cascades all wet? Differentiation and donor-control in speciose ecosystems. Ecology 73:747-754.

Systat Software Inc. 2009. SYSTAT v. 13. . Chicago IL. 
Tallamy, D. W. 2004. Do alient plants reduce insect biomass? Conservation Biology 18:1689-1692.

Tang, Y., R. J. Warren, T. D. Kramer, and M. A. Bradford. 2012. Plant invasion impacts on arthropod abundance, diversity and feeding consistent across environmental and geographic gradients. Biological Invasions 14:2625-2637.

Topp, W., H. Kappes, and F. Rogers. 2008. Response of ground-dwelling beetle (Coleoptera) assemblages to giant knotweed (Reynoutria spp.) invasion. Biological Invasions 10:381-390.

Ubick, D., P. Paquin, P. E. Cushing, and V. (eds. . Roth. 2005. Spiders of North America - An identification manual. Page 377 pages (D. Ubick, P. Paquin, P. E. Cushing, and V. Roth, Eds.). . American Arachnological Society, Keene (New Hampshire).

Uetz, G. W. 1977. Coexistence in a guild of wandering spiders. Journal of Animal Ecology 46:531-541.

Uetz, G. W., J. Bischoff, and J. Raver. 1992. Survivorship of wolf spiders (Lycosidae) reared on different diets. The Journal of Arachnology 20:207-211.

Uetz, G. W., J. Halaj, and A. B. Cody. 1999. Guild structure of spiders in major crops. The Journal of Arachnology 27:270-280.

USDA. 2008. The PLANTS database.

Werner, E. E., and S. D. Peacor. 2003. A review of trait-mediated indirect interactions in ecological communities. Ecology 84:1083-1100.

Wimp, G. M., S. M. Murphy, D. L. Finke, A. F. Huberty, and R. F. Denno. 2010. Increased primary production shifts the structure and composition of a terrestrial arthropod community. Ecology 91:3303-11.

Winemiller, K. O., and G. A. Polis. 1996. Food Webs: What do they tell us about the world? Pages 1-22 in G. A. Polis and K. O. Winemiller, editors. Food Webs: Integration of patterns \& dynamics. . Chapman \& Hall, New York, NY.

Wu, Y. T., C. H. Wang, X. D. Zhang, B. Zhao, L. F. Jiang, J. K. Chen, and B. Li. 2009. Effects of saltmarsh invasion by Spartina alterniflora on arthropod community structure and diets. Biological Invasions 11:635-649.

Yodzis, P. 1981a. The stability of real ecosystems. Nature 289:674-676.

Yodzis, P. 1981b. The structure of assembled communities. Journal of Theoretical Biology 92:103-117. 
Yoshioka, A., T. Kadoya, S. Suda, and I. Washitani. 2010. Impacts of weeping lovegrass (Eragrostis curvula) invasion on native grasshoppers: responses of habitat generalist and specialist species. Biological Invasions 12:531-539.

Zimmerman, G. M., H. Goetz, and P. W. J. Mielke. 1985. Use of an improved statistical method for group comparisons to study effects of prairie fire. Ecology 66:606-611. 
Appendix I: Mean abundance and biomass for all insects collected May-October 2010-2011 broken down by Family by trap type, invasion status, trophic group, functional guild, order and morpho group

\begin{tabular}{|c|c|c|c|c|c|c|c|c|}
\hline Trap & $\begin{array}{c}\text { Invasion } \\
\text { Status }\end{array}$ & $\begin{array}{l}\text { Trophic } \\
\text { Group }\end{array}$ & Functional Guild & Order & Morpho-group & Family & $\begin{array}{c}\text { Mean } \\
\text { abundance }\end{array}$ & $\begin{array}{c}\text { Mean } \\
\text { Biomass }\end{array}$ \\
\hline \multirow[t]{23}{*}{$\mathrm{PF}$} & Invaded & Carnivore & Parasite & Unknown & Mite & Mite & 1.00 & 0.0001 \\
\hline & & & & & Tick & Ixodidae & 1.60 & 0.0081 \\
\hline & & & Parasitoid & Hymenoptera & Wasp & Braconidae & 1.33 & 0.0006 \\
\hline & & & & & & Diapriidae & 1.00 & 0.0001 \\
\hline & & & & & & Pteromalidae & 1.00 & 0.0003 \\
\hline & & & Predator & Chilopoda & Chilopod & Chilopoda & 1.00 & 0.0075 \\
\hline & & & & Coleoptera & Beetle & Cleridae & 1.00 & 0.0013 \\
\hline & & & & & & Coccinellidae & 1.00 & 0.0010 \\
\hline & & & & & & Histeridae & 1.00 & 0.0047 \\
\hline & & & & & & Staphylinidea & 1.10 & 0.0019 \\
\hline & & & & & Firefly & Lampyridae & 1.00 & 0.0286 \\
\hline & & & & Hemiptera & Assassin Bug & Reduviiadae & 1.00 & 0.0002 \\
\hline & & & & Hymenoptera & Ant & Formicidae & 1.45 & 0.0028 \\
\hline & & & & Opiliones & Harvestman & Phalangidae & 1.61 & 0.0294 \\
\hline & & Detritivore & Scavenger/Shredder & Archeognatha & Bristletail & Machilidae & 1.25 & 0.0126 \\
\hline & & & & Coleoptera & Beetle & Leiodidae & 1.33 & 0.0002 \\
\hline & & & & & & Tenebrionidae & 1.00 & 0.0049 \\
\hline & & & & Collembola & Springtail & Entomobryidae & 1.33 & 0.0003 \\
\hline & & & & Diplopoda & Diplopod & Diplopoda & 1.33 & 0.1045 \\
\hline & & & & Isopoda & Isopod & Isopod & 3.03 & 0.0510 \\
\hline & & & & Orthoptera & Cricket & Rhaphidophoridae & 1.18 & 0.0399 \\
\hline & & Herbivore & Concealed Chewer & Coleoptera & Weevil & Curculionidae & 1.00 & 0.0020 \\
\hline & & & & Diptera & Midge & Ceccidomyidae & 2.00 & 0.0001 \\
\hline
\end{tabular}




\begin{tabular}{|c|c|c|c|c|c|c|c|c|}
\hline Trap & $\begin{array}{c}\text { Invasion } \\
\text { Status }\end{array}$ & $\begin{array}{l}\text { Trophic } \\
\text { Group }\end{array}$ & Functional Guild & Order & Morpho-group & Family & $\begin{array}{c}\text { Mean } \\
\text { abundance }\end{array}$ & $\begin{array}{c}\text { Mean } \\
\text { Biomass }\end{array}$ \\
\hline \multirow[t]{26}{*}{$\mathrm{PF}$} & Invaded & Herbivore & Concealed Chewer & Hymenoptera & Wasp & Eurytomidae & 1.00 & 0.0003 \\
\hline & & & Free-living Chewer & Coleoptera & Beetle & Chrysomelidae & 1.17 & 0.0026 \\
\hline & & & & Hemiptera & Seed bug & Rhyparochromidae & 1.33 & 0.0070 \\
\hline & & & & Hymenoptera & Sawfly & Tenthredinidae & 1.00 & 0.0005 \\
\hline & & & & Lepidoptera & Larva & Lepidoptera Larva & 1.00 & 0.0891 \\
\hline & & & & Orthoptera & Grasshopper & Tetrigidae & 1.00 & 0.0006 \\
\hline & & & & Coleoptera & Larva & Coleoptera larva & 1.00 & 0.0003 \\
\hline & & & Free-living Sap Feeder & Hemiptera & Aphid & Anoeciidae & 1.00 & 0.0002 \\
\hline & & & & & & Aphididae & 1.00 & 0.0001 \\
\hline & & & & & Plant hopper & Delphacidae & 1.00 & 0.0008 \\
\hline & & & & Lepidoptera & Moth & Microlepidoptera & 2.00 & 0.0066 \\
\hline & & & Pollinator & Coleoptera & Beetle & Byturidae & 1.00 & 0.0008 \\
\hline & & Omnivore & Free-living Chewer & Orthoptera & Cricket & Gryllidae & 1.55 & 0.0072 \\
\hline & & & & Diptera & Small Fly & Microdiptera & 1.00 & 0.0024 \\
\hline & Uninvaded & Carnivore & Parasite & Diptera & Mosquito & Culicidae & 1.00 & 0.0005 \\
\hline & & & & Unknown & Mite & Mite & 1.00 & 0.0001 \\
\hline & & & & & Tick & Ixodidae & 1.40 & 0.0033 \\
\hline & & & Parasitoid & Hymenoptera & Wasp & Braconidae & 1.50 & 0.0007 \\
\hline & & & & & & Cynipidae & 1.00 & 0.0001 \\
\hline & & & & & & Pteromalidae & 1.00 & 0.0003 \\
\hline & & & Predator & Chilopoda & Chilopod & Chilopoda & 1.00 & 0.0470 \\
\hline & & & & Coleoptera & Beetle & Coccinellidae & 1.00 & 0.0004 \\
\hline & & & & & & Staphylinidea & 1.00 & 0.0010 \\
\hline & & & & Hymenoptera & Ant & Formicidae & 1.27 & 0.0045 \\
\hline & & & & Opiliones & Harvestman & Phalangidae & 1.79 & 0.0193 \\
\hline & & Detritivore & Scavenger/Shredder & Archeognatha & Bristletail & Machilidae & 2.16 & 0.0184 \\
\hline
\end{tabular}




\begin{tabular}{|c|c|c|c|c|c|c|c|c|}
\hline Trap & $\begin{array}{c}\text { Invasion } \\
\text { Status }\end{array}$ & $\begin{array}{l}\text { Trophic } \\
\text { Group }\end{array}$ & Functional Guild & Order & Morpho-group & Family & $\begin{array}{c}\text { Mean } \\
\text { abundance }\end{array}$ & $\begin{array}{c}\text { Mean } \\
\text { Biomass }\end{array}$ \\
\hline \multirow[t]{20}{*}{$\mathrm{PF}$} & \multirow[t]{20}{*}{ Uninvaded } & \multirow[t]{19}{*}{ Herbivore } & \multirow[t]{6}{*}{ Scavenger/Shredder } & Coleoptera & Beetle & Tenebrionidae & 1.00 & 0.0012 \\
\hline & & & & Collembola & Springtail & Entomobryidae & 1.50 & 0.0005 \\
\hline & & & & Diplopoda & Diplopod & Diplopoda & 1.50 & 0.6907 \\
\hline & & & & Isopoda & Isopod & Isopod & 3.07 & 0.0569 \\
\hline & & & & Orthoptera & Cricket & Rhaphidophoridae & 1.21 & 0.0332 \\
\hline & & & & Diptera & Larva & Diptera Larva & 1.00 & 0.0010 \\
\hline & & & Concealed Chewer & Hymenoptera & Wasp & Eurytomidae & 2.00 & 0.0005 \\
\hline & & & \multirow[t]{9}{*}{ Free-living Chewer } & \multirow[t]{5}{*}{ Coleoptera } & \multirow[t]{3}{*}{ Beetle } & Chrysomelidae & 1.40 & 0.0034 \\
\hline & & & & & & Scarabeidae & 2.75 & 0.0212 \\
\hline & & & & & & Mordellidae & 1.00 & 0.0006 \\
\hline & & & & & Larva & Coleoptera larva & 1.00 & 0.0014 \\
\hline & & & & & Weevil & Bruchidae & 1.00 & 0.0015 \\
\hline & & & & Hemiptera & Seed bug & Rhyparochromidae & 1.00 & 0.0013 \\
\hline & & & & Hymenoptera & Sawfly & Tenthredinidae & 1.00 & 0.0001 \\
\hline & & & & Lepidoptera & Larva & Lepidoptera Larva & 1.00 & 0.0084 \\
\hline & & & & Orthoptera & Grasshopper & Tetrigidae & 2.00 & 0.0015 \\
\hline & & & \multirow[t]{3}{*}{ Free-living Sap Feeder } & \multirow[t]{3}{*}{ Hemiptera } & Aphid & Aphididae & 1.00 & 0.0001 \\
\hline & & & & & Leaf Hopper & Cicadellidae & 1.00 & 0.0002 \\
\hline & & & & & Plant hopper & Delphacidae & 1.00 & 0.0003 \\
\hline & & Omnivore & Free-living Chewer & Orthoptera & Cricket & Gryllidae & 1.24 & 0.0151 \\
\hline \multirow[t]{5}{*}{ SN } & \multirow[t]{5}{*}{ Invaded } & \multirow[t]{5}{*}{ Carnivore } & \multirow[t]{5}{*}{ Parasite } & Diptera & Mosquito & Culicidae & 1.51 & 0.0008 \\
\hline & & & & Hymenoptera & Wasp & Eupelmidae & 1.00 & 0.0001 \\
\hline & & & & & & Orussidae & 1.17 & 0.0003 \\
\hline & & & & Unknown & Mite & Mite & 1.33 & 0.0001 \\
\hline & & & & & Tick & Ixodidae & 1.00 & 0.0001 \\
\hline
\end{tabular}




\begin{tabular}{|c|c|c|c|c|c|c|c|c|}
\hline Trap & $\begin{array}{c}\text { Invasion } \\
\text { Status }\end{array}$ & $\begin{array}{l}\text { Trophic } \\
\text { Group }\end{array}$ & Functional Guild & Order & Morpho-group & Family & $\begin{array}{c}\text { Mean } \\
\text { abundance }\end{array}$ & $\begin{array}{c}\text { Mean } \\
\text { Biomass }\end{array}$ \\
\hline \multirow[t]{24}{*}{$\overline{\mathrm{SN}}$} & Invaded & Carnivore & Parasitoid & Pymenoptera & Wasp & Bethylidae & 2.00 & 0.0008 \\
\hline & & & & & & Braconidae & 2.01 & 0.0005 \\
\hline & & & & & & Chalcididae & 1.00 & 0.0007 \\
\hline & & & & & & Chrysididae & 1.17 & 0.0006 \\
\hline & & & & Hymenoptera & Wasp & Cynipidae & 1.00 & 0.0001 \\
\hline & & & & & & Diapriidae & 1.38 & 0.0001 \\
\hline & & & & & & Encyrtidae & 1.50 & 0.0004 \\
\hline & & & & & & Eulophidae & 1.14 & 0.0005 \\
\hline & & & & & & Evaniidae & 1.00 & 0.0004 \\
\hline & & & & & & Ichneumonidae & 1.31 & 0.0043 \\
\hline & & & & & & Pteromalidae & 2.00 & 0.0002 \\
\hline & & & & & & Tiphiidae & 1.50 & 0.0027 \\
\hline & & & & & Larva & Hymenoptera Larva & 1.33 & 0.0020 \\
\hline & & & Predator & Coleoptera & Beetle & Cantharidae & 1.00 & 0.0045 \\
\hline & & & & & & Ciccindellidae & 1.00 & 0.0013 \\
\hline & & & & & & Cleridae & 1.00 & 0.0010 \\
\hline & & & & & & Coccinellidae & 1.40 & 0.0055 \\
\hline & & & & & & Histeridae & 1.00 & 0.0018 \\
\hline & & & & & & Staphylinidea & 1.00 & 0.0004 \\
\hline & & & & & Firefly & Lampyridae & 1.50 & 0.0155 \\
\hline & & & & Hemiptera & Ambush Bug & Phymatidae & 1.25 & 0.0020 \\
\hline & & & & & Assassin Bug & Reduviiadae & 1.76 & 0.0044 \\
\hline & & & & & Damsel Bug & Nabidae & 2.00 & 0.0006 \\
\hline & & & & & Stinkbug & Pentatomidae & 1.25 & 0.0089 \\
\hline
\end{tabular}




\begin{tabular}{|c|c|c|c|c|c|c|c|c|}
\hline Trap & $\begin{array}{c}\text { Invasion } \\
\text { Status }\end{array}$ & $\begin{array}{l}\text { Trophic } \\
\text { Group }\end{array}$ & Functional Guild & Order & Morpho-group & Family & $\begin{array}{c}\text { Mean } \\
\text { abundance }\end{array}$ & $\begin{array}{c}\text { Mean } \\
\text { Biomass }\end{array}$ \\
\hline \multirow[t]{25}{*}{$\mathrm{SN}$} & Invaded & Carnivore & Predator & Hymenoptera & Ant & Formicidae & 7.84 & 0.0039 \\
\hline & & & & & Wasp & Crabrionidae & 1.33 & 0.0015 \\
\hline & & & & & & Pompilidae & 1.00 & 0.0005 \\
\hline & & & & & & Sphecidae & 1.00 & 0.0003 \\
\hline & & & & & & Vespidae & 1.00 & 0.0080 \\
\hline & & & & Mantodea & Mantiss & Mantidae & 1.00 & 0.2433 \\
\hline & & & & Neuroptera & Brown Lacewing & Hemerobiidae & 1.00 & 0.0022 \\
\hline & & & & & Green Lacewing & Chrysopidea & 1.00 & 0.0049 \\
\hline & & & & Orthoptera & Grasshopper & Grylacrididae & 1.00 & 0.0162 \\
\hline & & & & & Katydid & Tettigonidae & 2.33 & 0.0270 \\
\hline & & Detritivore & Scavenger/Shredder & Archeognatha & Bristletail & Machilidae & 1.00 & 0.0062 \\
\hline & & & & Blattodea & Cockroach & Blattellidae & 1.00 & 0.0045 \\
\hline & & & & Coleoptera & Beetle & Endomychidae & 1.00 & 0.0006 \\
\hline & & & & & & Eucnemidae & 1.25 & 0.0025 \\
\hline & & & & & & Leiodidae & 1.45 & 0.0012 \\
\hline & & & & & & Tenebrionidae & 2.15 & 0.0015 \\
\hline & & & & Collembola & Springtail & Entomobryidae & 1.80 & 0.0008 \\
\hline & & & & Diptera & Midge & Mycetophilidae & 2.00 & 0.0003 \\
\hline & & & & Isopoda & Isopod & Isopod & 1.00 & 0.0474 \\
\hline & & & & Orthoptera & Cricket & Rhaphidophoridae & 1.33 & 0.0328 \\
\hline & & & & Psocoptera & Barklice & Amphipsocidae & 1.00 & 0.0004 \\
\hline & & & & & & Mesopsocidae & 1.00 & 0.0007 \\
\hline & & & & & & Myopsocidae & 1.00 & 0.0003 \\
\hline & & & & & & Peripsocidae & 1.00 & 0.0001 \\
\hline & & & & Diptera & Larva & Diptera Larva & 1.00 & 0.0017 \\
\hline
\end{tabular}




\begin{tabular}{|c|c|c|c|c|c|c|c|c|}
\hline Trap & $\begin{array}{c}\text { Invasion } \\
\text { Status }\end{array}$ & $\begin{array}{l}\text { Trophic } \\
\text { Group }\end{array}$ & Functional Guild & Order & Morpho-group & Family & $\begin{array}{c}\text { Mean } \\
\text { abundance }\end{array}$ & $\begin{array}{c}\text { Mean } \\
\text { Biomass }\end{array}$ \\
\hline \multirow[t]{26}{*}{ SN } & Invaded & Herbivore & Concealed Chewer & Coleoptera & Weevil & Curculionidae & 1.82 & 0.0024 \\
\hline & & & & Diptera & Midge & Ceccidomyidae & 2.00 & 0.0001 \\
\hline & & & & Hymenoptera & Horntail & Siricidae & 1.00 & 0.0001 \\
\hline & & & & & Wasp & Eurytomidae & 1.38 & 0.0003 \\
\hline & & & Free-living Chewer & Coleoptera & Beetle & Aderidae & 1.00 & 0.0004 \\
\hline & & & & & & Anobiidae & 1.00 & 0.0001 \\
\hline & & & & & & Buprestidae & 2.00 & 0.0020 \\
\hline & & & & & & Cerambycidae & 1.40 & 0.0044 \\
\hline & & & & & & Chrysomelidae & 1.56 & 0.0045 \\
\hline & & & & & & Elateridae & 1.00 & 0.0086 \\
\hline & & & & & & Ptilodactylidae & 1.67 & 0.0031 \\
\hline & & & & & & Scarabeidae & 1.60 & 0.0083 \\
\hline & & & & & & Mordellidae & 1.79 & 0.0014 \\
\hline & & & & & Larva & Coleoptera larva & 1.00 & 0.0063 \\
\hline & & & & & Weevil & Attelabidae & 1.00 & 0.0011 \\
\hline & & & & & & Bruchidae & 1.44 & 0.0023 \\
\hline & & & & & & Curculionidae & 1.00 & 0.0003 \\
\hline & & & & Diptera & Crane Fly & Tipulidae & 1.39 & 0.0018 \\
\hline & & & & Hemiptera & Seed bug & Rhyparochromidae & 3.03 & 0.0059 \\
\hline & & & & & & Lygaeidae & 1.00 & 0.0001 \\
\hline & & & & Hymenoptera & Sawfly & Pamphiliidae & 1.00 & 0.0012 \\
\hline & & & & & & Tenthredinidae & 1.00 & 0.0012 \\
\hline & & & & Lepidoptera & Larva & Lepidoptera Larva & 1.94 & 0.0249 \\
\hline & & & & Mecoptera & Scorpion fly & Panorpidae & 1.25 & 0.0116 \\
\hline & & & & Orthoptera & Grasshopper & Acrididae & 1.92 & 0.0249 \\
\hline & & & & & & Tetrigidae & 1.38 & 0.0227 \\
\hline
\end{tabular}




\begin{tabular}{|c|c|c|c|c|c|c|c|c|}
\hline Trap & $\begin{array}{c}\text { Invasion } \\
\text { Status }\end{array}$ & $\begin{array}{l}\text { Trophic } \\
\text { Group }\end{array}$ & Functional Guild & Order & Morpho-group & Family & $\begin{array}{c}\text { Mean } \\
\text { abundance }\end{array}$ & $\begin{array}{c}\text { Mean } \\
\text { Biomass }\end{array}$ \\
\hline \multirow[t]{25}{*}{$\mathrm{SN}$} & Invaded & Herbivore & Free-living Sap Feeder & Hemiptera & Aphid & Anoeciidae & 1.00 & 0.0003 \\
\hline & & & & & & Aphididae & 2.27 & 0.0003 \\
\hline & & & & & Lace Bug & Tingidae & 1.00 & 0.0003 \\
\hline & & & & & Leaf Hopper & Cicadellidae & 6.06 & 0.0095 \\
\hline & & & & & Negro bug & Thyreocoridae & 1.93 & 0.0050 \\
\hline & & & & & Plant hopper & Caliscellidae & 11.50 & 0.0173 \\
\hline & & & & & Plant hopper & Delphacidae & 3.02 & 0.0018 \\
\hline & & & & & & Derbidae & 4.00 & 0.0062 \\
\hline & & & & & & Dictyophoridae & 1.00 & 0.0060 \\
\hline & & & & & & Issidae & 1.50 & 0.0078 \\
\hline & & & & & Spittle bug & Cercopidae & 4.16 & 0.0214 \\
\hline & & & & & Tree Hopper & Membracidae & 1.82 & 0.0054 \\
\hline & & & & & Whitefly & Aleyrodidae & 1.00 & 0.0003 \\
\hline & & & & Lepidoptera & Moth & Microlepidoptera & 1.39 & 0.0113 \\
\hline & & & & Thysanoptera & Thrips & Thripidae & 1.00 & 0.0001 \\
\hline & & & Pollinator & Coleoptera & Beetle & Byturidae & 1.25 & 0.0022 \\
\hline & & & & Hymenoptera & Bee & Apidae & 1.00 & 0.0429 \\
\hline & & & & & & Halictidae & 1.00 & 0.0035 \\
\hline & & Omnivore & Free-living Chewer & Orthoptera & Cricket & Gryllidae & 1.77 & 0.0108 \\
\hline & & & & Diptera & Large Fly & Macrodiptera & 3.81 & 0.0052 \\
\hline & & & & & Small Fly & Microdiptera & 5.57 & 0.0020 \\
\hline & Uninvaded & Carnivore & Parasite & Diptera & Mosquito & Culicidae & 1.35 & 0.0017 \\
\hline & & & & Hymenoptera & Wasp & Eupelmidae & 1.00 & 0.0001 \\
\hline & & & & & & Orussidae & 1.00 & 0.0001 \\
\hline & & & & Unknown & Tick & Ixodidae & 1.00 & 0.0020 \\
\hline
\end{tabular}




\begin{tabular}{|c|c|c|c|c|c|c|c|c|}
\hline Trap & $\begin{array}{c}\text { Invasion } \\
\text { Status } \\
\end{array}$ & $\begin{array}{l}\text { Trophic } \\
\text { Group }\end{array}$ & Functional Guild & Order & Morpho-group & Family & $\begin{array}{c}\text { Mean } \\
\text { abundance }\end{array}$ & $\begin{array}{c}\text { Mean } \\
\text { Biomass }\end{array}$ \\
\hline \multirow[t]{26}{*}{$\mathrm{SN}$} & Uninvaded & Carnivore & Parasitoid & Hymenoptera & Wasp & Bethylidae & 1.00 & 0.0001 \\
\hline & & & & & & Braconidae & 2.17 & 0.0007 \\
\hline & & & & & & Chalcididae & 1.75 & 0.0002 \\
\hline & & & & & & Chrysididae & 1.75 & 0.0026 \\
\hline & & & & & & Cynipidae & 1.00 & 0.0003 \\
\hline & & & & & & Diapriidae & 1.44 & 0.0002 \\
\hline & & & & & & Encyrtidae & 1.29 & 0.0002 \\
\hline & & & & & & Eulophidae & 1.50 & 0.0003 \\
\hline & & & & & & Evaniidae & 1.00 & 0.0001 \\
\hline & & & & & & Ichneumonidae & 1.43 & 0.0050 \\
\hline & & & & & & Pteromalidae & 1.38 & 0.0002 \\
\hline & & & & & & Tiphiidae & 1.20 & 0.0007 \\
\hline & & & Predator & Coleoptera & Beetle & Coccinellidae & 1.00 & 0.0084 \\
\hline & & & & & & Histeridae & 1.00 & 0.0009 \\
\hline & & & & & & Staphylinidea & 1.00 & 0.0007 \\
\hline & & & & & Firefly & Lampyridae & 1.25 & 0.0106 \\
\hline & & & & Hemiptera & Ambush Bug & Reduviiadae & 1.00 & 0.0032 \\
\hline & & & & & Assassin Bug & Reduviiadae & 1.44 & 0.0030 \\
\hline & & & & & Stinkbug & Pentatomidae & 1.00 & 0.0185 \\
\hline & & & & Hymenoptera & Ant & Formicidae & 7.07 & 0.0034 \\
\hline & & & & & Larva & Hymenoptera Larva & 1.00 & 0.0080 \\
\hline & & & & & Wasp & Crabrionidae & 1.50 & 0.0045 \\
\hline & & & & & & Pompilidae & 1.00 & 0.0035 \\
\hline & & & & & & Vespidae & 1.00 & 0.0030 \\
\hline & & & & Neuroptera & Brown Lacewing & Hemerobiidae & 1.00 & 0.0031 \\
\hline & & & & Opiliones & Harvestman & Phalangidae & 2.25 & 0.0479 \\
\hline
\end{tabular}




\begin{tabular}{|c|c|c|c|c|c|c|c|c|}
\hline Trap & $\begin{array}{c}\text { Invasion } \\
\text { Status }\end{array}$ & $\begin{array}{l}\text { Trophic } \\
\text { Group }\end{array}$ & Functional Guild & Order & $\begin{array}{l}\text { Morpho- } \\
\text { group }\end{array}$ & Family & $\begin{array}{c}\text { Mean } \\
\text { abundance }\end{array}$ & $\begin{array}{c}\text { Mean } \\
\text { Biomass }\end{array}$ \\
\hline \multirow[t]{24}{*}{$\mathrm{SN}$} & Uninvaded & Carnivore & Predator & Orthoptera & Katydid & Tettigonidae & 1.06 & 0.0035 \\
\hline & & Detritivore & Scavenger/Shredder & Blattodea & Cockroach & Blattidae & 1.00 & 0.0007 \\
\hline & & & & Coleoptera & Beetle & Leiodidae & 1.00 & 0.0005 \\
\hline & & & & & & Tenebrionidae & 1.70 & 0.0018 \\
\hline & & & & Collembola & Springtail & Entomobryidae & 1.73 & 0.0007 \\
\hline & & & & Diptera & Midge & Mycetophilidae & 1.00 & 0.0010 \\
\hline & & & & Diptera & Larva & Diptera Larva & 5.00 & 0.0006 \\
\hline & & & & Isopoda & Isopod & Isopod & 1.00 & 0.0312 \\
\hline & & & & Mecoptera & Larva & Panorpid Larva & 1.00 & 0.0058 \\
\hline & & & & Orthoptera & Cricket & Rhaphidophoridae & 1.00 & 0.0063 \\
\hline & & & & Psocoptera & Barklice & Amphipsocidae & 1.00 & 0.0008 \\
\hline & & & & & & Peripsocidae & 1.00 & 0.0003 \\
\hline & & Herbivore & Concealed Chewer & Coleoptera & Weevil & Curculionidae & 1.33 & 0.0012 \\
\hline & & & & Hymenoptera & Wasp & Eurytomidae & 1.60 & 0.0002 \\
\hline & & & Free-living Chewer & Coleoptera & Beetle & Buprestidae & 1.00 & 0.0015 \\
\hline & & & & & & Cerambycidae & 1.00 & 0.0048 \\
\hline & & & & & & Chrysomelidae & 1.63 & 0.0036 \\
\hline & & & & & & Elateridae & 1.00 & 0.0106 \\
\hline & & & & & & Mordellidae & 1.53 & 0.0015 \\
\hline & & & & & & Ptilodactylidae & 1.00 & 0.0009 \\
\hline & & & & & & Scarabeidae & 1.00 & 0.0009 \\
\hline & & & & & Larva & Coleoptera larva & 2.67 & 0.0026 \\
\hline & & & & & Weevil & Bruchidae & 1.00 & 0.0020 \\
\hline & & & & Diptera & Crane Fly & Tipulidae & 1.33 & 0.0031 \\
\hline
\end{tabular}




\begin{tabular}{|c|c|c|c|c|c|c|c|c|}
\hline Trap & $\begin{array}{c}\text { Invasion } \\
\text { Status }\end{array}$ & $\begin{array}{l}\text { Trophic } \\
\text { Group }\end{array}$ & Functional Guild & Order & Morpho-group & Family & $\begin{array}{c}\text { Mean } \\
\text { abundance }\end{array}$ & $\begin{array}{c}\text { Mean } \\
\text { Biomass }\end{array}$ \\
\hline \multirow[t]{23}{*}{$\mathrm{SN}$} & " Uninvaded & Herbivore & Free-living Chewer & Hemiptera & Seed bug & Rhyparochromidae & 2.80 & 0.0037 \\
\hline & & & & Hymenoptera & Sawfly & Tenthredinidae & 1.00 & 0.0017 \\
\hline & & & & Lepidoptera & Larva & Lepidoptera Larva & 1.90 & 0.0105 \\
\hline & & & & Orthoptera & Grasshopper & Acrididae & 1.75 & 0.0160 \\
\hline & & & & & & Tetrigidae & 1.08 & 0.0172 \\
\hline & & & Free-living Sap Feeder & Hemiptera & Aphid & Anoeciidae & 2.00 & 0.0006 \\
\hline & & & & & & Aphididae & 3.25 & 0.0003 \\
\hline & & & & & Lace Bug & Tingidae & 2.20 & 0.0006 \\
\hline & & & & & Larva & Hemipteran Larva & 1.00 & 0.0003 \\
\hline & & & & & Leaf Hopper & Cicadellidae & 3.18 & 0.0051 \\
\hline & & & & & Negro bug & Thyreocoridae & 1.43 & 0.0039 \\
\hline & & & & & Plant hopper & Caliscellidae & 3.50 & 0.0057 \\
\hline & & & & & & Cixiidae & 1.00 & 0.0006 \\
\hline & & & & & & Delphacidae & 2.82 & 0.0015 \\
\hline & & & & & & Derbidae & 1.00 & 0.0014 \\
\hline & & & & & & Issidae & 1.00 & 0.0103 \\
\hline & & & & & Spittle bug & Cercopidae & 1.68 & 0.0071 \\
\hline & & & & & Tree Hopper & Membracidae & 2.20 & 0.0121 \\
\hline & & & & & Whitefly & Aleyrodidae & 1.00 & 0.0002 \\
\hline & & & & Lepidoptera & Moth & Microlepidoptera & 1.41 & 0.0076 \\
\hline & & & & Thysanoptera & Thrips & Thripidae & 1.00 & 0.0003 \\
\hline & & & Pollinator & Coleoptera & Beetle & Byturidae & 1.33 & 0.0019 \\
\hline & & & & Hymenoptera & Bee & Halictidae & 1.00 & 0.0027 \\
\hline
\end{tabular}




\begin{tabular}{|c|c|c|c|c|c|c|c|c|}
\hline Trap & $\begin{array}{c}\text { Invasion } \\
\text { Status }\end{array}$ & $\begin{array}{l}\text { Trophic } \\
\text { Group }\end{array}$ & Functional Guild & Order & Morpho-group & Family & $\begin{array}{c}\text { Mean } \\
\text { abundance }\end{array}$ & $\begin{array}{c}\text { Mean } \\
\text { Biomass }\end{array}$ \\
\hline \multirow[t]{3}{*}{$\overline{\mathrm{SN}}$} & Uninvaded & Omnivore & Free-living Chewer & Orthoptera & Cricket & Gryllidae & 1.37 & 0.0079 \\
\hline & & & & Diptera & Large Fly & Macrodiptera & 2.28 & 0.0064 \\
\hline & & & & & Small Fly & Microdiptera & 4.74 & 0.0011 \\
\hline
\end{tabular}


Appendix II: Mean abundance of spiders collected May-October 2010-2011 broken down by trap type, invasion status, functional guild, and Genus and morpho group for Adults, Immature and Totals

\begin{tabular}{|c|c|c|c|c|c|c|c|}
\hline Trap Type & $\begin{array}{c}\text { Invasion } \\
\text { Status }\end{array}$ & $\begin{array}{l}\text { Functional } \\
\text { Guild }\end{array}$ & Family & Genus & $\begin{array}{l}\text { Mean } \\
\text { Adult }\end{array}$ & $\begin{array}{c}\text { Mean } \\
\text { Immature }\end{array}$ & $\begin{array}{c}\text { Mean } \\
\text { Abundance }\end{array}$ \\
\hline \multirow[t]{24}{*}{$\mathrm{PF}$} & Invaded & Ambusher & Philodromidae & Philodromus & 1 & 1.5 & 1.4 \\
\hline & & & & Thanatus & 0 & 1 & 1 \\
\hline & & & Pisauridae & Pisaurina & 0 & 1 & 1 \\
\hline & & & Thomisidae & Coriarachne & 0 & 1 & 1 \\
\hline & & & & Mecaphesa & 2 & 1 & 1.5 \\
\hline & & & & Misumena & 0 & 1.2 & 1.2 \\
\hline & & & & Misumenops & 2 & 0 & 2 \\
\hline & & & & Tmarus & 1 & 0 & 1 \\
\hline & & & & Unknown & 0 & 1 & 1 \\
\hline & & Folliage Runner & Clubionidae & Clubiona & 1.4 & 1.5 & 1.4 \\
\hline & & Ground Runner & Gnaphosidae & Drassyllus & 1 & 0 & 1 \\
\hline & & & & Gnaphosa & 1.2 & 0 & 1.2 \\
\hline & & & Lycosidae & Hogna & 0 & 1 & 1 \\
\hline & & & & Lycosa & 0 & 1 & 1 \\
\hline & & & & Pardosa & 1.1 & 1.1 & 1.1 \\
\hline & & & & Pirata & 1.32 & 1 & 1.3 \\
\hline & & & & Schizocosa & 1.1 & 0 & 1.1 \\
\hline & & & & Trebacosa & 1 & 0 & 1 \\
\hline & & & & Unknown & 0 & 1 & 1 \\
\hline & & Orb Weaver & Araneidae & Cyclosa & 1 & 0 & 1 \\
\hline & & & Tetragnathidae & Leucauge & 1 & 0 & 1 \\
\hline & & & & Tetragnatha & 0 & 1 & 1 \\
\hline & & Sheet Web Builder & Agelenidae & Agelenopsis & 1 & 1 & 1 \\
\hline & & Space Web Builder & Pholcidae & Pholcus & 1 & 0 & 1 \\
\hline
\end{tabular}




\begin{tabular}{|c|c|c|c|c|c|c|c|}
\hline Trap Type & $\begin{array}{c}\text { Invasion } \\
\text { Status }\end{array}$ & $\begin{array}{l}\text { Functional } \\
\text { Guild }\end{array}$ & Family & Genus & $\begin{array}{l}\text { Mean } \\
\text { Adult }\end{array}$ & $\begin{array}{c}\text { Mean } \\
\text { Immature }\end{array}$ & $\begin{array}{c}\text { Mean } \\
\text { Abundance }\end{array}$ \\
\hline \multirow[t]{26}{*}{$\mathrm{PF}$} & Invaded & Stalker & Mimetidae & Mimetus & 1 & 0 & 1 \\
\hline & & & Oxyopidae & Oxyopes & 1.666666667 & 1 & 1.4 \\
\hline & & & Salticidae & Eris & 1 & 1.5 & 1.166666667 \\
\hline & & & & Pellenes & 2 & 0 & 2 \\
\hline & & & & Sassacus & 1.2 & 1 & 1.166666667 \\
\hline & & & & Thiodina & 1 & 1 & 1 \\
\hline & & & & Unknown & 0 & 1 & 1 \\
\hline & & & & Zygoballus & 1.333333333 & 0 & 1.333333333 \\
\hline & & Wandering Sheet Weaver & Linyphiidae & Agyneta & 1 & 0 & 1 \\
\hline & & & & Bathyphantes & 1 & 0 & 1 \\
\hline & & & & Drapestisca & 1 & 1 & 1 \\
\hline & & & & Horcotes & 1 & 0 & 1 \\
\hline & & & & Lepthyphantes & 1 & 0 & 1 \\
\hline & & & & Neriene & 1.5 & 0 & 1.5 \\
\hline & & & & Unknown & 1 & 1 & 1 \\
\hline & Uninvaded & Ambusher & Philodromidae & Philodromus & 1 & 1 & 1 \\
\hline & & & & Unknown & 0 & 1 & 1 \\
\hline & & & Pisauridae & Pisaurina & 0 & 1 & 1 \\
\hline & & & Thomisidae & Mecaphesa & 0 & 1 & 1 \\
\hline & & & & Misumena & 2 & 1 & 1.5 \\
\hline & & & & Misumenops & 1 & 0 & 1 \\
\hline & & & & Unknown & 0 & 2 & 2 \\
\hline & & Folliage Runner & Clubionidae & Clubiona & 1 & 1 & 1 \\
\hline & & Ground Runner & Gnaphosidae & Drassyllus & 1.2 & 0 & 1.2 \\
\hline & & & & Gnaphosa & 1 & 1.5 & 1.142857143 \\
\hline & & & & Unknown & 0 & 1 & 1 \\
\hline
\end{tabular}




\begin{tabular}{|c|c|c|c|c|c|c|c|}
\hline Trap Type & $\begin{array}{l}\text { Invasion } \\
\text { Status }\end{array}$ & $\begin{array}{l}\text { Functional } \\
\text { Guild }\end{array}$ & Family & Genus & $\begin{array}{l}\text { Mean } \\
\text { Adult }\end{array}$ & $\begin{array}{c}\text { Mean } \\
\text { Immature }\end{array}$ & $\begin{array}{c}\text { Mean } \\
\text { Abundance }\end{array}$ \\
\hline \multirow[t]{21}{*}{$\overline{\mathrm{PF}}$} & Uninvaded & Ground Runner & Lycosidae & Allocosa & 1 & 0 & 1 \\
\hline & & & & Pardosa & 1 & 1.25 & 1.090909091 \\
\hline & & & & Pirata & 1.461538462 & 1 & 1.4 \\
\hline & & & & Schizocosa & 1.181818182 & 0 & 1.181818182 \\
\hline & & & & Unknown & 0 & 1 & 1 \\
\hline & & & Oonopidae & Orchestina & 1 & 0 & 1 \\
\hline & & Orb Weaver & Araneidae & Acanthepiera & 1 & 0 & 1 \\
\hline & & & & Araneus & 1 & 0 & 1 \\
\hline & & Sheet Web Builder & Agelenidae & Agelenopsis & 1 & 0 & 1 \\
\hline & & Space Web Builder & Pholcidae & Unknown & 1 & 0 & 1 \\
\hline & & Stalker & Oxyopidae & Unknown & 0 & 0 & 1 \\
\hline & & & Salticidae & Eris & 1 & 0 & 1 \\
\hline & & & & Salticus & 1 & 0 & 1 \\
\hline & & & & Sassacus & 1 & 0 & 1 \\
\hline & & & & Thiodina & 1.5 & 0 & 1.5 \\
\hline & & & & Unknown & 1 & 0 & 1 \\
\hline & & & & Zygoballus & 1 & 0 & 1 \\
\hline & & Wandering Sheet Weaver & Linyphiidae & Agyneta & 1 & 0 & 1 \\
\hline & & & & Bathyphantes & 2 & 0 & 2 \\
\hline & & & & Neriene & 1 & 0 & 1 \\
\hline & & & & Unknown & 1 & 1 & 1 \\
\hline \multirow[t]{3}{*}{$\mathrm{SN}$} & Invaded & Ambusher & Philodromidae & Philodromus & 1.133333333 & 1.6 & 1.366666667 \\
\hline & & & & Tibellus & 1 & 0 & 1 \\
\hline & & & Pisauridae & Pisaurina & 2.3 & 2.8 & 2.528735632 \\
\hline
\end{tabular}




\begin{tabular}{|c|c|c|c|c|c|c|c|}
\hline Trap Type & $\begin{array}{c}\text { Invasion } \\
\text { Status }\end{array}$ & $\begin{array}{l}\text { Functional } \\
\text { Guild }\end{array}$ & Family & Genus & $\begin{array}{l}\text { Mean } \\
\text { Adult }\end{array}$ & $\begin{array}{c}\text { Mean } \\
\text { Immature }\end{array}$ & $\begin{array}{c}\text { Mean } \\
\text { Abundance }\end{array}$ \\
\hline \multirow[t]{25}{*}{$\mathrm{SN}$} & Invaded & Ambusher & Thomisidae & Mecaphesa & 1.266666667 & 1.710526316 & 1.58490566 \\
\hline & & & & Misomenoides & 0 & 1 & 1 \\
\hline & & & & Misumena & 1 & 1.428571429 & 1.25 \\
\hline & & & & Misumenops & 1 & 0 & 1 \\
\hline & & & & Tmarus & 2 & 0 & 2 \\
\hline & & & & Unknown & 0 & 1 & 1 \\
\hline & & Folliage Runner & Clubionidae & Clubiona & 2.142857143 & 1.588235294 & 1.8125 \\
\hline & & & & Unknown & 0 & 3.4 & 3.4 \\
\hline & & & Miturgidae & Cheiracanthium & 1 & 0 & 1 \\
\hline & & & & Unknown & 0 & 1 & 1 \\
\hline & & Ground Runner & Ctenidae & Anahita & 1.5 & 1 & 1.25 \\
\hline & & & Gnaphoside & Drassyllus & 1.2 & 2 & 1.272727273 \\
\hline & & & & Gnaphosa & 1.090909091 & 1 & 1.071428571 \\
\hline & & & & Sergiolus & 1 & 0 & 1 \\
\hline & & & & Unknown & 0 & 2 & 2 \\
\hline & & & Lycosidae & Allocosa & 1 & 0 & 1 \\
\hline & & & & Hogna & 1.5 & 0 & 1.5 \\
\hline & & & & Pardosa & 1.25 & 1 & 1.166666667 \\
\hline & & & & Pirata & 1 & 1 & 1 \\
\hline & & & & Schizocosa & 1 & 0 & 1 \\
\hline & & Orb Weaver & Araneidae & Araneus & 1.695652174 & 1 & 1.615384615 \\
\hline & & & & Araniella & 1.5 & 0 & 1.5 \\
\hline & & & & Argiope & 1 & 1 & 1 \\
\hline & & & & Larinoides & 1 & 0 & 1 \\
\hline & & & & Mangora & 1 & 0 & 1 \\
\hline
\end{tabular}




\begin{tabular}{|c|c|c|c|c|c|c|c|}
\hline Trap Type & $\begin{array}{c}\text { Invasion } \\
\text { Status }\end{array}$ & $\begin{array}{c}\text { Functional } \\
\text { Guild }\end{array}$ & Family & Genus & $\begin{array}{l}\text { Mean } \\
\text { Adult }\end{array}$ & $\begin{array}{c}\text { Mean } \\
\text { Immature }\end{array}$ & $\begin{array}{c}\text { Mean } \\
\text { Abundance }\end{array}$ \\
\hline \multirow[t]{24}{*}{$\mathrm{SN}$} & Invaded & Orb Weaver & Araneidae & Micrathena & 1 & 0 & 1 \\
\hline & & & & Unknown & 2 & 1.5 & 1.4 \\
\hline & & & & Verrucosa & 1 & 0 & 1 \\
\hline & & & & Zygiella & 1.5 & 0 & 1.5 \\
\hline & & & Tetragnathidae & Leucauge & 1.166666667 & 0 & 1.166666667 \\
\hline & & & & Tetragnatha & 1.636363636 & 0 & 1.636363636 \\
\hline & & Sheet Web Builder & Agelenidae & Agelenopsis & 1 & 0 & 1 \\
\hline & & & & Tegenaria & 1 & 0 & 1 \\
\hline & & & & Unknown & 0 & 3 & 2 \\
\hline & & Space Web Builder & Dictynidae & Cicurina & 1 & 0 & 1 \\
\hline & & & Pholcidae & Pholcus & 1.75 & 1 & 1.6 \\
\hline & & & Theridiidae & Enoplognatha & 1.625 & 0 & 1.625 \\
\hline & & & & Euryopsis & 1.666666667 & 0 & 1.666666667 \\
\hline & & & & Theridion & 1.416666667 & 1 & 1.384615385 \\
\hline & & Stalker & Mimetidae & Mimetus & 1 & 1 & 1 \\
\hline & & & Oxyopidae & Oxyopes & 1.133333333 & 2.291666667 & 1.846153846 \\
\hline & & & Salticidae & Eris & 1.954545455 & 1 & 1.84 \\
\hline & & & & Maevia & 0 & 1 & 1 \\
\hline & & & & Pellenes & 1 & 0 & 1 \\
\hline & & & & Phidippus & 1.176470588 & 1 & 1.166666667 \\
\hline & & & & Pholcus & 1 & 0 & 1 \\
\hline & & & & Sassacus & 1.592592593 & 1.461538462 & 1.528301887 \\
\hline & & & & Thiodina & 1.4 & 1.5 & 1.448275862 \\
\hline & & & & Unknown & 0 & 1.461538462 & 1.428571429 \\
\hline
\end{tabular}




\begin{tabular}{|c|c|c|c|c|c|c|c|}
\hline Trap Type & $\begin{array}{c}\text { Invasion } \\
\text { Status }\end{array}$ & $\begin{array}{c}\text { Functional } \\
\text { Guild }\end{array}$ & Family & Genus & $\begin{array}{l}\text { Mean } \\
\text { Adult }\end{array}$ & $\begin{array}{c}\text { Mean } \\
\text { Immature }\end{array}$ & $\begin{array}{c}\text { Mean } \\
\text { Abundance }\end{array}$ \\
\hline \multirow[t]{24}{*}{$\overline{\mathrm{SN}}$} & Invaded & בWandering Sheet Weaver & Linyphiidae & Agyneta & 1 & $\overline{0}$ & 1 \\
\hline & & & & Bathyphantes & 1.466666667 & 0 & 1.466666667 \\
\hline & & & & Drapestisca & 1 & 2.5 & 1.214285714 \\
\hline & & & & Drassyllus & 0 & 1 & 1 \\
\hline & & & & Neriene & 3 & 1 & 2 \\
\hline & & & & Unknown & 0 & 2.7 & 2.7 \\
\hline & Uninvaded & Ambusher & Philodromidae & Philodromus & 1.444444444 & 1.5 & 1.470588235 \\
\hline & & & & Tibellus & 0 & 1 & 1 \\
\hline & & & Pisauridae & Pisaurina & 1.347826087 & 1.823529412 & 1.55 \\
\hline & & & Thomisidae & Mecaphesa & 1 & 1.346153846 & 1.257142857 \\
\hline & & & & Micrathena & 1 & 0 & 1 \\
\hline & & & & Misomenoides & 1 & 1 & 1 \\
\hline & & & & Misumena & 1 & 1 & 1 \\
\hline & & & & Misumenops & 0 & 1 & 1 \\
\hline & & & & Tmarus & 0 & 1 & 1 \\
\hline & & & & Xysticus & 1 & 0 & 1 \\
\hline & & Folliage Runner & Clubionidae & Clubiona & 1.2 & 1.923076923 & 1.583333333 \\
\hline & & & & Unknown & 0 & 1 & 1 \\
\hline & & & Miturgidae & Cheiracanthium & 1 & 1 & 1 \\
\hline & & & & Unknown & 0 & 1.5 & 1.5 \\
\hline & & Ground Runner & Ctenidae & Anahita & 1 & 1 & 1 \\
\hline & & & Gnaphosidae & Drassyllus & 1.333333333 & 0 & 1.333333333 \\
\hline & & & & Gnaphosa & 1.333333333 & 1.5 & 1.363636364 \\
\hline & & & & Unknown & 0 & 2 & 1.5 \\
\hline
\end{tabular}




\begin{tabular}{|c|c|c|c|c|c|c|c|}
\hline Trap Type & $\begin{array}{c}\text { Invasion } \\
\text { Status }\end{array}$ & $\begin{array}{c}\text { Functional } \\
\text { Guild }\end{array}$ & Family & Genus & $\begin{array}{l}\text { Mean } \\
\text { Adult }\end{array}$ & $\begin{array}{c}\text { Mean } \\
\text { Immature }\end{array}$ & $\begin{array}{c}\text { Mean } \\
\text { Abundance }\end{array}$ \\
\hline \multirow[t]{26}{*}{ SN } & Uninvaded & Ground Runner & Lycosidae & Allocosa & 1 & 0 & 1 \\
\hline & & & & Hogna & 1 & 0 & 1 \\
\hline & & & & Pardosa & 1.25 & 1 & 1.2 \\
\hline & & & & Schizocosa & 1 & 0 & 1 \\
\hline & & & & Trebacosa & 2 & 0 & 2 \\
\hline & & & & Unknown & 0 & 2 & 2 \\
\hline & & Orb Weaver & Araneidae & Acanthepiera & 1 & 0 & 1 \\
\hline & & & & Araneus & 1.333333333 & 1 & 1.3125 \\
\hline & & & & Argiope & 0 & 4 & 4 \\
\hline & & & & Micrathena & 1.166666667 & 0 & 1.166666667 \\
\hline & & & & Unknown & 0 & 2 & 2 \\
\hline & & & & Zygiella & 1 & 0 & 1 \\
\hline & & & Tetragnathidae & Leucauge & 1.75 & 2 & 1.8 \\
\hline & & & & Tetragnatha & 1.666666667 & 1 & 1.571428571 \\
\hline & & Sheet Web Builder & Agelenidae & Agelenopsis & 1 & 0 & 1 \\
\hline & & & & Tegenaria & 1 & 1 & 1 \\
\hline & & Space Web Builder & Theridiidae & Enoplognatha & 1 & 0 & 1 \\
\hline & & & & Steatoda & 1 & 0 & 1 \\
\hline & & & & Theridion & 2.2 & 1.333333333 & 2 \\
\hline & & & & Thiodina & 4 & 0 & 4 \\
\hline & & & & Unknown & 0 & 0 & 1 \\
\hline & & Stalker & Oxyopidae & Oxyopes & 1 & 1.125 & 1.083333333 \\
\hline & & & Salticidae & Eris & 1.266666667 & 0 & 1.2666666667 \\
\hline & & & & Maevia & 1 & 0 & 1 \\
\hline & & & & Pellenes & 1 & 0 & 1 \\
\hline & & & & Phidippus & 1.222222222 & 1.333333333 & 1.25 \\
\hline
\end{tabular}




\begin{tabular}{|c|c|c|c|c|c|c|c|}
\hline Trap Type & $\begin{array}{c}\text { Invasion } \\
\text { Status }\end{array}$ & $\begin{array}{c}\text { Functional } \\
\text { Guild }\end{array}$ & Family & Genus & $\begin{array}{l}\text { Mean } \\
\text { Adult }\end{array}$ & $\begin{array}{c}\text { Mean } \\
\text { Immature }\end{array}$ & $\begin{array}{c}\text { Mean } \\
\text { Abundance }\end{array}$ \\
\hline \multirow[t]{9}{*}{$\mathrm{SN}$} & Uninvaded & Stalker & Salticidae & Sassacus & 1.210526316 & 1.222222222 & 1.214285714 \\
\hline & & & & Synemosyna & 1 & 0 & 1 \\
\hline & & & & Thiodina & 1.125 & 1 & 1.083333333 \\
\hline & & & & Unknown & 0 & 1.25 & 1.222222222 \\
\hline & & Wandering Sheet Weaver & Linyphiidae & Agyneta & 0 & 1.5 & 1.5 \\
\hline & & & & Bathyphantes & 1.375 & 1.25 & 1.35 \\
\hline & & & & Drapestisca & 1.375 & 1 & 1.333333333 \\
\hline & & & & Erigione & 1 & 0 & 1 \\
\hline & & & & Unknown & 0 & 1.625 & 1.625 \\
\hline
\end{tabular}


Appendix III: Mean abundance of arthropods collected May-October 2012 broken down by trap type, treatment [Control; $M v(+): M$. vimineum seed addition; $M v(-)$ : M. vimineum removal; $M v$ mono: $M$. vimineum monoculture], trophic group, functional guild, Order, morpho-group and family.

\begin{tabular}{|c|c|c|c|c|c|c|c|}
\hline $\begin{array}{l}\text { Trap } \\
\text { Type }\end{array}$ & Treatment & Trophic Group & Functional Guild & Order & Morpho-group & Family & $\begin{array}{c}\text { Mean } \\
\text { Abundance }\end{array}$ \\
\hline \multirow[t]{21}{*}{ PF } & Control & Carnivore & Parasite & Unknown & Mite & Mite & 1.00 \\
\hline & & & Parasitoid & Hymenoptera & Wasp & Pteromalidae & 1.00 \\
\hline & & & Predator & Chilopoda & Chilopod & Chilopoda & 1.00 \\
\hline & & & & Coleoptera & Beetle & Carabidae & 1.63 \\
\hline & & & & Hemiptera & Assassin Bug & Reduviiadae & 1.00 \\
\hline & & & & & Stinkbug & Pentatomidae & 1.00 \\
\hline & & & & Hymenoptera & Ant & Formicidae & 3.00 \\
\hline & & & & Opiliones & Harvestman & Phalangidae & 1.70 \\
\hline & & & & Unknown & Spider & Unknown & 1.74 \\
\hline & & Detritivore & Scavenger/Shredder & Archeognatha & Bristletail & Machilidae & 1.00 \\
\hline & & & & Blattodea & Cockroach & Blattellidae & 1.00 \\
\hline & & & & Collembola & Springtail & Entomobryidae & 2.77 \\
\hline & & & & & & Sminthuridae & 1.00 \\
\hline & & & & Diplopoda & Diplopod & Diplopoda & 1.00 \\
\hline & & & & Isopoda & Isopod & Isopod & 1.61 \\
\hline & & & & Orthoptera & Cricket & Rhaphidophoridae & 1.67 \\
\hline & & Herbivore & Free-living Chewer & Coleoptera & Beetle & Buprestidae & 1.00 \\
\hline & & & & & & Chrysomelidae & 1.00 \\
\hline & & & & & & Scarabeidae & 1.00 \\
\hline & & & & & Larva & Coleoptera Larva & 1.00 \\
\hline & & & & Lepidoptera & Larva & Lepidoptera Larva & 1.00 \\
\hline
\end{tabular}




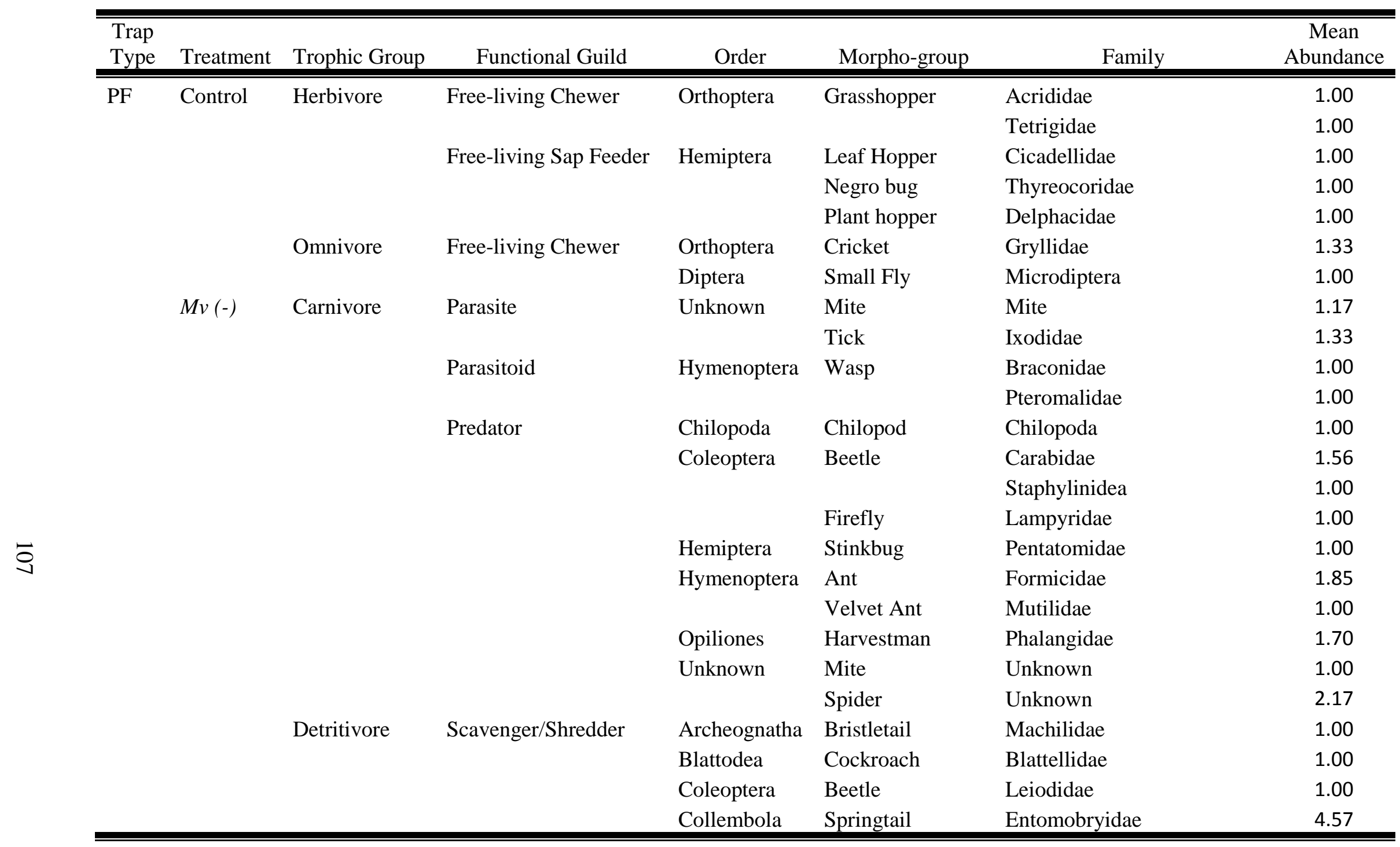




\begin{tabular}{|c|c|c|c|c|c|c|c|}
\hline $\begin{array}{l}\text { Trap } \\
\text { Type }\end{array}$ & Treatment & Trophic Group & Functional Guild & Order & Morpho-group & Family & $\begin{array}{c}\text { Mean } \\
\text { Abundance }\end{array}$ \\
\hline \multirow[t]{25}{*}{$\mathrm{PF}$} & $M v(-)$ & Detritivore & Scavenger/Shredder & Diplopoda & Diplopod & Diplopoda & 1.00 \\
\hline & & & & Isopoda & Isopod & Isopod & 2.06 \\
\hline & & & & Orthoptera & Cricket & Rhaphidophoridae & 1.00 \\
\hline & & & & Psocoptera & Barklice & Mesopsocidae & 1.00 \\
\hline & & Herbivore & Concealed Chewer & Coleoptera & Weevil & Curculionidae & 1.00 \\
\hline & & & Free-living Chewer & Coleoptera & Beetle & Chrysomelidae & 1.00 \\
\hline & & & & & & Scarabeidae & 6.50 \\
\hline & & & & Diptera & Midge & Mycetophilidae & 1.00 \\
\hline & & & & Hemiptera & Seed bug & Rhyparochromidae & 1.00 \\
\hline & & & & Lepidoptera & Larva & Lepidoptera Larva & 1.00 \\
\hline & & & & Orthoptera & Grasshopper & Acrididae & 1.00 \\
\hline & & & Free-living Sap Feeder & Hemiptera & Plant hopper & Delphacidae & 1.00 \\
\hline & & Omnivore & Free-living Chewer & Orthoptera & Cricket & Gryllidae & 1.89 \\
\hline & $M v(+)$ & Carnivore & Parasite & Unknown & Tick & Ixodidae & 2.00 \\
\hline & & & Parasitoid & Hymenoptera & Wasp & Pteromalidae & 1.00 \\
\hline & & & Predator & Coleoptera & Beetle & Carabidae & 1.63 \\
\hline & & & & Hemiptera & Stinkbug & Pentatomidae & 1.00 \\
\hline & & & & Hymenoptera & Ant & Formicidae & 2.10 \\
\hline & & & & & Velvet Ant & Mutilidae & 1.00 \\
\hline & & & & Opiliones & Harvestman & Phalangidae & 1.95 \\
\hline & & & & Unknown & Spider & Unknown & 1.85 \\
\hline & & Detritivore & Scavenger/Shredder & Archeognatha & Bristletail & Machilidae & 1.00 \\
\hline & & & & Blattodea & Cockroach & Blattellidae & 1.00 \\
\hline & & & & Coleoptera & Beetle & Tenebrionidae & 1.00 \\
\hline & & & & Collembola & Springtail & Entomobryidae & 3.13 \\
\hline
\end{tabular}




\begin{tabular}{|c|c|c|c|c|c|c|c|}
\hline $\begin{array}{l}\text { Trap } \\
\text { Type } \\
\end{array}$ & Treatment & Trophic Group & Functional Guild & Order & Morpho-group & Family & $\begin{array}{c}\text { Mean } \\
\text { Abundance }\end{array}$ \\
\hline \multirow[t]{25}{*}{$\mathrm{PF}$} & $M v(+)$ & Detritivore & Scavenger/Shredder & Diplopoda & Diplopod & Diplopoda & 1.00 \\
\hline & & & & Isopoda & Isopod & Isopod & 2.60 \\
\hline & & & & Orthoptera & Cricket & Rhaphidophoridae & 1.20 \\
\hline & & Herbivore & Free-living Chewer & Coleoptera & Beetle & Scarabeidae & 1.00 \\
\hline & & & & & Weevil & Bruchidae & 1.00 \\
\hline & & & & & Larva & Coleoptera Larva & 1.00 \\
\hline & & & & Lepidoptera & Larva & Lepidoptera Larva & 1.00 \\
\hline & & & & Orthoptera & Grasshopper & Acrididae & 1.00 \\
\hline & & & & & & Tetrigidae & 1.00 \\
\hline & & & Free-living Sap Feeder & Hemiptera & Aphid & Aphididae & 1.00 \\
\hline & & & & & Leaf Hopper & Cicadellidae & 1.00 \\
\hline & & & & & Plant hopper & Delphacidae & 1.00 \\
\hline & & & & & Whiteflies & Aleyrodidae & 1.00 \\
\hline & & Omnivore & Free-living Chewer & Orthoptera & Cricket & Gryllidae & 1.38 \\
\hline & Mv mono & Carnivore & Parasite & Unknown & Mite & Mite & 1.50 \\
\hline & & & & & Tick & Ixodidae & 1.00 \\
\hline & & & Parasitoid & Hymenoptera & Wasp & Tiphiidae & 1.00 \\
\hline & & & Predator & Coleoptera & Beetle & Carabidae & 1.25 \\
\hline & & & & & & Staphylinidea & 1.00 \\
\hline & & & & Hemiptera & Stinkbug & Pentatomidae & 1.00 \\
\hline & & & & Hymenoptera & Ant & Formicidae & 1.60 \\
\hline & & & & Opiliones & Harvestman & Phalangidae & 1.50 \\
\hline & & & & Unknown & Spider & Unknown & 2.30 \\
\hline & & Detritivore & Scavenger/Shredder & Archeognatha & Bristletail & Machilidae & 1.00 \\
\hline & & & & Collembola & Springtail & Entomobryidae & 3.96 \\
\hline
\end{tabular}




\begin{tabular}{|c|c|c|c|c|c|c|c|}
\hline $\begin{array}{l}\text { Trap } \\
\text { Type }\end{array}$ & Treatment & Trophic Group & Functional Guild & Order & Morpho-group & Family & $\begin{array}{c}\text { Mean } \\
\text { Abundance }\end{array}$ \\
\hline \multirow[t]{14}{*}{ PF } & \multirow[t]{14}{*}{ Mv mono } & \multirow[t]{2}{*}{ Detritivore } & \multirow[t]{2}{*}{ Scavenger/Shredder } & Isopoda & Isopod & Isopod & 1.42 \\
\hline & & & & Orthoptera & Cricket & Rhaphidophoridae & 1.00 \\
\hline & & \multirow[t]{11}{*}{ Herbivore } & Concealed Chewer & Coleoptera & Weevil & Curculionidae & 1.00 \\
\hline & & & \multirow[t]{7}{*}{ Free-living Chewer } & \multirow[t]{5}{*}{ Coleoptera } & \multirow[t]{3}{*}{ Beetle } & Buprestidae & 1.00 \\
\hline & & & & & & Elateridae & 1.00 \\
\hline & & & & & & Scarabeidae & 6.50 \\
\hline & & & & & Larva & Carabidae Larva & 1.00 \\
\hline & & & & & Weevil & Bruchidae & 1.00 \\
\hline & & & & Hymenoptera & Sawfly & Tenthredinidae & 1.00 \\
\hline & & & & Lepidoptera & Larva & Lepidoptera Larva & 1.00 \\
\hline & & & \multirow[t]{3}{*}{ Free-living Sap Feeder } & \multirow[t]{3}{*}{ Hemiptera } & Aphid & Aphididae & 1.00 \\
\hline & & & & & Leaf Hopper & Cicadellidae & 1.00 \\
\hline & & & & & Spittle bug & Cercopidae & 1.00 \\
\hline & & Omnivore & Free-living Chewer & Orthoptera & Cricket & Gryllidae & 2.78 \\
\hline $\mathrm{SN}$ & \multirow[t]{11}{*}{ Control } & \multirow[t]{11}{*}{ Carnivore } & \multirow[t]{2}{*}{ Parasite } & Diptera & Mosquito & Culicidae & 1.00 \\
\hline & & & & Hymenoptera & Wasp & Eupelmidae & 1.00 \\
\hline & & & \multirow[t]{6}{*}{ Parasitoid } & \multirow[t]{6}{*}{ Hymenoptera } & \multirow[t]{6}{*}{ Wasp } & Braconidae & 3.00 \\
\hline & & & & & & Chrysididae & 1.00 \\
\hline & & & & & & Cynipidae & 1.00 \\
\hline & & & & & & Encyrtidae & 1.00 \\
\hline & & & & & & Ichneumonidae & 1.00 \\
\hline & & & & & & Pteromalidae & 1.67 \\
\hline & & & \multirow[t]{3}{*}{ Predator } & \multirow[t]{2}{*}{ Coleoptera } & Beetle & Carabidae & 1.00 \\
\hline & & & & & Firefly & Lampyridae & 1.00 \\
\hline & & & & Hemiptera & Ambush Bug & Phymatidae & 1.00 \\
\hline
\end{tabular}




\begin{tabular}{|c|c|c|c|c|c|c|c|}
\hline $\begin{array}{l}\text { Trap } \\
\text { Type }\end{array}$ & Treatment & Trophic Group & Functional Guild & Order & Morpho-group & Family & $\begin{array}{c}\text { Mean } \\
\text { Abundance }\end{array}$ \\
\hline \multirow[t]{24}{*}{ SN } & Control & Carnivore & Predator & Hemiptera & Assassin Bug & Reduviiadae & 1.44 \\
\hline & & & & & Stinkbug & Pentatomidae & 1.50 \\
\hline & & & & Hymenoptera & Ant & Formicidae & 1.50 \\
\hline & & & & & Wasp & Crabrionidae & 1.00 \\
\hline & & & & & & Sphecidae & 1.00 \\
\hline & & & & Opiliones & Harvestman & Phalangidae & 2.00 \\
\hline & & & & Orthoptera & Katydid & Tettigonidae & 1.33 \\
\hline & & & & Unknown & Spider & Unknown & 2.16 \\
\hline & & Detritivore & Scavenger/Shredder & Coleoptera & Beetle & Leiodidae & 1.00 \\
\hline & & & & Collembola & Springtail & Entomobryidae & 1.00 \\
\hline & & & & Psocoptera & Barklice & Peripsocidae & 1.00 \\
\hline & & Herbivore & Concealed Chewer & Coleoptera & Weevil & Curculionidae & 1.00 \\
\hline & & & Free-living Chewer & Coleoptera & Beetle & Chrysomelidae & 1.14 \\
\hline & & & & & & Mordellidae & 1.00 \\
\hline & & & & & & Ptilodactylidae & 1.00 \\
\hline & & & & & Larva & Coleoptera Larva & 1.00 \\
\hline & & & & & Weevil & Bruchidae & 1.00 \\
\hline & & & & Hemiptera & Seed bug & Pachygronthidae & 1.00 \\
\hline & & & & & & Rhyparochromidae & 1.67 \\
\hline & & & & Lepidoptera & Larva & $\begin{array}{l}\text { Lepidoptera Larva } \\
\text { Unknown }\end{array}$ & 1.00 \\
\hline & & & & & & Microlepidopteran & 1.00 \\
\hline & & & & Orthoptera & Grasshopper & Acrididae & 1.73 \\
\hline & & & & & & Tetrigidae & 2.00 \\
\hline & & & Free-living Sap Feeder & Hemiptera & Aphid & Aphididae & 3.20 \\
\hline
\end{tabular}




\begin{tabular}{|c|c|c|c|c|c|c|c|}
\hline $\begin{array}{l}\text { Trap } \\
\text { Type }\end{array}$ & Treatment & Trophic Group & Functional Guild & Order & Morpho-group & Family & $\begin{array}{c}\text { Mean } \\
\text { Abundance }\end{array}$ \\
\hline \multirow[t]{25}{*}{$\mathrm{SN}$} & Control & Herbivore & Free-living Sap Feeder & Hemiptera & Leaf Hopper & Cicadellidae & 4.56 \\
\hline & & & & & Negro bug & Thyreocoridae & 1.00 \\
\hline & & & & & Plant hopper & Delphacidae & 4.46 \\
\hline & & & & & & Derbidae & 1.00 \\
\hline & & & & & Spittle bug & Cercopidae & 1.55 \\
\hline & & & & & Squash Bug & Coreidae & 1.00 \\
\hline & & Omnivore & Free-living Chewer & Orthoptera & Cricket & Gryllidae & 1.00 \\
\hline & & & & Diptera & Large Fly & Macrodiptera & 1.30 \\
\hline & & & & & Small Fly & Microdiptera & 1.65 \\
\hline & $M v(-)$ & Carnivore & Parasite & Diptera & Mosquito & Culicidae & 1.00 \\
\hline & & & Parasitoid & Hymenoptera & Wasp & Braconidae & 1.89 \\
\hline & & & & & & Chrysididae & 1.00 \\
\hline & & & & & & Cynipidae & 1.00 \\
\hline & & & & & & Diapriidae & 1.33 \\
\hline & & & & & & Encyrtidae & 1.00 \\
\hline & & & & & & Pteromalidae & 1.00 \\
\hline & & & & & & Torymidae & 1.00 \\
\hline & & & Predator & Coleoptera & Beetle & Coccinellidae & 1.00 \\
\hline & & & & Hemiptera & Assassin Bug & Reduviiadae & 1.00 \\
\hline & & & & & Stinkbug & Pentatomidae & 1.00 \\
\hline & & & & Hymenoptera & Ant & Formicidae & 1.67 \\
\hline & & & & Opiliones & Harvestman & Phalangidae & 1.00 \\
\hline & & & & Orthoptera & Katydid & Tettigonidae & 1.25 \\
\hline & & & & Unknown & Spider & Unknown & 1.78 \\
\hline & & Detritivore & Free-living Chewer & Hymenoptera & Sawfly & Tenebrionidae & 1.00 \\
\hline
\end{tabular}




\begin{tabular}{|c|c|c|c|c|c|c|c|}
\hline $\begin{array}{l}\text { Trap } \\
\text { Type }\end{array}$ & Treatment & Trophic Group & Functional Guild & Order & Morpho-group & Family & $\begin{array}{c}\text { Mean } \\
\text { Abundance }\end{array}$ \\
\hline \multirow[t]{23}{*}{$\mathrm{SN}$} & $M v(-)$ & Detritivore & Scavenger/Shredder & Coleoptera & Beetle & Leiodidae & 1.00 \\
\hline & & & & & & Tenebrionidae & 1.00 \\
\hline & & & & Collembola & Springtail & Entomobryidae & 2.00 \\
\hline & & & & Psocoptera & Barklice & Peripsocidae & 1.00 \\
\hline & & & & & & Psocidae & 1.00 \\
\hline & & Herbivore & Free-living Chewer & Coleoptera & Beetle & Chrysomelidae & 1.17 \\
\hline & & & & & & Mordellidae & 1.00 \\
\hline & & & & & & Ptilodactylidae & 1.00 \\
\hline & & & & & Larva & Unknown Coleoptera & 1.00 \\
\hline & & & & Diptera & Crane Fly & Tipulidae & 1.00 \\
\hline & & & & Hemiptera & Seed bug & Rhyparochromidae & 2.00 \\
\hline & & & & Hymenoptera & Sawfly & Tenthredinidae & 1.00 \\
\hline & & & & Orthoptera & Grasshopper & Acrididae & 1.29 \\
\hline & & & & & & Tetrigidae & 1.00 \\
\hline & & & Free-living Sap Feeder & Hemiptera & Aphid & Aphididae & 1.00 \\
\hline & & & & & Leaf Hopper & Cicadellidae & 3.29 \\
\hline & & & & & Negro bug & Thyreocoridae & 1.00 \\
\hline & & & & & Plant hopper & Delphacidae & 4.07 \\
\hline & & & & & & Derbidae & 1.00 \\
\hline & & & & & Spittle bug & Cercopidae & 1.13 \\
\hline & & & & & Whiteflies & $\begin{array}{l}\text { Aleyrodidae } \\
\text { Unknown }\end{array}$ & 1.00 \\
\hline & & & Unknown & Lepidoptera & Larva & Microlepidopteran & 1.00 \\
\hline & & Omnivore & Free-living Chewer & Orthoptera & Cricket & Gryllidae & 1.00 \\
\hline & & & & Diptera & Large Fly & Macrodiptera & 2.00 \\
\hline
\end{tabular}




\begin{tabular}{|c|c|c|c|c|c|c|c|}
\hline $\begin{array}{l}\text { Trap } \\
\text { Type }\end{array}$ & Treatment & Trophic Group & Functional Guild & Order & Morpho-group & Family & $\begin{array}{c}\text { Mean } \\
\text { Abundance }\end{array}$ \\
\hline \multirow[t]{25}{*}{ SN } & $M v(-)$ & Omnivore & Free-living Chewer & Diptera & Small Fly & Microdiptera & 3.00 \\
\hline & $M v(+)$ & Carnivore & Parasite & Diptera & Mosquito & Culicidae & 1.25 \\
\hline & & & Parasitoid & Hymenoptera & Wasp & Braconidae & 1.21 \\
\hline & & & & & & Chrysididae & 1.20 \\
\hline & & & & & & Cynipidae & 1.00 \\
\hline & & & & & & Diapriidae & 1.67 \\
\hline & & & & & & Encyrtidae & 1.00 \\
\hline & & & & & & Eupelmidae & 1.00 \\
\hline & & & & & & Ichneumonidae & 1.00 \\
\hline & & & & & & Pteromalidae & 1.17 \\
\hline & & & Predator & Coleoptera & Beetle & Cleridae & 1.00 \\
\hline & & & & & & Histeridae & 1.00 \\
\hline & & & & Hemiptera & Assassin Bug & Reduviiadae & 1.00 \\
\hline & & & & & Stinkbug & Pentatomidae & 1.00 \\
\hline & & & & Hymenoptera & Ant & Formicidae & 1.81 \\
\hline & & & & Mantodea & Mantis & Mantidae & 1.00 \\
\hline & & & & Opiliones & Harvestman & Phalangidae & 2.00 \\
\hline & & & & Orthoptera & Katydid & Tettigonidae & 1.43 \\
\hline & & & & Unknown & Spider & Unknown & 3.22 \\
\hline & & Detritivore & Scavenger/Shredder & Coleoptera & Beetle & Leiodidae & 1.00 \\
\hline & & & & & & Tenebrionidae & 1.00 \\
\hline & & & & Collembola & Springtail & Entomobryidae & 3.80 \\
\hline & & & & Orthoptera & Cricket & Rhaphidophoridae & 1.00 \\
\hline & & & & Psocoptera & Barklice & Peripsocidae & 1.00 \\
\hline & & Herbivore & Concealed Chewer & Coleoptera & Weevil & Curculionidae & 1.00 \\
\hline
\end{tabular}




\begin{tabular}{|c|c|c|c|c|c|c|c|}
\hline $\begin{array}{l}\text { Trap } \\
\text { Type } \\
\end{array}$ & Treatment & Trophic Group & Functional Guild & Order & Morpho-group & Family & $\begin{array}{c}\text { Mean } \\
\text { Abundance } \\
\end{array}$ \\
\hline \multirow[t]{25}{*}{$\mathrm{SN}$} & $M v(+)$ & Herbivore & Free-living Chewer & Coleoptera & Beetle & Chrysomelidae & 1.22 \\
\hline & & & & & & Mordellidae & 1.00 \\
\hline & & & & & Weevil & Bruchidae & 1.00 \\
\hline & & & & Hemiptera & Seed bug & Rhyparochromidae & 1.20 \\
\hline & & & & Lepidoptera & Larva & Lepidoptera Larva & 1.00 \\
\hline & & & & Orthoptera & Grasshopper & Acrididae & 1.32 \\
\hline & & & Free-living Sap Feeder & Hemiptera & Aphid & Aphididae & 1.00 \\
\hline & & & & & Leaf Hopper & Cicadellidae & 7.11 \\
\hline & & & & & & Delphacidae & 2.00 \\
\hline & & & & & Negro bug & Thyreocoridae & 1.00 \\
\hline & & & & & Plant hopper & Delphacidae & 5.67 \\
\hline & & & & & & Derbidae & 1.00 \\
\hline & & & & & & Issidae & 1.00 \\
\hline & & & & & Spittle bug & Cercopidae & 1.79 \\
\hline & & & & & & Hymenoptera & 1.00 \\
\hline & & & & Lepidoptera & Moth & Microlepidoptera & 1.00 \\
\hline & & & & Thysanoptera & Thrips & Paleothripidae & 1.00 \\
\hline & & & & & & Thripidae & 1.00 \\
\hline & & Omnivore & Free-living Chewer & Orthoptera & Cricket & Gryllidae & 1.13 \\
\hline & & & & Diptera & Large Fly & Macrodiptera & 1.00 \\
\hline & & & & & Small Fly & Microdiptera & 2.37 \\
\hline & Mv mono & Carnivore & Parasite & Diptera & Mosquito & Culicidae & 1.00 \\
\hline & & & & Unknown & Mite & Mite & 1.00 \\
\hline & & & & & Tick & Ixodidae & 1.00 \\
\hline & & & Parasitoid & Hymenoptera & Wasp & Braconidae & 1.00 \\
\hline
\end{tabular}




\begin{tabular}{|c|c|c|c|c|c|c|c|}
\hline $\begin{array}{l}\text { Trap } \\
\text { Type }\end{array}$ & Treatment & Trophic Group & Functional Guild & Order & Morpho-group & Family & $\begin{array}{c}\text { Mean } \\
\text { Abundance }\end{array}$ \\
\hline \multirow[t]{24}{*}{ SN } & Mv mono & Carnivore & Parasitoid & Hymenoptera & Wasp & Chrysididae & 1.00 \\
\hline & & & & & & Cynipidae & 1.00 \\
\hline & & & & & & Diapriidae & 1.00 \\
\hline & & & & & & Ichneumonidae & 1.00 \\
\hline & & & Predator & Coleoptera & Firefly & Lampyridae & 1.00 \\
\hline & & & & Hemiptera & Ambush Bug & Phymatidae & 1.00 \\
\hline & & & & Hymenoptera & Ant & Formicidae & 1.00 \\
\hline & & & & Opiliones & Harvestman & Phalangidae & 1.00 \\
\hline & & & & Orthoptera & Katydid & Tettigonidae & 1.00 \\
\hline & & & & Unknown & Spider & Unknown & 1.55 \\
\hline & & Detritivore & Scavenger/Shredder & Coleoptera & Beetle & Leiodidae & 1.00 \\
\hline & & & & Collembola & Springtail & Entomobryidae & 1.17 \\
\hline & & Herbivore & Free-living Chewer & Coleoptera & Beetle & Chrysomelidae & 1.00 \\
\hline & & & & & Weevil & Bruchidae & 1.00 \\
\hline & & & & Lepidoptera & Larva & $\begin{array}{l}\text { Lepidoptera Larva } \\
\text { Unknown }\end{array}$ & 1.00 \\
\hline & & & & & Microlepidoptera & Microlepidopteran & 1.00 \\
\hline & & & & Orthoptera & Grasshopper & Acrididae & 1.46 \\
\hline & & & & & & Tetrigidae & 2.00 \\
\hline & & & Free-living Sap Feeder & Hemiptera & Aphid & Aphididae & 1.33 \\
\hline & & & & & Leaf Hopper & Caliscellidae & 1.00 \\
\hline & & & & & & Cicadellidae & 3.00 \\
\hline & & & & & Plant hopper & Delphacidae & 2.86 \\
\hline & & & & & & Derbidae & 1.00 \\
\hline & & & & & Spittle bug & Cercopidae & 1.00 \\
\hline
\end{tabular}




\begin{tabular}{llllllll}
\hline \hline $\begin{array}{c}\text { Trap } \\
\text { Type }\end{array}$ & Treatment & Trophic Group & Functional Guild & Order & Morpho-group & Mean \\
\hline \hline SN & Mv mono & Herbivore & Free-living Sap Feeder & Thysanoptera & Thrips & Thripidae & Abundance \\
& & Omnivore & Free-living Chewer & Orthoptera & Cricket & Gryllidae & 1.00 \\
& & & & Diptera & Large Fly & Macrodiptera & 1.00 \\
& & & & Small Fly & Microdiptera & 1.00 \\
\hline \hline
\end{tabular}




\section{CURRICULUM VITAE}

Judith L. Metcalf

3409 Rowena Rd \#3, Louisville KY 40218

\section{EDUCATION}

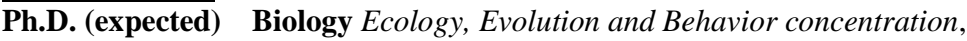
University of Louisville, Louisville, KY GPA: 3.763

M.S. Biology Texas A\&M University-Corpus Christi, Corpus Christi, TX

B.S. Biology University of Louisville, Louisville, KY e-mail: metcalf.judy@gmail.com phone: (502) 419-2859

\section{$\underline{\text { Research Interests: }}$}

My primary research interest is in community ecology and conservation, primarily the impacts of urbanization and human activities on natural communities. My current work focuses on the role of terrestrial plants on arthropod community structure and food web control. Other related interests include the role of human activity on overwintering and migrating shorebirds.

\section{$\underline{\text { Research Experience }}$}

Community level impacts of Microstegium vimineum on arthropods in a temperate

deciduous forest

Dissertation

University of Louisville, Department of Biology

Major Advisor: Dr. Sarah Emery, Professor, University of Louisville, Department of Biology

Playa Lakes Joint Venture Shorebird Survey

USGS Fort Collins, CO

Primary Supervisor: Dr. Susan Skagen, U.S. Geological Survey, Fort Collins, CO

Community composition and behavior of birds on South Texas Coastal Beaches: A comparison of driving and non-driving treatments

Thesis

Texas A\&M University - Corpus Christi

Primary Supervisor: Dr. Kim Withers, Research Scientist, Center for Coastal Studies

Texas A\&M University-Corpus Christi

\section{TEACHING EXPERIENCE}

\section{Teaching Assistant}

Biol 262 - Human Anatomy \& Physiology Lab

A study and correlation between the anatomy and physiology of selected organ systems.

University of Louisville, Department of Biology

- $\quad$ Ran laboratory activities for weekly class meetings for 1-2 sections/wk for approximately students 30 students/section

- Graded handouts, quizzes, and exams.

- $\quad$ Assisted students one-on-one as needed. 


\section{TEACHING EXPERIENCE (cont'd)}

Teaching Assistant

Principles of Biology Laboratory - University of Louisville

Department of Biology

A comprehensive laboratory in Biology involving experiments at the cellular/genetics level

through organismic diversity. An emphasis is placed on critical analysis of scientific data

through application of the scientific method.

University of Louisville, Department of Biology

- Ran laboratory activities for twice weekly class meetings for 1-3 sections/semester for approximately 30 students/section

- $\quad$ Graded handouts, quizzes and exams

- Assisted in lab set up and breakdown

- Assisted students one-on-one as needed

Laboratory for Introduction to Biological Systems - University of Louisville

Fall 2009, Fall 2010

Department of Biology

Survey of biology including an introduction to biological molecules, ecology, and genetics.

- Ran laboratory activities for weekly class meetings for approximately 130 students.

- Wrote and graded handouts, quizzes, and exams

- Graded weekly lab reports

- Assisted students one-on-one as needed.

Biology I Laboratory - Texas A\&M University-Corpus Christ

Department of Biology

Presentation of basic biological concepts including scientific method, cytology, energetics, nucleic acids and genetics.

- Ran laboratory activities for twice weekly class meetings for 2-3 sections/semester for approximately 30 students/section

- $\quad$ Graded handouts, quizzes and exams

- $\quad$ Assisted in lab set up and breakdown

- Assisted students one-on-one as needed

Biology II Laboratory - Texas A\&M University-Corpus Christi

Summer 2006, 2007

Department of Biology

This course is an overview of the major concepts in biological diversity and plant and animal biology.

Laboratory work will include individual/team activities as well as technology-related assignments

- Ran laboratory activities for twice weekly class meetings for 2-3 sections/semester for approximately 30 students/section

- Graded handouts, quizzes and exams

- $\quad$ Assisted in lab set up and breakdown

- $\quad$ Assisted students one-on-one as needed

Botany Laboratory - Texas A\&M University - Corpus Christi

Fall 2006, Fall 2007

Department of Biology

This course is an overview of plant form and function for Education students.

- Created laboratory activities and wrote lab manual for future botany lab instructors

- Ran laboratory activities for weekly class meetings for 1 sections/semester for approximately 30 students/section

- $\quad$ Graded handouts, quizzes and exams

- Assisted in lab set up and breakdown

- Assisted students one-on-one as needed 


\section{ADDITIONAL TEACHING ACTIVITIES}

\section{Guest Lecturer}

Fall 2013

BIOL 563 - Population and Community Ecology

University of Louisville, Department of Biology

- Guest lectured for one class period

- Food webs and trophic dynamics

\section{FELLOWSHIPS AND GRANTS:}

- Dissertation Completion Award (University of Louisville - Fall 2013) - Monthly stipend/tuition/insurance

- Marcia Athey Grant, (Kentucky Academy of Sciences - May 2011-Oct 2012) $\$ 3000$

- College of Arts \& Sciences Deans office Grant (University of Louisville, 2010) $\$ 500$

- Hans \& Patricia Suter Endowment Grant (Center for Coastal Studies, Texas A\&M University Corpus Christi - 2006)

- Science \& Technology Scholarship (Texas A\&M University-Corpus Christi-2006) \$600

- Undergraduate Research Grant (University of Louisville - 2004)

\section{POSTERS AND PRESENTATIONS}

Metcalf, JL, Ecological Society of America 2013 Annual Meeting: Arthropod community structure in the presence of Microstegium vimineum. Minneapolis, MN

Metcalf, JL, UofL Department of Biology 2012 Awards Day: Arthropod community structure in the presence of Microstegium vimineum. Louisville, KY

Metcalf, JL, UofL 2011 Graduate Research Symposium: Arthropod community structure in the presence of Microstegium vimineum. Louisville, KY

Metcalf, JL, Ecological Society of America 2010 Annual Meeting, Poster Presentation: Increased arthropod abundance and diversity in Microstegium vimineum invasions, Pittsburgh, PA

Metcalf, JL, Association of Field Ornithologists 2007 Annual Meeting: Does unrestricted vehicle access on beaches disturb shorebirds on the central Texas gulf coast?. Bangor, ME 